\title{
Biopolitical Cyborgs in Post-1980 North American Critical Dystopias
}

Valerie Ann Surrett

Follow this and additional works at: https://researchrepository.wvu.edu/etd

\section{Recommended Citation}

Surrett, Valerie Ann, "Biopolitical Cyborgs in Post-1980 North American Critical Dystopias" (2017). Graduate Theses, Dissertations, and Problem Reports. 6747.

https://researchrepository.wvu.edu/etd/6747

This Dissertation is protected by copyright and/or related rights. It has been brought to you by the The Research Repository @ WVU with permission from the rights-holder(s). You are free to use this Dissertation in any way that is permitted by the copyright and related rights legislation that applies to your use. For other uses you must obtain permission from the rights-holder(s) directly, unless additional rights are indicated by a Creative Commons license in the record and/ or on the work itself. This Dissertation has been accepted for inclusion in WVU Graduate Theses, Dissertations, and Problem Reports collection by an authorized administrator of The Research Repository @ WVU.

For more information, please contact researchrepository@mail.wvu.edu. 


\title{
Biopolitical Cyborgs in Post-1980 North American Critical Dystopias
}

\author{
Valerie Ann Surrett \\ Dissertation submitted \\ to the Eberly College of Arts and Sciences \\ at West Virginia University \\ in partial fulfillment of the requirements for the degree of \\ Doctor of Philosophy in \\ English \\ Kathleen Ryan, Ph.D., Chair \\ Rosemary Hathaway, Ph.D. \\ Gwen Bergner, Ph.D. \\ Michael Germana, Ph.D. \\ Lisa Yaszek, Ph.D. \\ Department of English
}

Morgantown, West Virginia

2017

Keywords: cyborgs, posthumanism, biopolitics, critical dystopias, reproductive medicine, genetic engineering, utopianism

Copyright 2017 Valerie Ann Surrett 


\title{
ABSTRACT \\ Biopolitical Cyborgs in Post-1980 North American Critical Dystopias
}

\author{
Valerie Ann Surrett
}

Stories of babies born from transplanted uteruses, fetuses created from three biological parents, a booming global surrogacy market, and embryonic gene selection have all made national headlines in the past two years. We live in an era of science fictional childbirths. Reproductive technologies that didn't exist a decade ago are now peddled to whomever can afford them, and science fiction has responded. Post-1980 speculative fiction confronts a potent convergence of various sociopolitical and reproductive trends, including the rise of neoliberal conservatism; the "test tube baby" boom; polarized reproductive rights debates; and Diamond $v$. Chakrabarty (1980), the Supreme Court decision granting corporations the ability to patent genetically modified life forms.

In North American dystopian fiction written after 1980, anxieties about technological reproduction manifest in metaphorical figures I term "biopolitical cyborgs." Evocative of Aldous Huxley's vision of a brave new world, biopolitical cyborgs are citizens whose hybrid features are designed to hinder political agency and personal autonomy. My project reads the biopolitical cyborg as a metaphor of the myriad ways life processes are governed in liberal democracies. I argue that these hybrid denizens of posthuman futures forecast the potential for powerful states and corporations to wield biomedical technologies in their favor, essentially creating citizens designed to comply with state agendas. However, the open and ambiguous endings characteristic of the critical-dystopian genre infuse these dystopian figures with eutopian glimmers, opening possibilities for biopolitical cyborgs to learn to use their hybridity to work towards a posthuman ironic liberation.

Each chapter of my dissertation explores one of four manifestations of this complex figure. Margaret Atwood's The Handmaid's Tale, a dire account of an authoritarian state gaining control of women's fertility, introduces the figure of Mother-soldiers. Mother-soldiers are female citizens who, locked in biopolitical wars, are transformed into soldiers and coerced to use their reproductive abilities in wars for the future of the nation. Soldier-cyborgs, such as the Community citizens in Lois Lowry's The Giver, are genetically modified or artificially augmented humans. In essence, the state uses genetic modification to create perfect, subservient citizens. Bare-life-cyborgs, such as the New People of Paolo Bacigalupi's The Windup Girl, are human/nonhuman hybrids whose transgenic DNA places them outside the protections of human rights laws. Bare-life-cyborgs forecast using the patenting of hybrid life forms to bypass constitutional protections, allowing corporations to legally create and sell a slave class within liberal democracies. Finally, I have termed future posthuman generations born to cyborgs as Lilith's-children. Exemplified by the human/alien hybrids in Octavia Butler's Xenogenesis trilogy, these novels feature a post-apocalyptic earth where only a modified human can survive. As posthumans, Lilith's-children have the potential to move beyond dualistic gender, race, and class hierarchies. 


\section{ACKNOWLEDGMENTS}

To Katy Ryan, my mentor, chair, and friend, who has gently guided me through so much more than this dissertation. Thank you for showing me so many ways to make my work matter.

To Rosemary Hathaway, who, in addition to offering valuable feedback throughout this process, has graciously met me for countless coffees and lunches and allowed me to say all the things I'm not supposed to say out loud. Thank you.

To Gwen Bergner, who pushes me to be a better writer, not just a better thinker. Thank you. And thank you for that one email about life during a dissertation fellowship that made me feel way less crazy and far from alone.

To Michael Germana, who demands little, praises often, and has a knack for pointing out crucial moments I've overlooked. Thank you.

To Lisa Yaszek, who generously agreed to take an active role in guiding a project for a woman she's never met. I cannot thank you enough for lending me your expertise and for encouraging me, early on, that "there is no need to be afraid of theory-you can do a lot more damage to it than it can do to you. I promise!"

To the men in the book club at FCI Hazelton, the men who have become my friends. Thank you for showing me the necessity of finding solutions. Thank you for changing how I think. You've impacted this project more than you know. Getting to know you has been one of the greatest honors of my life.

To my mother and father-in-law, Mike and Caron, who check on me often and ask real, meaningful questions about my ideas and my work. Thank you for making my interests your interests.

To my parents, Alan and Desiree. Thank you for your unwavering support. Thank you for telling me that you are proud of me and for expressing your full confidence that I could do this. And thank you for dropping everything to come to West Virginia to take care of your grandchildren during the final weeks of this process - for cooking real food with green stuff, for tackling our mountain of laundry, and for doing so much for me when I couldn't do it all.

To my husband, Derrick, my person. Thank you for your endless patience with and enthusiasm for this process. Thank you for moving to West Virginia with me without hesitation and without complaint. Thank you for working overtime to compensate for my TA stipend. Thank you for listening to three years worth of late-night jibber jabber about cyborgs, childbirth, and aliens. Thank you for knowing exactly what I need when I'm too tired to ask, whether its bringing home pizza and wine or texting video montages of animals sneezing. And thank you for your tireless, sincere belief in me. You are my constant.

To my children, Liam and Norah, who were born during this process. You are my greatest sources of motivation and my biggest distractions. Thank you for forcing me to stop 
writing to go play outside, sing silly songs, or read Chugga Chugga Choo-choo. Thank you for keeping me grounded, for making me laugh, and for reminding me daily of the real-life stakes of eutopian dreams. This is for you. 


\section{Table of Contents}

$\begin{array}{lr}\text { Introduction } & 1\end{array}$

Biopolitical Cyborgs in Post-1980 North American Critical Dystopias

\section{Chapter 1}

Four Figures of Biopolitical Cyborgs

Chapter 2

Mother-Soldiers in Margaret Atwood's 1985 The Handmaid's Tale

\section{Chapter 3}

Soldier-Cyborgs in Lois Lowry's 1993 The Giver

\section{Chapter 4}

Bare-life-cyborgs in Paolo Bacigalupi's 2009 The Windup Girl

\section{Chapter 5}

Lilith's-Children in Octavia Butler's 1987-89 Xenogenesis Trilogy

\section{Epilogue}

This is Not a Conclusion 
Introduction

Biopolitical Cyborgs in Post-1980 North American Critical Dystopias

A few years ago, amid a cultural and political shift toward STEM disciplines in higher ed, a science vs. humanities themed internet meme made its rounds through social media newsfeeds. The meme's top portion features an illustration of a middle-aged white man, donning dark-rimmed glasses and a white lab coat, throwing his hands in the air in celebration as he watches a giant egg beginning to hatch. The image is accompanied by the text, "Science can tell you how to clone a Tyrannosaurus Rex." Below this scene is a second illustration depicting our pioneering, but fatally shortsighted scientist now fleeing his hungry progeny, captioned, "Humanities can tell you why this might be a bad idea." The meme's witty jibe differentiates between scientific progress and social progress by insinuating that academia's bourgeoning STEM myopia could set society on a course towards self-destruction. Only the humanities can save science from itself by tempering technological advancements through considerations of the social, economic, and political imperatives driving their development. The meme's bloodthirsty TRex, bent on devouring its maker, captures the essence of ethical debates surrounding the development of technologies capable of taking and creating life-just because you can doesn't mean you should - while also linking the making of life to the taking of life in a circular, causeand-effect loop.

I begin my introduction to biopolitical cyborgs with this dystopian tableau of science gone awry because it gets to the heart of so many depictions of cyborganization in critical dystopias. Stories of babies born from transplanted uteruses, fetuses created from three biological parents, a booming global surrogacy market, and embryonic gene selection have all made national headlines in the past two years. We live in an era of science fictional childbirths. 
Reproductive technologies that didn't exist a decade ago are now peddled to whomever can afford them, and critical dystopias have responded. While biomedical and bioengineering technologies are actively pursued by many science disciplines for their potential to assist in the creation and increased longevity of human life, these novels interject warnings of ways the uncritical implementation of biomedical discoveries could ultimately undermine their intended purposes. Cyborg images in critical dystopias overwhelmingly speculate that the merger of human and machine will initially yield dystopian results of hindered personal and political agency despite the potentials for cyborganization to enhance human ability and health. While it is tempting to attribute such speculations to an irrational distrust of science or a reactionary impulse to preserve "natural" life processes, i.e., warnings against "playing God," these authors place the blame for science's negative consequences on the power systems that produce and implement biotechnologies rather than on the technologies themselves.

In North American dystopian fiction written after 1980, anxieties about technological reproduction manifest in metaphorical figures I term "biopolitical cyborgs." Evocative of Aldous Huxley's vision of a brave new world, biopolitical cyborgs are citizens whose hybrid features are designed to hinder human ability and agency. My dissertation identifies four types of cyborg figures in four post-1980 critical-dystopian novels. Perhaps the most well known of the novels in my study is Margaret Atwood's 1985 The Handmaid's Tale, a dire account of an authoritarian state gaining control of women's fertility. This novel introduces the figure of Mother-soldiers, female citizens who, locked in biopolitical wars, are transformed into soldiers. A familiar figure in dystopian novels, mother-soldiers are coerced to use their reproductive abilities in wars for the future of the nation. Soldier-cyborgs, such as the Community citizens in Lois Lowry's 1993 The Giver, are genetically modified or artificially augmented humans. In essence, the state uses 
genetic modification to create perfect, subservient citizens. Bare-life-cyborgs, such as the New People of Paolo Bacigalupi's 2009 The Windup Girl, are human/nonhuman hybrids whose transgenic DNA places them outside the protections of human rights laws. Bare-life-cyborgs forecast the patenting of hybrid life forms to bypass constitutional protections, allowing corporations to legally create and sell a slave class within liberal democracies. Finally, I have termed future posthuman generations born to cyborgs as Lilith's-children. Exemplified by Octavia Butler's human/alien hybrids in her 1987-89 Xenogenesis trilogy, these novels feature a post-apocalyptic earth where only a modified human can survive. As posthumans, Lilith'schildren are finally able to move beyond humanist gender, race, and class hierarchies.

Cyborg iconography in critical dystopias is very much a reaction to both the medical and cultural theories of cyborg life that emerged in the 1980s. In addition to 1980s developments in reproductive sciences, critical-dystopian cyborg images bourgeoned alongside two influential social theories within academic circles — posthumanism and biopolitics. Significantly, prominent scholars from both fields, Donna Haraway and Michel Foucault, mobilize cyborg metaphors in their criticisms of reigning power systems, and their speculations of cyborg futures intersect in productive ways. In this dissertation, I argue that authors of critical dystopias draw from, and ultimately hybridize, two kinds of cyborgs to map the perils and potential of high-tech reproduction and life. Most cyborgs in critical dystopias predominantly align with what Michel Foucault terms the "natural body," or what Donna Haraway calls the "man in space." In essence, powerful states and corporations implement posthuman programs designed to discipline the cyborg-subject and regulate the body politic. By introducing their cyborg figures as disciplined subjects of biopolitical states, authors of critical dystopias first deploy cyborg imagery as a means of critiquing contemporary trends. In other words, authors first situate the cyborg's origin 
story within the frameworks of reigning power systems in order to forecast the perils of staying the course.

However, the novels' ambiguous endings, a hallmark of the critical-dystopian genre, open potentials for the disciplined cyborg to wield her cyborganization to change her fate. The final images of critical-dystopian cyborgs encourage readers to imagine avenues for these characters, who have been designed and created by biopoitical programs, to reclaim and rewrite their origin stories and move towards what Haraway envisions as an ironical liberation. I call critical-dystopian hybrids of "natural body" and ironically liberated cyborg figures "biopolitical cyborgs." Like the critical-dystopian genre it inhabits, the biopolitical cyborg is a dystopian figure that is shot through with eutopian potential. These figures may predominantly work to reveal the ways modern systems of power discipline and shape their subjects, but the biopolitical cyborg's story is ultimately one of ironic hope. The eutopian potential of these figures is not prescriptive. These novels do not attempt to chart a definitive course from the dystopian present to a eutopian future. Instead, they conclude with images of cyborgs who have slowly come to understand their hybrid origins. The biopolitical cyborg's eutopian potential resides in her new understanding of herself as always already hybrid, not in a reactionary suggestion that she must overcome her cyborganization or return to a pre-cyborganized organic wholeness. Instead, these novels end with the suggestion that the cyborg is best equipped to challenge the status quo and envision a way out of the current darkness.

In her book Our Vampires, Ourselves, Nina Aurbach asserts, "the rapidity with which our Draculas become dated tells us only that every age embraces the vampire it needs" (145). The same could be said of the cyborg. The biopolitical cyborg is a product of its era. My theoretical introduction will begin by telling three interwoven histories that, together, capture the 
biopolitical cyborg's origin story: the evolution of literary utopias and the emergence of the critical-dystopian subgenre; Cold War fears of "nuclear bomb" and "population bomb" annihilation; and the US-Britain in vitro fertilization (IVF) race. Each history is imbued with widespread apocalyptic fears. From this potent convergence of fear, a new cyborg image is born. Following these historical surveys, I will draw from Foucault and Haraway to develop a theoretical framework for reading biopolitical cyborgs simultaneously as dystopian critiques of contemporary trends and as eutopian figures of resistance.

To articulate the complexity of cultural critiques these figures attempt, chapter 2 provides a taxonomy of biopolitical cyborg types. The first three figures are principally delineations of the biopolitical "natural body" image, and I primarily draw from Foucault's theories of biopower to pinpoint the critical focus of each figure. Though these figures generally adhere to Foucault's concept of the "body-machine complex," or "natural body," or what Haraway terms the "man in space," the novels gesture toward eutopian possibilities of an off-page "ironic" liberation for their cyborg protagonists (Foucault "Docile" 153, 155; Haraway "A Cyborg" 151). The fourth and final biopolitical figure I identify more fully embodies the "ironic" liberation of Haraway's second cyborg figure while also demonstrating the possibility for biopolitical cyborgs to learn to deny their "inessential" fathers and, in the process, open the "man in space's" apocalyptic fate to the possibility of a "world without end" (“A Cyborg” 151, 151, 150).

\section{Born of Fear: A Cyborgian Origin Story}

To better understand the emergence of the biopolitical cyborg in the 1980s, it is helpful to step back a bit further and examine three discrete post-WWII/Cold War trends, as well as the fears they invoke, that shape these critical-dystopian hybrid figures. The first occurs as a shift in themes and tones of American popular culture texts in the long 1950s. Keith M. Booker defines 
America's post-war/Cold War period by what he describes as an atmosphere of fear-induced "post-utopianism." He argues that after WWII, Americans, in general, lost the ability to imagine productive changes to the status quo. The critical-dystopian genre is a child of the post-utopian period and has been profoundly shaped by it, most notably by the genre's resistance to prescriptive eutopianism. A second context that shaped, and continues to shape, biopolitical cyborgs is the long-standing and pervasive fear of human-caused apocalypse that followed the US's bombing of Hiroshima and Nagasaki and continued throughout the Cold War period. I will look at this fear from two versions of Cold War apocalyptic iconography, the nuclear bomb and the population bomb. These icons influenced popular culture and government policy alike and dovetailed with women's movements for reproductive justice in powerful ways. Finally, the USBritain IVF race, which spans the Cold War period, was initially met with widespread fears that children created outside of the human body would somehow be less than human. After the first babies born from IVF proved to be healthy, normal humans, an IVF boom raised new fears of long-term socioeconomic consequences of the skyrocketing assisted reproductive technologies (ART) market. The biopolitical cyborg figures that emerge from the convergence of these contexts literally embody the fears of this period. Their worlds invoke the inevitability of a human-caused apocalypse, and their high-tech origin stories point to the potentials for states to wield ARTs and genetic technologies as weapons of biopolitical war, as well as the possibilities for privatized high-tech reproduction to capitalize on, and solidify, caste stratifications.

\section{Critical Dystopias}

Utopian definitions, categories, and ideas changed over the course of the twentieth century, so not all writers use terms such as "utopia" and "dystopia" in the same way. Further, 
the boundaries between various utopian categories are permeable and blurry, often making discerning between dystopia and eutopia difficult. For clarity, I have chosen to use Lyman Tower Sargent's 1994 definitions, taken from his article "Three Faces of Utopianism Revisited," as I find these to be the most clear and distinct. His definitions are also the ones most often cited by scholars of critical dystopias. According to Sargent, utopianism is simply "social dreaming" (1). He defines a utopia as "a non-existent society described in considerable detail and normally located in time and space" (9). As "utopia" has a cultural connotation of being a "perfect place," Sargent uses the term "eutopia" to refer to "a non-existent society described in considerable detail and normally located in time and space that the author intended a contemporaneous reader to view as considerably better than the society in which the reader lived" (my emphasis 9). Dystopia's definition is virtually the same, only changing "better than" to "worse than." In other words, both representations of "better" places and "worse" places are considered utopian imaginings and fit into the utopianism category (9).

A third definition is also important to this discussion, the anti-utopia. The anti-utopia depicts a society that "the author intended a contemporaneous reader to view as a criticism of utopianism or of some particular eutopia" (9). This means that the anti-utopia is not included within the framework of utopianism, as the anti-utopia resists all types of social dreaming. My references to utopianism will thus include both eutopian and dystopian texts, and only "eutopia" will be used to indicate a "better place."

In some ways, my story of utopianism in America begins with its death. Booker's The Post-Utopian Imagination insists that "utopianism did, in fact, collapse in the long 1950s (19461964)" and this “"post-utopian'... attitude became hegemonic during this period and has remained so" $(1,4)$. It is important to note that Booker does not limit his discussion to 
speculative fiction genres. He cites a variety of pop culture texts, including romance films and popular television series, to point to a general move away from social dreaming. Booker names this cultural phenomenon "post-utopianism," which he grounds in Fredric Jameson's definition of postmodernism. Jameson claims that postmodernism is "the cultural dominant" and "the cultural logic of late capitalism," and delineates the processes through which postmodernism decenters subjects, dissolves boundaries and binaries, and separates signifiers from their signifieds (Postmodernism). The overall effect of postmodernism, Jameson claims, is a social and cultural schizophrenia caused by a flattening or "disappearance of a sense of history." Booker re-names Jameson's postmodernism for two purposes: to narrow the phenomenon to the United States rather than attempting to analyze the more global, Western, movement, and because "[post-utopianism] calls attention to a much more specific aspect of the phenomenon than does the broader designation of postmodernism" (5). This more specific aspect is the "inability to imagine a preferable systemic alternative to the status quo, while at the same time imagining a historical process that might lead in the direction of that alternative" (5). In short, Americans in the 1950s lost the ability to imagine a better world, but lived in fear of creating a worse one. ${ }^{1}$ Again pulling from Jameson, Booker claims that utopianism is a "profoundly historical category" and "inherently totalizing," and is therefore inaccessible to postmodernism's schizophrenic subjects and their flattened histories (5).

Booker presents a trifecta of events, each culminated in the $1950 \mathrm{~s}$, as the reason utopian vision ended in America. The first is the post-WWII dominance of consumer capitalism.

\footnotetext{
${ }^{1}$ Booker's work primarily focuses on white middle-class Americans and mainstream American cultural texts. While dominant culture lived in fear of upsetting the status quo, civil and women's rights movements were mounting revolutionary campaigns to do just that. African-American literature, feminist writings, and the emergence of Beat poetry evidences the demand for eutopian dreaming and social change that dominant culture feared.
} 
Consumer capitalism enforces anti-utopianism, but wraps this logic in a faux-eutopian narrative. Capitalism offers "a limited utopian vision in its association of consumption with happiness," but this vision is "ultimately anti-utopian, because the desire upon which consumer capitalism is built is, of necessity, a desire that can never be satisfied. Meanwhile, the pursuit of this desire does not lead to the transformation of society but merely reinforces the status quo" (8). In other words, capitalism tells a story about itself that it is eutopia. If you are unhappy in your eutopiancapitalist society, the answer is to consume more. This logic quickly falls apart under scrutiny, so American capitalism must also discourage its subjects from imagining a different system. To do this, capitalist consumer culture crafts nostalgic visions of the past, "helping to ensure that any critique of the present would offer the past as the only alternative, thus foreclosing radical movement toward the future" (8). This idea of capitalism resisting and denying utopian dreaming is, I think, best captured by Darko Suvins:

Capitalism co-opts all it can from utopia (not the name it abhors) and invents its own, new, dynamic locus. It pretends this is a finally realized eutopia (end of qualitative history); but since it is in fact for 85 percent of humanity clearly and for 13-14 percent subterraneously a dystopia, it demands to be called Anti-Utopia. We live in an ever faster circulation of a whirligig of fads that do not better human relationships but allow heightened oppression and exploitation, especially of women, children, and the poor, in "a remarkably dynamic society that goes nowhere." ("Theses on Dystopia")

Capitalism insists that utopian dreaming is no longer necessary as eutopia is here. Thus, any attempt to imagine a different system or a different future would inevitably be a turn away from eutopia and towards dystopia. 
Though the dominance of capitalism would seem to be enough to stave off utopian dreaming, Booker presents it as only one of three concurrent trends. The second is his claim that, despite its eutopian gloss, American society in the 1950s was dominated by fear. America exited WWII as the new global power, and that position was terrifying. He claims that the immediate entrance into the Cold War created a "siege mentality" in which Americans perceived themselves to be always in danger from attacks by nuclear bombs, Soviet communism, and the "savage hoards of the Third World" (2). Not all threats to America and the American way of life were external. White, middle class Americans feared changes to their privileged status as the result of movements challenging racial, gender, and socioeconomic oppression. They feared losing their individuality to consumer capitalism, which limited its definitions of the good life and the proper citizen to products and production of those products. Conversely, they feared "being different" in a system that enforced rigid adherence to social and cultural norms. And finally, they feared their youth, who seemed to be growing more angsty and angry. Though such fears may lead to an increase in utopian dreaming in other circumstances, consumer capitalist culture assured the feared masses that trust in the current system was the only way to assuage these concerns.

While middle- and upper-class white America lived in fear of any movement away from the white, patriarchal-capitalist status quo, Americans of color were living in the midst of a centuries-long dystopia. Nigerian-American author Nnedi Okorafor recently reminded Americans who are now (re)turning to 1984 and The Handmaid's Tale for guidance following Trump's 2017 inauguration that, "the definition of dystopia depends on the group of people" 
you're talking to ("The Rise). ${ }^{2}$ The authoritarian societies featured in classic dystopias share many qualities with American slavery and life in the Jim Crow South. Citing an interview with a professor of African-American literature, Washington Post editor Ron Charles recounts, "she said what's so interesting to her is that white people always think of dystopias as looking forward into this scary future, but black Americans can look back...All the kinds of things we imagine the future dystopia being like are what black Americans already went through" ("The Rise"). Ironically, the anti-utopian trend Booker describes is concurrent with racial segregation, voter suppression, lynchings, redlining, state-run eugenics programs, and legal all-white jury selections. In short, at the heart of white America's anti-utopian sentiments was the fear of being subjected to the types of systems already oppressing America's communities of color.

Booker's third cause for the rise of post-utopianism is the "ironic culmination" of what he calls the narrative of the Americas as a eutopian land of promise and prosperity. He traces the long history of European texts and narratives that describe or envision the Americas as the site where eutopia is possible. This eutopian possibility, he argues, worked to justify the removal and genocide of all "others" who stood in the way of eutopian creation. He calls the 1950s an "ironic culmination" because America made its entrance as a world power by its nuclear annihilation of Hiroshima and Nagasaki, while at the same time proclaiming that consumer capitalism's dominance has resulted in eutopia's arrival in America. Booker believes that Americans "had a difficult time rectifying its utopian rhetoric of defenders of freedom and peace, when the bombings laid bare a national narrative of violent victory over anyone who was different" (9). Booker acknowledges that America is far from alone in its history of coming to power by the systematic oppression, genocide, and removal of "others"; however, America is distinct in its

\footnotetext{
${ }^{2}$ Okorafor is rereading Octavia Butler's Parable of the Sower: "I feel like if we're looking for any answers or where we're going, it's definitely in Octavia's work."
} 
impossibility of rectifying this history with its equally long historical narrative as the land of peace, prosperity, and promise. Taken together, consumer capitalism's anti-utopian insistence, the atmosphere of pervasive and multifaceted fears, and the historical narrative of America as the land of eutopian possibilty, resulted in the near-complete death of utopian dreaming in the United States. ${ }^{3}$

Jameson's Archaeologies of the Future adds to Booker's list of post-utopian causes: the twentieth-century conflation of utopianism with failed socialist and communist programs, and consequently, utopianism's association with liberal political theory. Twentieth-century totalitarian regimes, which implemented bastardized versions of Marxist utopianism, have permanently discredited utopianism's potential as a meaningful political activity. According to Jameson, to revive utopianism, we must banish it from liberal political theory. To do this, we must shift utopianism from "content" to "form," from noun to adjective, and/or from "utopian imagination" to "utopian fancy." Utopianism must be imagined as small details and actions that flicker with eutopian possibility rather than designed, mapped, and executed eutopian programs. The moment we try to plan, program, and define eutopia, that form of utopianism becomes ideology. Resonating with Ernst Bloch's insistence that eutopia is not attainable as it is always located outside reality, Jameson asserts that only by removing utopianism from its associations with liberal theory, which he describes as "the composition of blueprints for bourgeois comfort," can possible transformations to the systemic totality of late capitalism be imagined

\section{(Archaeologies 12).}

Jameson insists that utopianism is a "negative critical principle," meaning utopianism is best used as a tool for pointing out flaws in current systems, but is "not some conceptual nugget

\footnotetext{
${ }^{3}$ For a study of the ways post-war culture both influenced and was challenged by SF written by women, see Lisa Yaszek's Galactic Suburbia: Recovering Women's Science Fiction. Columbus, OH: The Ohio State University Press, 2008.
} 
we can extract and store away, with a view towards using it as the building block of some future system" (Archaeologies 175). In sum, utopianism's bad reputation is somewhat earned, as it is the result of failed attempts to define, map, and implement eutopia, which, according to Jameson (and Bloch, and Suvin), can't be done. Utopia is, and will always be, located outside of the here and now. Its power and possibility reside in being an imagined place. Though utopianism is a powerful tool for critiquing real-life systems, it cannot be captured, contained, and implemented without becoming another oppressive system.

Still, Jameson insists on the necessity of continuing to dream utopian dreams. In a postutopian environment that discourages, and in some ways makes impossible, eutopiansim, he offers a surprising locale for eutopian imaginings: "Indeed, when we reach late or postmodern capitalism - that stage of finance capital in which Utopian impulses and alternatives have been stifled and suppressed as much as possible — some of those energies seep into what used to be dystopian figures" (my emphasis Archaeologies 161). At this point in our narrative, eutopian dreaming in America has fallen victim to postmodernism, consumer capitalism, and failed "utopian" programs; however, it finds new life in a new speculative fiction genre: the critical dystopia.

Raffaella Baccolini and Tom Moylan's edited collection, Dark Horizons, presents a body of work that developed out of the 1999 Millennium of Utopias conference. Taken together, the essays argue for and define a new category of utopian literature, the critical dystopia. Baccolini and Moylan begin by presenting a historical trajectory of utopian literature beginning in the $19^{\text {th }}$ century. They claim that the prominence of eutopian literature, both in Europe and the US, began to give way to dystopian literature at the turn of the century. The early and mid-twentieth century saw the emergence and development of the closed dystopia, which dominated utopianism until 
the 1960s. Eutopianism saw a brief revival in the 1960s and 1970s in the "critical eutopia," a less formulaic and more open eutopianism which was largely the product of feminist social movements of the day. However, the new genre of hope stalled with the rise of neoliberal conservatism that culminated in the elections of Ronald Reagan and Margaret Thatcher. According to Baccolini and Moylan, "in the face of socioeconomic restructuring, right-wing politics, and a cultural milieu informed by an intensifying fundamentalism and commodification, sf writers revived and reformulated the dystopian genre" to critique the New Right and the rise of conservatism (2). The result was the emergence of the critical dystopia, the nemesis of the antiutopia, which contains elements of both eutopianism and dystopiansim.

The critical dystopia stays true to some earlier dystopian conventions. These novels tend to open in medias res and "the text is built around the construction of a narrative of the hegemonic order and a counter-narrative of resistance...the protagonist [and the reader] is always already in the world in question, unreflectively immersed in the society. However, a counter-narrative develops as the dystopian citizen moves from apparent contentment into an experience of alienation and resistance" (5). Basically, the reader is placed directly in the middle of a nightmarish hellscape and follows the journey of the protagonist as she discovers the horror of her world and mounts a feeble resistance to its power structures. Though critical dystopias maintain this narrative frame, they differ from earlier, closed dystopias in significant ways, which clearly differentiate them from anti-utopias. Closed dystopias offer little hope to the protagonist or reader (i.e., 1984). These closed endings can easily lead to anti-utopian readings, or warnings that changes to the current system will lead to social nightmares with no hope of transformation or escape. Most of the essays in Baccolini and Moylan's collection focus on two defining features of critical dystopias that resist anti-utopian interpretations and ultimately result 
in the critical dystopia as being a genre of hope and possibility: open or ambiguous endings and blended genres. To borrow Baccolini and Moylan's phrasing, critical dystopian endings distance themselves from anti-utopias by "maintaining a utopian impulse" by including "at least one eutopian enclave" or "[holding] out hope that the dystopia can be overcome and replaced with a eutopia" (7). This does not mean that critical dystopias include happy endings. Often, the endings are ambiguous. This places eutopian hope outside of the page and encourages the reader to participate in utopian dreaming in order to imagine how the protagonist's story might end.

The second dominant feature of the critical dystopia is its tendency to blend literary genres. Baccolini and Moylan equate this genre blending, which is also a common feature of feminist SF, with hegemonic resistance. If Jameson is correct, and genres are "literary institutions, or social contracts between a writer and a specific public" (qtd by Baccolini, "Gender and Genre"), and these literary institutions have been established within oppressive patriarchal and classist systems, then defying generic conventions by blending them (in effect, bastardizing them) is an act of resistance and utopian reimagining of a different system:

Drawing on the feminist criticism of universalist assumptions - fixity and singularity, and neutral and objective knowledge — and recognizing the importance of difference, multiplicity, and complexity, of partial and situated knowledges, as well as of hybridity and fluidity, the critical dystopias resist genre purity in favor of an impure or hybrid text that renovates dystopian sf by making it formally and politically oppositional... thus, it is the very notion of an impure genre, with permeable borders which allow contamination from other genres, that represents resistance to hegemonic ideology that reduces everything to a global monoculture. (7-8) 
As Booker notes, Jameson's early theories of postmodernism are often criticized as being too pessimistic and somewhat nostalgic for modernist art and humanist absolutes. This criticism is grounded in Jameson's portrayals of the hopeless schizophrenic who can't orient himself in history or reality in order to imagine a different future. Critical dystopias, in a way, respond to this postmodern pessimism by taking advantage of permeable and dissolved boundaries in order to craft new images of the future. In other words, while critical dystopias are dark and are set in "worse" places, they are able to capture eutopian flashes in dystopian settings.

Critical dystopia's blended genres and ambiguous endings allow flickers of eutopian hope and possibility to seep from otherwise nightmarish and hopeless settings. They refuse to provide definitive answers or blueprints for attaining a eutopian future; instead, they encourage the reader to actively participate in utopian dreaming by imagining a future beyond and outside of the page, and their blended structures provide a small example of resisting oppressive institutions through hybridity. In this way, the genre's hallmark features mirror the cultural work of the cyborg protagonists they often include.

\section{Nuclear Bombs and Nuclear Families}

Just as the critical-dystopian genre responds to contemporary trends by reconfiguring elements of earlier utopian genres, so too does the biopolitical cyborg adapt older cyborg figures to address new cultural contexts. To better understand the origins of critical-dystopian cyborgs, it is helpful to survey the history in which, to borrow N. Katherine Hayles's phrasing, "the cyborg was created as a technological artifact and cultural icon in the years following World War II" (emphasis in original 2). Scientists Manfred E. Clynes and Nathan S. Kline coined the term cyborg in their 1960 Astronautics article, "Cyborgs and Space." The article captures the midcentury preoccupation with the "cybernetic paradigm" that developed out of the Macy 
Conferences on Cybernetics (1943-54) in which, "henceforth, humans were to be seen primarily as information-processing entities who are essentially similar to intelligent machines" (emphasis in original, Hayles 7). Cybernetics introduced the conceptualization of information as a disembodied entity that travels through a human or machine "body" but isn't necessarily part of it, casting humans and machines as "brothers under the skin" (Hayles 50). This opens the door to envisioning cybernetic systems capable of passing information across and between human and machine bodies by constructing homeostatic information, or feedback, loops. Clynes and Kline's article builds from these ideas to argue that American astronautics should reverse its aim from endeavoring to create earthlike environments for men traveling in space (i.e., spaceships and spacesuits) to imagining ways to integrate cybernetic technologies into the human body, "altering man's bodily functions to meet the requirements of extraterrestrial environments." More simply, Clynes and Kline suggest that NASA should design human bodies to withstand space rather than attempting to make space inhabitable for humans.

Cylnes and Kline's enthusiasm for cyborganization comes from their optimistic belief that a merger of the human body with cybernetics would emancipate man from his "slave[ry]to the machine" by making him one with it. If body and cybernetic system could operate together, "automatically and unconsciously," then "man" would be left "free to explore, to create, to think, and to feel" in space (27). Clynes and Kline's cyborg portmanteau melds cybernetic and organic systems — or human and machine — seamlessly, so that the two systems are codependent and no longer distinguishable from each other. This hybridization is intended to "free" the astronaut's mind. Whereas a human space traveler's thoughts are necessarily preoccupied with maintaining the spaceship or spacesuit that is sustaining his life, the cyborg astronaut's mind is liberated from 
the burden of "continuously...checking on things and making adjustments merely in order to keep himself alive."

The two scientists clearly envisioned their space-traveling cyborgs as eutopian symbols of individual liberation; however, their bionic vision cannot be extricated from the Cold War contexts driving the era's astronautics ambitions. The era's cybernetic enthusiasm was born of militaristic contexts, as 'Norbert Weiner invented the term 'cybernetic' to describe the types of self-correcting weapons systems he had been developing and analyzing during and after World War II" (Bendle 56). Writing after Russia took the Space Race lead with the launches of Sputnik in 1955 and Luna 2 in 1959, Clynes and Kline's cyborg is imbued with America's Cold War compulsion to be the first nation to send a man into space, a contest Russia would win the following year. Though the authors keep the tone of the article light and avoid direct references to the Space Race, America's anxiety of Russia’s technological superiority seeps from between the lines of their concluding paragraph: "Although some of the proposed solutions may appear fanciful, it should be noted that there are references in the Soviet technical literature to the research in many of these same areas" (76). The emotional subtext of the scientists' hope-filled social dream is fear-fear that Russia's dominance of the space frontier signals their imminent colonization of American culture and values. Clynes and Kline's cyborgs are not individual minds finally freed of their bodily limitations and left to explore the far reaches of the galaxy; they are enhanced super-soldiers, born of ideological war, whose ability to withstand extraterrestrial environments symbolizes the global dominance of American Christian capitalism over Russian secular communism.

Clynes and Kline acknowledge the moments when their cyborg astronaut blurs lines separating scientific inquiry and speculative fiction. In their own words, their blueprint for 
cyborganization draws from "presently available knowledge and techniques" while adding futuristic technologies that, "by their very nature must resemble science fiction" (27). It comes as little surprise, then, that while "Cyborgs and Space" made few waves in the field of astronautics, Clynes and Kline's cyborg image gave a name to popular figures in American popular culture throughout the Cold War period. In the decades surrounding Clynes and Kline's article, mainstream science fictional television and film honed in on and popularized the capitalistic and militaristic undertones of Clynes and Kline's "man in space." Perhaps the most obvious examples of this figure type are Darth Vader and his planet-destroying Death Star and Steve Austin of the Cyborg/Six Million Dollar Man franchise.

In 1972, Martin Caidin used Clynes and Kline's term to title his SF novel, Cyborg. The novel also pays tribute to the work of US Air Force colonel and medical doctor Jack E. Steele who coined the term "bionics" in 1958. Cyborg tells the story of pilot and astronaut Steve Austin who loses most of his limbs, along with his vision in one eye, in a crash landing. Austin's air and space expertise are of interest to the Office of Strategic Operations (OSO), a secret government agency charged with developing bionics technologies. The OSO seizes the opportunity to test their advancements by rebuilding Austin's limbs with mechanical prosthetics and replacing his damaged eye with a miniature, removable camera. Austin's bionic limbs enhance his human strength and agility and, significantly, are also weaponized. Once Austin's cyborganization is complete, he is conscripted into the OSO and sent to the Middle East as a secret agent. Though he initially resists and resents his new role as bionic super-soldier, he gradually accepts both his new mechanized body and his military assignments. Caidin's novel was adapted to the screen in the 1973 made-for-TV movie The Six Million Dollar Man, which was quickly followed by the sequels Wine, Women, and War and Solid Gold Kidnapping. The popularity of the franchise led 
to the 1974 television series, The Six Million Dollar Man starring Lee Majors as Steve Austin. The TV series loosely follows Caidin's novel while amplifying the abilities of Austin's bionic limbs. A television spin-off, The Bionic Woman, starring Lindsay Wagner, followed in 1976, in which secret agent and bionic woman Jaime Sommers poses as a middle school teacher when she is not using her superhuman strength and enhanced senses in top-secret military missions. The Cyborg/Six Million Dollar Man story arch was also adapted as a comic line beginning in $1976 .{ }^{4}$ Pop-culture science fictional cyborgs of the 1960s and 1970s brought the Cold War subtexts of Clynes and Kline's vision to life. Whereas "Cyborgs and Space" leaves the connections between cyborganization and the industrial military complex implicit, the fictive bionic men and women popularized on screen are literal soldiers whose cyborganization was forced upon them by military agencies. Though these cyborgs are given enhanced, superhuman physical abilities, these abilities double as weapons of war and render the cyborg's body—both machine and human parts - as property of the military. Thus, the cyborgs in these texts have less personal agency and political autonomy than their non-enhanced human peers.

These pop-culture weaponized cyborgs resonate with Foucault's descriptions of the intersections of disciplinary power and biopolitics introduced in "Docile Bodies." Also employing a hybrid metaphor, Foucault argues that the combination of man + machine was designed as a mechanism to discipline individuals to think and act in accordance with power systems' agendas. According to Foucault, disciplinary power first emerged as a semi-cyborgian merger of soldier + gun. Military sciences began to think of the soldier as an individual who would be most effective if he was trained to think and act seemingly autonomously. This began

\footnotetext{
${ }^{4}$ Marvel's Deathlok comic line, featuring Colonel Luther Manning, also shares many themes with Caidin's cyborg legacy, including the military use of cyborg technologies to create supersoldiers. Stan Lee, for example, created the comic character Iron Man in 1963 narrate what he saw as the militarization of American business and technology in the war against communism.
} 
with an emphasis on marksmanship by developing training methods for the soldier to think of himself as one with his gun, thus the merger of man + machine into a "body-machine complex" ("Docile Bodies" 153). The disciplined soldier begins to think of his hybridized union with his gun as his "natural body," thus masking his compulsion to comply behind a façade of free will. Foucault claims that these military strategies were gradually adjusted and applied to non-military facets of society, such as education, medicine, prison, and law, in order to create selfdisciplining, man/machine citizens. The cyborg of Foucault's imagination is a self-policing subject of disciplinary power.

Haraway also describes this cyborg character, which she terms the "man in space" and more concretely connects it to Cold War fears in her 1985 "A Cyborg Manifesto." The "man in space" is an apocalyptic figure, and as such, resonates with Cold War nuclear bomb iconography. The "man in space's" fate is sealed by its origin story as the child of patriarchal capitalism and modern warfare. According to this narrative trajectory, which is wrapped up in Western myths of original (edenic/pre-Oedipal) organic wholeness and innocence, the "man in space" cyborg functions metaphorically as the "awful apocalyptic telos" of Man's fall from original wholeness in the garden (150). Fall mythology and its "imagination of a once-upon-atime wholeness before language, before writing, before Man," embeds dualisms into the very fabric of Western ideologies and power structures (175). The Fall signals a fracturing of the "whole" self into the dualism of self/other in a system that defines the self as "the One who is not dominated" (177).

According to Haraway, "To be One is to be autonomous, to be powerful, to be God; but to be One is an illusion, and so to be involved in a dialectic of apocalypse with the other" (177). The other is the enemy, but the other is also the self. Haraway emphasizes the power of this myth 
in her claim that "we have all been colonized by those origin myths, with their longing for fulfillment in apocalypse" (175). In the age of the cyborg, this final apocalypse could arise from cyborg-fought Star Wars that return Man to his original wholeness as a pile of nuclear dust. Such apocalyptic visions constrain the cyborg's origin story to its status as a product of humanist power structures. When viewed from this vantage point, "a cyborg world is about the final imposition of a grid of control on the planet, about the final abstraction embodied in a Star Wars apocalypse waged in the name of defense, about the final appropriation of women's bodies in a masculinist orgy of war" (154).

In "natural body" or "man in space" iconography, cyborganization is depicted as a tool wielded by patriarchal capitalist states to both tighten their grip on their body politics and wage civil and interstate wars against others. Images of the disciplined bionic super-soldier, which dominated visual pop-culture representations of the cyborg throughout the Cold War period, embodied the fears and fates of apocalypse that Foucault and Haraway describe. The fictional adventures of these super-soldiers play out against the very real backdrop of Cold War fears of an imminent nuclear apocalypse. Biopolitical cyborgs harness the disciplinary and militaristic themes embodied in Darth Vader and Steve Austin, but, by shifting focus from weaponized bionic prosthetics to ARTs and genetic engineering, they also invoke a second Cold War apocalyptic icon-the population bomb.

According to US Cold War logic, "poverty bred communism, and birth control was the solution" (Murphy 15). While the era's visual cyborg texts often feature ideological world wars and evoke widespread anxieties of the nuclear bomb as the harbinger of doom, threats of a different kind of bomb - the "population bomb" - quietly influenced much Cold War foreign policy and military action. Michelle Murphy argues that the icon of the nuclear bomb "could 
well be joined by the pill as another icon of the Cold War, used to thwart purported explosive planetary problems of famine, war, and unfreedom caused by the so-called population bomb" (16). In 1959, President Eisenhower commissioned the Draper Committee, led by General William Draper, to develop a comprehensive program for staving off communist encroachment in both "least developed" and recently decolonized countries. The committee's conclusions, published in the Draper report, recommended pursuing three offensive fronts: continuing military aid; offering strategic economic aid via the formulation of the U.S. Agency of International Development (USAID); and finally, distributing birth control, as "only with population control could the United States get 'the maximum result out of our expenditure' and achieve military security" (Murphy15). Murphy's deft analysis of the report's militarization of reproduction is worth quoting at length:

With the pill given away as a form of foreign aid, the term nuclear family took a militarized turn. The population bomb became another figuration of human mass destruction, seeming to necessitate that the United States both fund familyplanning programs along the front lines of the Cold War, and become involved in social science decolonization projects that invented new ways of calculating livesnot-to-be-born as "targets" of population control. In this way, family planning had a particular necropolitical effect—fostering methods for determining lives less worth living in the name of avoiding future death and creating future prosperity...Reproduction was militarized in that family planning could be mobilized to promise a deterrence of future war through its focus on the temporal frame of the "not yet conceived." (16) 
The Draper report was met with immediate opposition from America's Catholic Bishops and was eventually rejected by Congress. Initially, Eisenhower sided with those who opposed to the federal distribution of birth control, declaring "I cannot imagine anything more emphatically a subject that is not a proper political or governmental activity or function or responsibility" (quoted in Eig 284). However, Eisenhower's position would later shift to an advocacy of federally funded family planning initiatives, including contraceptive distribution.

Cold War fears of the population bomb dovetailed with women's movements demanding legal access to contraceptives within the United States. Margaret Sanger, specifically, took advantage of the Draper report's suggestions to publically advance women's efforts for birth control within the US. In 1960, she penned a letter to The New York Times criticizing Eisenhower for bending to the will of the Catholic Church in regards to the Draper report (Eig 295). Conflicting public pressures regarding the government's role in family planning continued to mount through John F. Kennedy's presidency and into Lyndon Johnson's, who supported family planning efforts in countries, such as India, to which the US was already providing aid in the form of food supplies. The Johnson administration took advantage of mounting popular approval of contraceptive use to put in place a plan to finally realize the visions outlined in the Draper report:

By 1967, \$35 million of the budget of the USAID was earmarked for family planning; during its peak between 1968 and 1972, U.S. government aid accounted for 80 percent of all international assistance for population programs. American foreign aid put such great emphasis on family planning during the late 1960s and 1970s that it shortchanged other types of aid. The head of the USAID population program, Reimert Ravenholt, "inundated" countries in the global South with free 
contraceptives, including IUDs, and abortion kits believing that flooding the region with birth control methods would lead to more acceptance and use. By 1979, the United States had paid for over 70 percent of the world's research in reproduction and contraception. (Takeshita 11-12)

In essence, the federal government was busy flooding the developing world with free contraceptives and abortion kits at the same time middle- and upper-class American women were fighting for legal and affordable access to these same products and procedures. Further, while the Draper report is distinctive for explicitly envisioning population control as a military strategy, the resulting global distribution of contraceptives was far from the first government effort to control birthrates of various social castes. Rather, the committee's turn to global population control adapted rhetorical justifications for the US's long-standing eugenics programs that primarily targeted poor women of color. ${ }^{5}$

The 1920s witnessed a groundswell of support for eugenics programs among many progressive groups. The popular support for eugenics programs stemmed from the fear that too many of the "wrong" kinds of women were reproducing at too fast a rate, and controlling birth rates of minority and poor populations might provide the best avenue to "ensure the health of the 'native' white European Protestant population" (Flavin 16). The eugenics movement operated on two fronts: positive eugenics and negative eugenics. Positive eugenics tactics targeted middleand upper-class Christian white women by encouraging them to regard child bearing as a civic duty and moral obligation, as best captured in President Theodore Roosevelt's terming of such women who chose not to have children as "race criminals" (quoted in Flavin 16). Positive eugenics campaigns propagated fears of "race suicide" by "advancing the notion that not only

\footnotetext{
${ }^{5}$ See: Ragoné, Heléna and Rance Winddance Twine, Eds. Ideologies and Technologies of Motherhood: Race, Class, Sexuality, Nationalism. NY: Routledge, 2000. Print.
} 
were immigrant women intellectually and morally inferior but they also could pass on deviant traits to their many offspring" (Flavin 16).

The denigration of the "wrong" kind of mother in positive eugenics campaigns worked to justify negative eugenics programs that targeted poor communities and women of color by institutionalizing them, sterilizing them, or often both (Flavin 16). The labels "feeble-minded" and "sexually delinquent," which legally justified involuntary institutionalization and sterilization, became catchall terms encapsulating the range of "women's deficiencies" from poverty to pre-marital sex. Though popular support for eugenics programs declined significantly following WWII as the horrors of Nazi eugenics programs came to light, many states actively maintained "repackaged" negative eugenics programs, including forced and coerced sterilization of minorities, single mothers, and incarcerated persons, well into the second half of the twentieth century (Stern 3). In 1965, 28 states maintained eugenics boards that legally sanctioned involuntary sterilizations both within and outside of state-run institutions. Proponents of these later eugenics programs no longer cited beliefs in genetic causes of poverty or feeblemindedness; rather, justifications for maintaining eugenics boards mirrored the language used in the Draper report's advocacy of birth control by suggesting that "poverty was caused by poor women having too many children, rather than dropping wages or lack of social support. To this way of thinking —and one that persists today—reducing the number of children born to poor women would alleviate poverty" (Flavin 16). In other words, eugenics programs were pitched as a viable way to reduce government spending on welfare projects. Under this rubric, "tens of thousands" of sterilizations, mostly involuntary, were "disproportionally performed on Native American, black, and Hispanic women" between 1960 and 1970 (Flavin 16). ${ }^{6}$

\footnotetext{
${ }^{6}$ See Also: Christine Rosen's Preaching Eugenics: Religious Leaders and the American Eugenics Movement. NY: Oxford University Press, 2004; Edwin Black's War Against the Weak: Eugenics and America's Campaign to Create
} 
Cold War apocalyptic iconography of nuclear bombs and population bombs not only propagated two imminent threats to the American body politic, but also aided in the militarization of reproduction. Significantly, biotech, specifically the pill, IUDs, and abortion kits, played a large role in the conceptualization of birth control as critical offensive tactics in dual ideological wars waged against global overpopulation and the spread of communism. The US's history of eugenics programs, which predated Cold War fears, positions the Draper report as an evolution and amplification of America's long and checkered history of determining who should and who should not reproduce. Biopolitical cyborg figures often embody themes of militarized reproduction by envisioning worlds in which further developments in reproductive and genetic technologies are similarly wielded as weapons of biopolitical wars. Towards the end of the Cold War, the first successful IVF births in Britain and the US would add another dynamic — consumer capitalism — to the tensions surrounding reproductive biotech, and would also fundamentally influence visions of biopolitical cyborgs.

\section{IVF Race}

Just as the US-Russia Space Race inspired visions of bionic super-soldiers, the USBritain IVF race, which preoccupied public discourse in both countries beginning in the mid1960s, planted seeds for critical-dystopian depictions of genetically modified and lab-born cyborgs. Bionic cyborg figures imagine science applied to already-born and formed humans. Assistive reproductive technologies, on the other hand, blend human processes and machine processes in order to create life, rendering the natural and the artificial truly indistinguishable. American culture broadly found this shift in hybridity, from post-birth to pre-conception 
cyborganization, unsettling. According to a 1969 Harris poll, the majority of Americans found IVF, artificial insemination, and surrogacy to be "against God's will" (Henig 50). In addition to citing fears that children created and born via ARTs could be abnormal, the majority who opposed these emerging technologies feared long-term consequences of altered familial structures and norms. Specifically, the public feared that ATRs would "encourage promiscuity" and signify "the end of babies born through love" (Henig 50).

Moral and ethical debates regarding ATRs raged throughout the IVF race. A July 27, 1978 headline in New York Daily News for an article announcing the live birth of the world's first "test-tube baby" evidences lingering widespread apprehensions of advances in reproductive medicine: "Test Tube Birth: a Blessed Event? Amid Joy, Warnings." Despite the attending doctor's multiple assurances that the birth produced a "perfectly normal child," a "beautiful, normal baby," the article emphasizes that public "jubilation" of the birth is "tempered" by both explicit "warnings over the morality and ethics of producing human life in the laboratory," and implicit fears that what appears to be a normal baby will eventually expose abnormal characteristics (Edelson).

However, public opinion of IVFs and other ARTs underwent a drastic shift during the 1980s and 1990s. As more and more IVF births produced normal, healthy, very much human babies, fears that unconventionally conceived children would suffer deformities, illness, or even soullessness, gave way to a growing belief in biomedicine's potential to increase individual reproductive agency. IVF promised to open the door to parenthood to those struggling with infertility, to same-sex couples, and to older women. Further, IVF made Preimplantation Genetic Diagnosis (PGD) and Genetic Selection possible. While polarized fringe camps continued to dominate public discourses about ARTs and PGD through the 1980s, and the Vatican continued 
to vocally oppose IVF, mainstream acceptance of biomedical assistance in making human life surged during the early 1990s (Mundy; Henig).

The loudest opponents of biomedical tech during the IVF boom decried the morality of tampering with life processes; however, a quieter group of ART and PGD skeptics also began to emerge as more and more IVF clinics popped up. This group of reproductive tech dissenters criticized the ATR and PGD markets rather than the technologies themselves. In America, IVF and PGD procedures fall outside of the highly regulated medical field and are more susceptible to the free market. Early anti-IVF groups effectively blocked public funding for fertility technology development, relegating IVF's development in the US to private ventures. Despite its crippling cost (\$12,000-\$50,000 per IVF round) and excruciatingly low initial success rates, the hope IVF gave to infertile men and women drove an immediate industry boom following the first, highly publicized IVF births. IVF clinics, which required little space and equipment, popped up in malls and other "nondescript" locations nationwide: "In 1986, there were 41 IVF clinics in the United States, according to an early registry. By 1996, that number would rise to more than 300, an increase of more than 700 percent. Ten years later there would be more than 400 clinics" (Mundy 37-8). According to the CDC's "National ART Outcomes Report," 208,786 IVF cycles were performed in the US in 2014, resulting in 57,323 live births (including multiple births) of 70,354 infants (3).

A growing number of groups opposed the high cost of IVF, fearing it would make assistance available only to the wealthy. Corresponding developments in PGD amplified these fears, as PGD opened the door to genetic selection and genetic design, a.k.a. "designer babies." In essence, people feared that wealthy parents could use PGD to select only the "best" genes to 
create intelligent, athletic, and physically attractive children. ${ }^{7}$ Theoretically, some warned, designer babies could amplify unjust social and economic hierarchies, since parents would be willing to pay exorbitant amounts to ensure their children a spot on the top of the socioeconomic ladder (Mundy; Henig).

\section{Fruitful Couplings}

Biopolitical Cyborg images in critical-dystopian fiction marshal the disparate threads of anti-utopianism, human-caused apocalypse, militarized reproduction, and skyrocketing ART markets in one figure - a disciplined, hybridized citizen of a future dystopian society that failed to heed the warnings and lessons of the twentieth century. However, these figures ultimately refuse to fully accept the fates their "fathers" designed for them. In the critical dystopias I examine, biopolitical cyborgs are positioned as the protagonists. The narratives follow the cyborg's journey from an unwitting disciplined subject to a reluctant citizen wary of the ways cyborganization has been used to determine her life, thoughts, and abilities. Often set in postapocalyptic worlds, stories of biopolitical cyborgs resist post-utopian and anti-utopian nostalgia by refusing to offer their cyborg protagonists a way to go back to pre-cyborgian existence. Instead, these cyborgs must harness the eutopian potential of their hybridity in order to recuperate the ability to imagine a different world. The potentials for these characters to create

${ }^{7}$ PGD procedures have also come under scrutiny by many who fear that the scientific ability to eliminate certain genetic abnormalities and diseases could unintentionally work to reinforce damaging cultural norms. While some argue that the process of selecting and implanting only genetically "normal" embryos reflects the ways culture already devalues the lives of people affected by genetic diseases, others, most famously the IVF pioneer Robert Edwards, forecast potentials for PGD to lead to cultural attitudes, and potentially legislative measures, that work to hinder parental choices: "soon it will be a sin for parents to have a child which carries the heavy burden of a genetic disease." 
better futures beyond the page depend on the cyborg's ability to leverage her hybridity to challenge and disrupt anti-utopian hegemonic structures.

Junot Díaz defines apocalypse as a "darkness that gives us light." He argues that the work of the apocalypse is to "uncover and unveil," in that "in the process of causing things to fall apart they also give us a chance to see the aspects of our world that we as a society seek to run from, that we hide behind veils of denials." By "wash[ing] away the surface of society," apocalypses "allow us insight into the conditions that led to the catastrophe." Díaz encourages us, when faced with apocalyptic horror, to become "ruin-readers" who stare into the darkness, for "apocalypses are not only catastrophes; they are also opportunities: chances for us to see ourselves, to change."

The nightmarish hellscapes of critical dystopias offer a similar invitation to "peer into the darkness" in order to better understand the dystopian elements of our current world. Two theoretical lights help us peer into the darkness of critical dystopias and decode the messages we find in their ruins. To best articulate the dystopian and apocalyptic elements of biopolitical cyborgs, I turn to Foucault's formulation of biopower. Foucault may seem like an unlikely choice for a dissertation that examines the cultural implications of advanced reproductive technologies, technologies that unevenly affect women's bodies and experiences. As Murphy rightly notes, "Foucault's own formulation of biopolitics, which focused on middle-class Europeans, largely foreclosed considerations of colonialism, capitalism reproduction, or even women" (11). However, I agree with her assessment that "there is something profoundly useful about the way Foucault initially posed the question of biopolitics as the history of governing living-being," and "offered the insight that through a form of often racialized biopolitics, society came to be at war with itself, concerned with the enemy to life within as much as the enemy 
without" (13). ${ }^{8}$ It is through this lens that we can best glean the warnings of these novels as to how biotech designed to aid in the creation of life could be used by power systems to both determine what kinds of lives are created and to control the lives they "let live" (Foucault Society 274).

In his 1975-76 lecture series entitled Society Must Be Defended, which presents his first extended formulation of biopolitics, Foucault defines biopower as "the new discursive regulation of populations through surveillance and control of their health, sexuality, reproduction, and so on" (4). According to Foucault, the goal of biopolitical systems is to maintain homeostasis of the population and of wealth distribution, which requires the state to govern the birth rates of its various classes. Stressing that technologies of power operate simultaneously, Foucault positions disciplinary power and biopower (sometimes referred to as regulatory power) as two poles between which the "norm" of society circulates, normalizing the individual through discipline and the population through biopower. Whereas the mechanisms of discipline target the individual body and are primarily institutions designed to "manufacture subjects," the mechanisms of biopower include "forecasts, statistical estimates, and overall measures" and are designed to govern the body politic (246). Foucault's conclusion paints a grim picture of total state control: "We are, then, in a power that has taken control of both the body and life or that has, if you like, taken control of life in general — with the body as one pole and the population as the other" (253). Rather than the nation-state ceding power following the dissolution of monarchial sovereignty, Foucault argues instead that sovereignty is subsumed in disciplinary

\footnotetext{
${ }^{8}$ For a thorough delineations of the influence of Foucault's biopolitical theories, see Timothy C. Campbell's Improper Life. Minneapolis, MN: University of Minnesota Press, 2011. Print. See Also Vanessa Lemm and Miguel Vatter's edited collection The Government of Life. NY: Fordham University Press, 2014. Print.
} 
power and biopower. Through this merger, citizens confer sovereignty onto the state in exchange for the quality of life the state pledges to safeguard.

While the rule-by-merger of disciplinary power and biopower purports itself to be rule based on peace and civility and promises to safeguard and promote the health and wellbeing of its citizenry - a government to serve the people rather than a people to serve the governmentFoucault notes that the disciplinary-biopower epoch (late $18^{\text {th }}$-century to the present) has produced the bloodiest wars in history and has been plagued by genocide, civil wars, imperialism, and racism. Foucault attributes the violence of the biopolitical era to biopower's reliance on perpetual war as a justification for the expansion of state power to governing life itself.

Foucault asserts that as the old matrix of monarchial sovereignty no longer provides a satisfactory justification for state power, a new matrix has been in play since the birth of the nation-state to justify the biopolitial expansion of state power to govern the population. Drawing from Nietzsche, Foucault theorizes this matrix to be the perpetuation of continuous war. Nationstates are born of war and revolution (50). Rather than the peace of law emerging from the battlefields, Foucault suggests that "peace itself is a coded war" (51) and "Law is not pacification, for beneath the law, war continues to rage in all the mechanisms of power, even in the most regular. War is the motor behind institutions and order. In the smallest of cogs, peace is waging a secret war" (50). A backdrop of perpetual war performs two key functions. The first and most explicit is the justification for what Georgio Agamben terms state-of-exception suspensions of individual rights (State). Secondly, war fuels nationalistic rhetoric and citizen loyalty to the state, ultimately resulting in the creation of State Racism, or "a racism that society will direct against itself, against its own elements and its own products” (Society 62). Through 
State Racism, states not only maintain perpetual interstate wars with foreign enemies, but also wage continuous civil war against individuals who deviate from constructed societal norms.

The external other, the foreign enemy, threatens the state at its border or periphery, while the internal other resides within the state's boundaries and threatens the "health" of the state from within. While external enemies are relatively easy for the state to dehumanize through propaganda, ethnic racism, and geographical distance, identifying and defining internal enemies requires the state to turn against its own, as the internal enemy is "a race that is permanently, ceaselessly infiltrating the social body, or which is, rather, constantly being re-created in and by the social fabric" (Society 61). The creation and institutionalization of internal enemies relies on a system of norms, or standards of "normal" against which members of the state are measured (Discipline; Society). Whether the norm measures sanity, health, sexuality, ethnicity, class, or ideology, the use of norms to distinguish those within from those outside creates a "binary rift within society" that splits a "single race into a superrace and a subrace" (Society 61). ${ }^{9}$ This splitting of the state into two "races" feeds an ongoing civil war that is "waged not between races, but by a race that is portrayed as the one true race, the race that holds power and is entitled to define the norm, and against those who deviate from that norm, against those who pose a threat to the biological heritage" (61). The long-term implications of the "racist thematic" of the nation-state is the transformation of racism from "the struggle between one social group and another" to a "global strategy of social conservatism" in which state power relies on "the internal racism of permanent purification" as "one of the basic dimensions of social normalization" (62).

\footnotetext{
${ }^{9}$ While biological racism incorporates and builds from historical legacies of colonial (epidermal and ethnic) racism, it also adds mental and physical health, genetics, sexuality, and reproduction as markers of race and demarcations of "us" and "other." Those marked "other" by disease, genetic abnormality, sexual deviancy, criminality, mental illness, poverty, and/or epidermal race and ethnicity, become enemies of the state in a biopolitical race war which seeks to eliminate all potential infections and contaminations of the privileged population group
} 
Foucault's descriptions of biopower offer helpful tools for delineating the variety of cultural trends to which biopolitical cyborgs respond, but his theories offer little hope of a brighter future for the cyborg. This is the point at which the biopolitical cyborg departs from Foucault's "natural body" and gestures toward potentialities of cyborg existence that more closely align with Donna Haraway's ironically liberated cyborg vision. Haraway pulls from cyborg tropes in feminist science fiction to both formulate and articulate her "blasphemous" and "ironic faith" in the cyborg's potential to "suggest a way out of the maze of dualisms in which we have explained our bodies and our tools to ourselves" ("A Cyborg" 149, 181). Citing works by Cherríe Moraga, Joanna Russ, Octavia Butler, Vonda McIntyre, and others, Haraway asserts, "These are our story-tellers exploring what it means to be embodied in high-tech worlds. They are theorists for cyborgs" (173). The cyborg images in novels by these authors open up the fate of the cyborg beyond the apocalyptic vision of "man in space" or "natural body."

As I mentioned earlier, Western origin myths of an original and organic wholeness engender a system of dualisms that "have all been systemic to the logics and practices of domination of women, people of color, nature, workers, animals" (Haraway “A Cyborg” 177). By rewriting origin stories as moments of hybridity between human and other, these authors are able to envision cyborgs who can not only escape "a dialectic of apocalypse with the other," but who, through their "intimate experience of boundaries" contain the potential to confront and challenge power systems on multiple fronts $(177,181)$. Haraway's manifesto thus proposes a second fate for the cyborg, one that doesn't end in apocalyptic horror and wholeness, and she grounds this potentiality in the cyborg's " "final' irony," that, while being the "illegitimate offspring" of Western power systems, "the cyborg has no origin story in the Western sense" $(150,151,150)$. Haraway attributes the cyborg's potential as a eutopian metaphor to this final 
irony: "The cyborg skips the step of original unity, of identification with nature in the Western sense. This is its illegitimate promise that might lead to subversion of its teleology as star wars" (151). Because of its hybrid origins, the cyborg "would not recognize the Garden of Eden; it is not made of mud and cannot dream of returning to dust" (151). Haraway believes that patriarchal militarism has outsmarted itself by creating subjects whose hybrid natures expose humanism's foundational binaries to be empty illusions. The merger of man + machine may be the child of patriarchal capitalism, but "man" has given birth to a hybrid he can no longer control. As his means of control were justified by the hierarchical division of man/machine, ironically, his hybrid creation is not bound by his own rules. Thus, Haraway places her bets on cyborgs' eutopian potentials to defy their intended purposes and dismantle, rather than shore up, humanism's foundational binaries.

Haraway describes the division between the apocalyptic "man in space" and the "ironically liberated" cyborg as a difference in perspective: "From one perspective, a cyborg world" narrates militarism and patriarchal capitalism's successful implementation of a "final grid of control on the planet" (154). However, "from another perspective, a cyborg world might be about lived social and bodily realities in which people are not afraid of their joint kinship with animals and machines, not afraid of permanently partial identities and contradictory standpoints" (154). Haraway's manifesto promotes this second perspective, and even directly critiques Foucault's notions of biopower for his failure to imagine alternative fates for his disciplined natural body. ${ }^{10}$ However, she stresses the importance of keeping both cyborg images in view:

\footnotetext{
${ }^{10}$ Haraway describes Foucault's formulations of biopower as giving a name to "a form of power at its moment of implosion" (footnote 12). Earlier, she refers to his biopolitics as "a flaccid premonition of cyborg politics, a very open field."
} 
The political struggle is to see from both perspectives at once because each reveals both dominations and possibilities unimaginable from the other vantage point. Single vision produces worse illusions than double vision or many-headed monsters. Cyborg unities are monstrous and illegitimate; in our present political circumstances, we could hardly hope for more potent myths for resistance and recoupling. (154)

I ultimately find that this is the power and potential of biopoltical cyborgs; they allow us to hold both perspectives at once. Critical dystopias invite us to stare into the darkness and become ruinreaders of our futures.

By reading the evolution of critical-dystopian cyborgs within the contexts of concurrent biopolitical trends, we can come closer to answering why progressive authors of novels meant to caution against neoliberalism and conservatism routinely depict hybridity and cyborganization as an initial hindrance to eutopian futures of peace and equality. I have structured this dissertation to follow what I envision to be a continuum of biopolitical cyborg manifestations. While all of the cyborgs I examine demonstrate the authors' attempts to "see from both perspectives at once," some figures embody more of Haraway's ironic liberation than others. One pole of the continuum is occupied by cyborgs who primarily align with Foucault's "natural body" formulation. Though these characters ultimately gesture to the possibility of using their hybridity to contest reigning power systems, all hope is relegated off-page by the novels' ambiguous endings. The other pole is occupied by cyborgs whose eutopian glimmers are more apparent within the novels' pages. Readers get to see these characters begin to lay claim to their hybridity and use it to contest the status quo. 
In Chapter 1, I provide a taxonomy that explores four common manifestations of biopolitcal cyborgs—-mother-soldiers, soldier-cyborgs, bare-life-cyborgs, and Lilith's-childrenand link each figure to real-life twentieth- and twenty-first-century biopolitical trends. In each consecutive chapter, I offer an in-depth analysis of one of the four figures. In Chapter 2, I read the handmaids of Margaret Atwood's The Handmaid's Tale as mother-soldiers. I turn to Lois Lowry's The Giver in Chapter 3 in order to examine the ways Jonas and his fellow citizens are created as soldier-cyborgs and conscripted into biopolitical wars they cannot see. In Chapter 4, I analyze the character of Emiko from Paolo Bacigalupi's The Windup Girl as an exemplary barelife-cyborg figure. Finally, I turn to Octavia Butler's Xenogenesis Trilogy in Chapter 5. All three novels in the trilogy feature biopolitical cyborg figures. The Oankali race align with soldiercyborg iconography. Lilith, the protagonist of Dawn, is forced into a mother-soldier position by the Oankali alien race, and her first human/Oankali son, Akin, is relegated to a bare-life-cyborg status. However, it is her first third-sexed ooloi child, Jodahs, the protagonist and narrator of Imago, who embodies the most potential for envisioning and materializing a more eutopian future. Jodahs defies both male/female and human/nonhuman categories and, because the ooloi sex are master genetic engineers, literally possesses the ability to create a new kind of being. I read Jodahs as a Lilith's-children figure who reminds us that a better world is possible, but getting there may require us to relinquish human origin stories and embrace posthuman possibilities. 


\section{Chapter 1}

\section{Four Figures of Biopolitical Cyborgs}

"All that separates, whether of race, class, creed, or sex, is inhuman, and must be overcome."

-Kate Sheppard

The above epigraph, a quote from one of New Zealand's most prominent suffragettes, captures the inherent risk of any attempt to classify life—people, cyborgs, posthumans. I recognize the irony of labeling and categorizing types of hybrid life in a project that ultimately promotes hybridity as a liberating force capable of collapsing boundaries and challenging social stratifications. To classify is to place limits around, to bind, and constrain. In providing a taxonomy of biopolitical cyborg figures, it is not my intention to write prescriptions for interpreting these complex figures and the cultural work their authors are attempting. Rather, by highlighting four thematic trends found in many critical dystopian novels, my aim is to offer fresh ways to decode the apocalyptic ruins these cyborg figures inhabit. My hope is that this taxonomy will help us to better identify the specific targets of critical-dystopian authors' social critiques in order to better heed their warnings. The cyborgs I examine, like all boundary dwellers and liminal creatures, are not loyal to the categories I impose. Likewise, many of the characteristics I identify as features of biopolitical cyborgs are adaptations of, and pay homage to, earlier cyborg images. Though classification can separate, as Kate Sheppard so eloquently reminds us, it can also help us to focus on the commonalities between otherwise different things. In the case of biopolitical cyborgs, giving names to the myriad ways critical-dystopian authors envision state and corporate governance of "life in general" reveals the ways these stories work together to tell a more complete story of how our lives are already governed and designed by forces that are often invisible to us. Perhaps if we learn to read biopolitical cyborgs as maps of 
how we got here, we will also find that they can point us towards uncharted and unfamiliar elsewheres.

\section{Mother-Soldiers}

At the Air Force One Pavilion of the Ronald Reagan Library on the evening of September 16, 2015, as Reagan's presidential plane loomed in the background, eleven Republican presidential candidates stood behind eleven evenly-spaced podiums, lapels properly adorned with American Flag pendants, eager to perform their prescribed roles in the spectacle of nationally-televised debate. For three hours, the candidates interrupted and insulted each other in a fight for airtime, each hoping to convince the base of a fiercely divided GOP that he or she is the candidate most in tune with the party's current atmosphere. The evening's themes, questions, red herrings, and quarrels can be reduced to two recurrent topics: the ongoing War on Terror and defunding Planned Parenthood. Amidst heated arguments over how the US should respond to the UN's Nuclear Deal with Iran, Vladimir Putin's aggression, Bashar al-Assad's dictatorship, and the spread of ISIS, the moderators' questions routinely returned to the topic of whether or not particular candidates supported a temporary shutdown of the federal government in order to reject any budget plan that included funding for Planned Parenthood.

Carly Fiorina, largely considered to be the night's winner by debate analysts, used her allotted speaking time to juxtapose US involvement in the Middle East and Planned Parenthood's abortion services by what she sees as their commonality: "Dana, I would like to link these two issues, both of which are incredibly important, Iran and Planned Parenthood. One has something to do with the defense of the security of this nation. The other has something to do with the defense of the character of this nation" (emphasis added, $C N N$ ). Fiorina's statement 
succinctly captures the fear-based emotional charge of the 2016 GOP platform, which insisted on the precariousness of the nation's future in the face of imminent attack by Islamic terrorist organizations and foreign dictators, as well as persistent moral attacks from within by domestic enemies who are aborting the nation's future citizens. While the details have changed, Fiorina's merger of the dual threats of war and women's rights parrots tenets of conservative politics institutionalized after the passage of the $19^{\text {th }}$ Amendment, a merger the Republican Party solidified into its platform during Reagan's 1979 presidential campaign. Since Reagan's presidency, those most dedicated to neoliberal economics have propagated a doctrine that Christianity, the patriarchal nuclear family, a strong military, and a free market are the best defenses against foreign and domestic threats alike.

The first manifestation of biopolitical cyborgs, the mother-soldier, is a citizen of a state at war whose status as both a woman and a citizen doubly binds her to the will of the state by the future citizen-soldiers she represents. Mother-soldiers often don't appear to be very cyborgian at all as mother-soldiers do not always undergo a bodily cyborganization. Chris Hables Gray defines the cyborg as "a self-regulating organism that combines the natural and artificial together in one system" (Cyborg Citizen 2). Gray's definition highlights two features of the cyborg that resonate with Foucault's biopolitical "natural body" and that also appear in mother-soldier images: the artificial is not limited to technoscience and the goal of cyborganization is selfregulation. Foucault's representative body-machine complex is a soldier. In Foucault's metaphor, the nonhuman/machine element of Foucault's body-machine complex is a disciplinary mechanism. In other words, the "machine" being hybridized with the "natural" is a system of power. Because the soldier can put down his gun, the soldier's physical body has not been fully cyborganized; rather, the military has hybridized personal agency with disciplined thought to 
produce self-regulating soldiers. Likewise, the mother-soldier is a cyborgian amalgam of two disciplinary mechanisms, motherhood and citizenship. Significantly, state implementation of this hybrid disciplinary machine is justified and fueled by war. Two theoretical perspectives provide a vocabulary for assessing the disciplinary power of mother-soldier hybridity in the Reagan era: Foucault's concepts of perpetual war and State Racism, and Lauren Berlant's formulations of fetal motherhood.

Biopolitical programs are necessarily nationalistic, as they bring individuals into a formation of a national, collective body, and as Anne McClintock asserts, "all nationalisms are gendered" (61). Mother-soldier cyborg images enliven Foucault's biopolitical discourse by emphasizing that attempts to regulate life itself necessarily manifest as repressions to the individual reproductive body. Further, biopolitical systems that develop, or emerge, from patriarchal power structures will inequitably exercise biopolitical power on the bodies of its female citizens by reducing women's civic worth to their reproductive potentials. Lauren Berlant's concept of "fetal motherhood," a phenomenon she claims culminated with Reagan's administration, highlights the function of the mother-soldier within civil wars waged by superrace norms against the subrace others.

Berlant cites the effects of Reaganite politicization of the private sphere, noted by conservative backlashes to civil and women's rights movements, as the source of fetalmotherhood iconography. Reagan's campaign, and subsequent administration, brought the US's legacy of conflating female citizenship with motherhood to the political forefront by convincing "a citizenry that the core context of politics should be the sphere of private life" (Berlant 3 ). Reagan paradoxically advocated reducing the federal government and ramping patriotic nationalism, seeking "to shrink the state while intensifying identification with the utopian 
symbolic "nation"” (3). This was done through the "privatization of citizenship" which established an American norm by propagating nostalgic iconography of "a normal, familial America that would define the utopian context for citizen aspiration" (3). Reaganite familycentric nationalism not only renders a person "American" or "un-American," insider or outsider, based on her adherence to the "traditional family" norm, but also insists that private, intimate acts will ultimately secure or destroy the nation's future (5).

Reagan's split emphases on the past and the future met in the icon of the unborn fetus. He contended that Americans must return to the security provided by the Christian nuclear family in order to protect the future citizen — the fetus and the child—from impending threats of secular statism. This "not yet" American has "not yet" been traumatized by America's present culture of sexualization and secularization. As such, this incipient American is the new, unmarked iconic citizen who must be protected. In the midst of heated debates regarding abortion and women's reproductive rights, the Reaganite idea of the fetus-as-ideal-citizen positioned women's personal, private reproductive choices as political acts. Crucial to this transformation was the propagandized image, first in popular media and then incorporated into Reagan's campaign, of the unborn fetus as a symbol of the ideal future citizen in need of the state's protection. ${ }^{11}$ Such fetishizing of the fetus diminishes the pregnant mother's political

${ }^{11}$ Berlant's examples of fetus iconography span the 1960s-1980s and include: pro-life bumper stickers reading "Support Our Future Troops!" and "Abortion Is Destroying America's Future... One Life at a Time"; a public service announcement warning of the dangers of using drugs while pregnant that asks the mother to choose the health of her fetus over the "pleasure" of her crack pipe; a print ad featuring a photograph of a second-trimester fetus overlaid with the text "She can make a tiny fist, get hiccups, suck her thumb, feel pain, Yet she can be legally put to death by abortion at any time until the day she's born"; LIFE magazine's exposé on "How Life Begins"; a doll with a fetus floating in its clear abdomen and a cigarette hanging from her mouth, named "Smokey Sue Smokes for Two"; anti-abortion documentaries, such as The Silent Scream, Eclipse of Reason and Let Me Live; Reagan's 1983 book Abortion and the Conscience of the 
agency, resulting in a phenomenon of "fetal motherhood" in which "the pregnant woman becomes the child to the fetus, becoming more minor and less politically represented than the fetus, which is in turn made more national, more central to securing the privileges of law" (85). When a fetus represents the ideal citizen and the future of the state, safeguarding the fetus takes political precedence over the mother's right to make reproductive decisions. Further, these prolife tactics advance the agenda of Reaganite privatized citizenship by suggesting that women's reproductive choices impact the entire nation. This is most clear in the "Support Our Future Troops" anti-abortion bumper sticker Berlant cites, which implies the very survival of the nation is at stake in abortion debates (101).

Though the literary figure of the critical-dystopian mother-soldier emerges in the 1970s and 80 s, largely in response to public discourses about IVF and women's reproductive rights, the figure invokes a long history of state co-option of motherhood as a disciplinary mechanism, particularly at times of war and specifically in America. ${ }^{12}$ Social norms and civic responsibilities required of the American mother have evolved as women have gained more political power through enfranchisement and civil rights advancements; nevertheless, the state's sustained rhetoric of war and patriotic duty have inextricably bound the two roles - citizen and motherthroughout America's history. As a citizen of a perpetually warring biopolitical state, the American mother is a conscripted citizen-soldier tasked with defending threats to Americanism from both within and outside of the nation's geographical borders.

Nation; and a pro-life ad titled "Diary of an Unborn Child" that closes with the entry, "DECEMBER 28-Today my mother killed me" (101; 111; 114; 126).

${ }^{12}$ See Rebecca Jo Plant's book, Mom, which traces the transformation of American ideals of motherhood from the pre-WWI idea of "mother love" to the post-WWII turn to "mother blame." See also Kristen Marie Delegard's Battling Miss Bolsheviki, which examines the period following the passage of the $19^{\text {th }}$-Amendment and how women, post-enfranchisement, perceived their civic responsibilities and how these perceptions were shaped by propagandized threats of Russian infilitration. 
The mother-soldier embodies the ways women in biopolitical systems are dually subjugated by their hybridized roles as mothers and soldiers. Women are conscripted into biopolitical wars as mothers and assigned duties of either bearing and raising normalized children or intentionally preventing pregnancy, depending on the woman's superrace/subrace status as well as considerations of the body politic's birth and death rates. In dystopian speculations, state co-option of women's reproductive process is often overt, forceful, and complete. Oppressive state systems justify their "temporary," state-of-exception control of women's fertility by deploying a rhetoric of war. Using threats of perpetual war as a justification for state oppression has long been a convention of the dystopian genre-most often used to justify food rations, curfews, strict surveillance, etc.- - and critical-dystopias demonstrate the additional potential for oppressive states to use war rhetoric to appropriate control over fertility "for the good of the nation." As a nation's children are its symbolic and literal future, a state-ofexception threat, whether real or fabricated, gives dystopian states the leverage needed to declare eminent domain over its citizens' fertile bodies.

The handmaids of Margaret Atwood's The Handmaid's Tale are exemplary manifestations of mother-soldiers. Set in the former United States, Atwood's Gilead results from a successful revolution by a radical conservative faction. The novel demonstrates Berlant's assertions that when bearing children becomes a woman's civic duty, the state subjugates the woman to her unborn children in a gendered nationalism that values the idealized future citizens she may bear over her own individual and political worth. Gilead suffers from an infertility crisis. The Gileadian State attempts to survive the crisis by forcing young, fertile women who belong to Gilead's newly constructed subrace to become surrogate birthmothers for infertile couples of the ruling class. The fertility crisis has driven the founders of Gilead to separate 
pregnancy and childbirth from motherhood, as they need fertile women to give birth, but they also do not trust women who deviate from Gilead's strict social norms to raise the new state's future soldier-citizens. Gilead coerces compliance to its authoritarian control of women's fertility by propagating the threat of interstate wars with other nations as well as violent conflicts with rebel factions within Gilead's borders. This threat of perpetual war complicates Berlant's fetalmotherhood image by hybridizing motherhood and soldierhood. Women who refuse to comply with Gilead's reproductive agenda are not only regarded as deviants, but are deemed traitors and punished as such. Atwood's mother-soldiers demonstrate the ways biopolitical states can wield hybridity as a disciplinary mechanism that strengthens, rather than dismantles, humanist power structures. Beginning my taxonomy of biopolitical cyborgs with an image of a hybrid citizen that is not cyborganized with machines, animals, or aliens foregrounds the disciplinary potential of biomedical posthuman programs featured in subsequent manifestations of biopolitical cyborgs.

\section{Soldier-Cyborgs}

The second manifestation of biopolitical cyborgs, the soldier-cyborg, adapts Huxley's World State citizens and Clynes and Kline's cyborg super-soldiers within the contexts of the “test tube baby boom.” Like Huxley's brave new world, soldier-cyborgs are genetically modified or artificially augmented citizen-soldiers designed to comply with state agendas. Responding to advances in reproductive and genetic technologies, authors of soldier-cyborgs in critical dystopias subsume the artificial beneath the flesh, making it difficult for readers to distinguish the degree to which these characters have been cyborganized. Veiling cyborgian processes also obscures the militaristic motivations behind posthuman programs in these stories. Whereas 
images of bionic super-soldiers wield their weaponized prosthetics on the front lines of interstate battles, critical-dystopian soldier-cyborgs often are not aware of their roles in biopolitical wars.

Burying the artificial beneath the flesh subverts the narrative trajectory of earlier literary cyborg and android images that first present audiences with the machine, highlighting the character's inhuman features, before guiding the reader through plots that reveal the seemingly inhuman characters' humanity. Conversely, soldier-cyborgs initially appear to be "natural" humans, to both themselves and to readers, but their humanity is called into question as the narrative reveals that the characters have been genetically designed and/or created by means other than unassisted male-female procreation.

The refusal to disclose the degree to which these characters have been cyborganized ultimately forces the reader to decide whether or not the characters are "human" based on criteria other than the natural-to-machine ratio of their bodies' composition. Soldier-cyborgs thus introduce a thread running through all manifestations of biopolitical cyborgs: the question of how we define humanity and conceive of being human. Most often in soldier-cyborg narratives, humanity is conflated with the ability to make autonomous choices and take self-beneficial actions that are not in accordance with state agendas. These narratives typically begin with the point-of-view of a character who is unaware of her cyborg origin story. She eventually discovers that she has been, at least partly, designed, and begins to question how much of her personality, desires, and actions are dictated by her creators. Like the natural body of Foucault's soldier, the soldier-cyborg perceives her designed body to be natural and her choices to be autonomous; however, as she discovers the artificial elements of her body, she begins to question the autonomy of her actions and choices. Typically, these cyborg stories culminate in the cyborg rebelling against her design and making choices that do not comply with her biopolitical state's 
doctrines. This relationship between autonomy and genetic design allows for a reading of biomedical cyborganization as a disciplinary mechanism, as characters who have been designed to comply awaken to their own cyborganization and can begin to choose to rebel against their makers.

The impulse to design citizens often arises from a state's well-intended desire to quell social and political unrest through science. Often, this desire is expressed in rhetoric of peace. Foucault claims that "peace itself is a coded war" as beneath the surface of peace a law, "war continues to rage in all the mechanisms of power, even the most regular" (Socitey 50). Therefore, cyborgs born of wars coded as peace function as soldiers fighting wars they often cannot see. Soldier-cyborgs speculate that posthuman programs designed to enforce ideals of peace and equality will most often result in faux-eutopias of citizens who are blind to the mechanisms of power controlling their lives. Chapter three provides an analysis of one such society in Lois Lowry's 1993 The Giver. Lowry's Community in The Giver is perhaps the most fully realized dystopia I analyze as the state system maintains absolute control without the citizens perceiving or resisting their oppression. The Community is perfect on the surface; there is no violence, crime, hunger, homelessness, class divisions, fear, or environmental catastrophes in the Community. However, the Community maintains this homeostasis by completely controlling population rates and life spans. Genetic modifications are used to regulate hair, eye, and skin color to ensure "Sameness" and members of the Community can no longer see color. The Community's childbirth processes are never fully explained in the novel and traits such as the inability to see color are described as "choices" the Community made "back, and back, and back," suggesting that citizens are acting as soldier-cyborgs whose "choices" benefit the Community's biopolitical agenda. 
Lowry's Community of seemingly inhuman cyborgs suffers from living in a technological world without an understanding of the ways technology has been used to diminish their ability to choose how to live their lives. Clynes and Klines refer to cyborganization as "participatory evolution," meaning humans take an active role in the future trajectory of human evolution by melding artificial and natural systems. In Cyborg Citizen, Chris Hables Gray asserts that participatory evolution that isn't met with "participatory government" will most likely exacerbate today's social injustices and state oppressions (3). James Hughes makes a similar argument, warning "becoming more than human can improve all our lives, but only new forms of transhuman citizenship and democracy will make us freer, more equal and more united" (xii). Participatory government in the age of the cyborg demands that citizens understand, interact with, and have equal access to the technologies shaping their lives. Soldier-cyborg figures enforce Gray and Hughes's assertions by aligning humanity with choice, and choice with the knowledge of power mechanisms influencing our choices.

\section{Bare-life-Cyborgs}

Whereas soldier-cyborgs arise from well-intentioned desires to use technology as a solution to, or naturalization of, longstanding systemic injustices, bare-life-cyborgs are manifestations of worlds in which biopowers implement posthuman programs that intentionally exploit legacies of racism and sexism in their creation of cyborgian transhumans. In these novels, powerful states and corporations wield genetic and biomedical technologies to create cyborgs whose transhuman DNA excludes them from human rights protections in constitutional democracies, carving a space for legal slavery in liberal-democratic states. These novels implicitly respond to Diamond v. Chatrabary (1980), the US Supreme Court decision that 
expanded patent laws, which previously excluded patents of any form of life, to include "a live human-made microorganism," granting General Electric sole ownership of a bacterium designed to clean oil spills (Diamond). While the court's decision made clear that patent expansions stopped short of covering human beings, as patenting humans would violate the Thirteenth Amendment, the decision neglected to address "genetically engineered human tissues, cells, and genes," and set a precedent for corporate ownership of a variety of man-made life forms (Gray 117). Since Diamond v. Chakrabarty, corporations and universities have received patents covering "transgenic nonhuman mammals," (116) cultured human cell lines, and most frequently, genetically modified plant seeds (Gray 113-127). Bare-life-cyborgs extend dystopian speculations of patenting life to the creation and marketing of transgenic human/nonhuman beings.

Bare-life-cyborgs bring to life Georgio Agamben's formulation of bare-life/politicalexistence binaries in biopolitical states. Amplifying Foucault's subrace/supperace stratification, in which the subraced other maintains her citizenship within the biopolitical state, Agamben's bare-life subject is a person who, though living within a state's borders, falls outside of a state's legal protections. Natural, inalienable rights afforded to citizens are denied to bare-life beings, and bare-life subjects can be killed with impunity (Homo Sacer 71-75). Bare-life-cyborg manifestations in critical dystopias are most often transhuman products created by biotech corporations or state agencies. Because these novels depict corporations and private enterprise as equally powerful, or more powerful, than state systems, they narrate a transition from biopolitics to bioeconomics, or "the process by which the population of people whose health the state was meant to foster [are] displaced by the aggregate understood as the economy itself, an entity whose health the people are now meant to serve" (Vint "Introduction" 163). In other words, the 
health of the market supplants the health of the body politic, resulting in legal protections for corporations at the expense of citizens and consumers. Rather than the all-powerful biopolitical state governing populations, the bioeconomic market, now trafficking in patented life processes and products, commodifies life itself. Unlike biopolitics, which gauges the health of the population based on its homeostasis, bioeconomics equates market health with exponential, limitless growth. In the world of bioeconomics, the dystopian potential of state overreach is displaced by deregulated, all-powerful corporations manufacturing and monopolizing biocommodities.

Bare-life-cyborg figures also forewarn of ways posthuman programs can exploit humanism's hierarchical binaries, particularly gender and race stratifications. Despite the binarycollapsing potential of cyborganizaiton, many scholars warn that posthumanist enthusiasts have a tendency to reinscribe humanist ideals onto posthumanist fantasies by viewing the body as a hindrance to human liberation and no longer necessary to a cybernetic or technological existence. Dan Bruiger, for instance, suggests that posthumanism pursued through technoscienceparticularly the melding of mind with machine — expresses characteristically masculine fantasies of transcendence, of god-like creative powers and domination of nature. He warns that enthusiasts who view all biotechnical melding of man and machine as unquestionably progressive tend to disregard the body and forget that "we are inescapably embodied and part of nature" (16). Posthumanist ambitions that disregard embodiment risk reinforcing, rather than dismantling, gender and class hierarchies. Bruiger and Elizabeth Grosz's insistence on an embodied posthumanism resonates with a growing body of writers, such as N. Katherine Hayles and Thomas Foster, who suspect the lure of immortality and disembodiment expressed by many posthumanist enthusiasts is an echo of, rather than a departure from, tenets of patriarchal 
humanism. Such disembodied fantasies leave traditional gender conceptions intact. Ann Balsamo, for example, argues that the history of popular cyborg iconography, which depicts the cyborg as a product of militarism and masculine fantasy, tends to perpetuate, rather than challenge, long-standing gender binaries. She notes that science fictional cyborg images often depict male cyborgs as more machine than man, thus privileging the mind and culture over body and nature. Conversely, female cyborgs are often more flesh than machine and more emotive. Though female cyborgs "challenge the relationship between femaleness and technology," they also often “inhabit traditional feminine roles—as object of man's desire and his helpmate in distress" $(149 ; 148)$.

Despite the cyborg's checkered past, some feminist thinkers still see its potential as a metaphor for promoting social change. Sherryl Vint, for example, also criticizes disembodied fantasies and argues that unless posthumanist projects take embodiment into account, their effects will be decidedly dystopian. In their dismissal of the body and nature by privileging mind and machine, champions of disembodied posthumanism threaten to dismiss all beings who have traditionally been aligned with nature and body—people of color, lower classes, and women. To address the problem of the Cartesian split haunting posthumanist discourses, Vint turns her attention to the human/nonhuman binary in her call for an "ethical posthumanism" (Bodies 13; 171-90). Drawing from Vicki Kirby, who suggests that the posthuman "crisis of the subject" in much science fiction is best "understood as a crisis of species identity," Vint views man/animal and man/machine distinctions as coded expressions of the mind/body split that "again jettisons the body from subjectivity" by aligning mind/male characteristics with humanness and body/female characteristics with non-humanness (189). In a world where binaries between man and machine, and man and animal, are collapsing, Vint suggests that the hierarchies traditionally 
established in man/machine and man/animal binaries have held firm by shifting to a human/nonhuman binary that still promotes the hierarchical position of the white, upper-class male by defining this position as the standard of humanness. In a biotech world, humanist ideals must be attacked from a human/nonhuman position. Vint's ethical posthumanism again redeems the cyborg's eutopian potential as she sees science fiction as providing "a space for narrating agency for non-human subjects" (189). If, as Vint believes, nonhuman is code for female, SF nonhuman cyborgs, even as dystopian figures, have the potential to narrate agency for female subjects in patriarchal systems.

The world depicted in Paolo Bacigalupi’s 2009 The Windup Girl exemplifies the global transition of power systems from biopolitical states to hyper-capitalist bioeconomies, and his "New People" forecast dark ends to the legal patenting of genetically modified lifeforms. However, his exemplary cyborg figure, who is the victim and product of a humanistposthumanism pursued from the context of a global, hyper-capitalist bioeconomy, ultimately negotiates for personal and political agency by disrupting her society's human/nonhuman hierarchy. Set in $23^{\text {rd }}$-century Thailand, Bacigalupi's futuristic world suffers from global famine resulting from human-induced environmental devastation. Calories have become currency and all-powerful corporations have turned to the genetic engineering of plants, animals, and transhumans to sustain life on the damaged planet, including using advanced technologies to design transhumans to fulfill certain roles. For example, agricultural workers are created with extra arms to increase productivity and conserve caloric energy and sex slaves are engineered to physically and emotionally crave subjugation to a master. Though designed and created as commodities in bioeconomies, New People still serve a particular biopolitical function. According to Foucault, biopolitical power justifies itself by promising to protect its superrace 
citizenry from threats posed by internal subrace contagions. As this justification would no longer hold if the subrace was ever fully eradicated, the biopolitical state must continuously generate a subrace in order to maintain a superrace/subrace civil war (SMBD). In Bacigalupi's world, the creation of transgenic New People, beings whose DNA disallows them to challenge their legal status, offers biopolitical states the potential to continually generate a transgenic subrace.

Like soldier-cyborgs, bare-life-cyborgs challenge readers' assumptions about the definitions and parameters of humanity. However, whereas soldier-cyborgs (re)gain their humanity by learning to overcome the artificial components that work to discipline their thoughts and actions, bare-life-cyborgs come into their humanity by learning to embrace and wield their nonhuman characteristics to assert agency. Bacigalupi’s exemplary New Person, Emiko, demonstrates this transition when she learns that her transgenic DNA has given her superhuman strength and speed. She ultimately uses these abilities to kill people who threaten her life. The bare-life-cyborg's transition from in/nonhuman to human opens a eutopian space that, echoing Haraway's vision of "ironic liberation," suggests the cyborg can liberate herself by making claim to her hybridity.

\section{Lilith's-children}

The fourth manifestation of biopolitical cyborgs I discuss is Lilith's-children. Lilith'schildren are the next-generation results of posthuman participatory evolution. In other words, they are the decedents of mother-soldiers, soldier-cyborgs and bare-life-cyborgs. Lilith'schildren open a space for eutopian possibilities that there is a way out of this biopolitical and bioeconomic darkness. However, there's a catch: the solution to injustices and oppressions inherent to human power systems requires the extinction of human beings as we are now. 
Lilith's-children are capable of creating worlds that humans cannot imagine. Often, their ability to think outside of binary and hierarchical structures is a result of the inability to reduce posthuman populations to two sexes or discrete races and ethnicities. In this way, Lilith'schildren resonate with Ernst Bloch and Fredric Jameson's insistence that human attempts to design and create a eutopia will always fail, as human architects cannot separate themselves from their legacy of binary and hierarchal thinking. Lilith's-children suggest that humans cannot fully conceive of a posthuman future. Lilith's-children most fully capture the ironic liberation envisioned by Haraway. As their name implies, the potentials for Lilith's-children to envision and move toward systemic change emerge from their ability to reject and rewrite Western origin stories based on a mythic wholeness. While Lilith's-children occupy positions closer to the ironically liberated pole of Haraway's cyborg continuum, they still allow us to view both cyborg poles at once by featuring the biopolitical apocalyptic settings common to critical dystopias.

My term “Lilith's-children” is indebted to Octavia Butler's Xenogenesis Trilogy, published as one volume under the title Lilith's Brood. The trilogy opens aboard an Oankali spaceship orbiting just beyond Earth's atmosphere two hundred and fifty years after a nuclear war between the United States and Russia brought humanity to the brink of extinction and rendered the earth uninhabitable. The Oankali, a three-sexed (male, female, and ooloi) alien species from a distant star system, have rescued the few humans who survived "the war" and are keeping them held in suspended animation while preparing the earth's environment for rehabitation. The Oankali describe themselves as "traders" who travel through various solar systems looking for genetically interesting new species to "trade" with. The Oankali are master genetic engineers who seek to interbreed with new species for the purposes of creating Oankali/trade-partner "construct" species designed with the best genetic traits of both groups. 
Dawn follows the story of Lilith Iyapo, an African-American woman the Oankali have chosen as the surrogate mother to all surviving humans as well as the first birthmother of humanborn construct children. Lilith resists her chosen role and is often perceived as a traitor by the humans she must teach. The novel closes as she discovers she has been impregnated with a construct child without her consent. The remaining novels tell the stories of two of her many construct children. Adulthood Rites follows the life of Akin, the first male human-born construct and Lilith's first son. As a hybrid living among Oankali and humans, Akin feels alienated from both groups and has trouble being fully accepted by either group. Though fated to a life on the periphery, he discovers that his position allows him to act as a mediator between the two species. He ultimately succeeds in negotiating for resister humans by convincing the Oankali to establish Mars as a home for humans who choose not to trade. Imago relays the story of Jodahs, the first human-born ooloi construct. Like Akin, Jodahs initially struggles to find a place as the first of its kind, but ultimately finds that its outsider status enables it to envision a world unimaginable to both its human and Oankali parents. As an ooloi, the sex responsible for "mixing" embryos during Oankali reproduction, literal architects of the species, Jodahs represent the eutopian possibility of creating a different, better future.

In essence, the trilogy speculates the future cyborganization of humanity through participatory evolution, as the Oankali believe that the new construct species will be superior to both Oankali and humans and thus better adapted for survival and longevity as a species. Despite the Oankali's instance that interbreeding will address humanity's hierarchical tendencies, evoking posthumanist optimism for a more equitable cyborgian future, the novels are full of conflict and dystopian sentiments as Butler makes use of mother-soldier, soldier-cyborg, and bare-life-cyborg tropes. Though Dawn and Adulthood Rites incorporate many of the 
reproductive, biomedical, and biopolitical themes found in The Handmaid's Tale, The Giver, and The Windup Girl—dystopian themes that closely align with Foucault's natural body—by granting her characters unusually long lifespans, Butler is able to move through longue durée dystopian results of biopolitical cyborganization in the these novels and introduce a posthuman eutopian potentiality in her concluding Imago. Her final protagonist, Jodahs, the progeny of oppressors, mother-soldiers, and soldier-cyborgs, is a third-sex human-Oankali hybrid capable of physical metamorphosis in response to emotional and environmental stimuli. His physical malleability represents the creation of a new people who are capable of structural change. As the first ooloi-sexed construct, Jodahs will be instrumental in the design of the human-Oankali construct species. Though the product of coercive genetic manipulation and childbirth processes, Jodahs's personal and political agency far surpasses that of its five human and Oankali parents. Significantly, Jodahs's story is the first in the trilogy told in first person, giving it editorial control over its own legacy.

Cathy Peppers notes that the trilogy demonstrates Donna Haraway's description of a “"cyborg' origin story" in that "Xenogenesis contests our culture's most powerful originary discourses (Biblical, biological, anthropological)" (48; 59). Like Haraway's vision of "illegitimate offspring" who are "exceedingly unfaithful to their origins," Jodahs can choose to defy its designed intent and create a world beyond human or Oankali imagination. Butler's characterization of Jodahs ultimately suggests that, over time, the subjects of oppressive biopolitical and humanist-posthuman programs may be able to finally rid themselves of humanist gender, race, ability, and class hierarchies and create a more just, albeit posthuman, future that their parents were incapable of imagining or accepting. Though we aren't given access to the ultimate fates of Jodahs's decedents, the trilogy that opens in the aftermath of a biopoltical 
human apocalypse closes with the an image of a renewed cyborgian earth, inhabited by posthumans, that closely resonates with Haraway's positive vision of "a world without gender, which is perhaps a world without genesis, but maybe also a world without end."

\section{Conclusion}

As the novels I examine demonstrate, biopolitical cyborg figures appear across criticaldystopian subgenres, from YA novels to extraterrestrial SF narratives. Though representations of these figures and their accompanying metaphorical functions vary widely, each speculates unintended, or purposefully hidden, consequences of cultural shifts towards hybridity to individual subjects living within biopolitical systems. In these novels, being human is aligned with political agency and personal choice, and the cyborg's humanity is challenged on these grounds. Biopolitical cyborganization is a disciplinary process intended to yield self-policing, compliant subjects. Rather than liberate the cyborg from constraining hierarchical binaries, hybridity initially functions as a double bind by further limiting the cyborg-subject's physical, social, and/or political ability to make autonomous, self-beneficial choices. Like the image of the shortsighted scientist celebrating the birth of his baby T-Rex, critical dystopian depictions of cyborgs ask readers to balance enthusiasm for technologies that alter the human body with a keen awareness of how bodies are already marked, stratified, and leveraged by states and markets.

When read together, these four variations of biopolitical cyborgs check and balance each other. Mother-soldiers showcase the ways gender and social norms inhibit individual expression when codified in law and strictly enforced, whereas Lilith's-children often struggle to form a personal identity when occupying liminal spaces outside of established male/female and human/nonhuman binary categories. Likewise, soldier-cyborgs stress the necessity of 
transparency in, and equal access to, genetic and biomedical technologies, whereas bare-lifecyborgs caution against impulses to clearly identify and label the intersections of human and nonhuman in posthuman persons. Collectively, these novels encourage a multifaceted study of the ways biotech has historically been, and continues to be, applied differently, and to different ends, among socially and politically stratified groups. These dark tales confront readers with a difficult question: if genetic and biomedical technologies have historically been used to shore up gender and race stratifications for biopolitical ends - the US's legacy of eugenics programs that targeted the poor and women of color vs. the cost of ARTs that help the "right kind" of person have a child — what rationale supports the hope that further technological progress will push us towards a more equitable and just future? These novels directly oppose James Hughes's optimistic supposition that, since the globe is consistently "becoming more equitable and more free," posthuman and transhuman projects will at best push us towards a better future or, at worst, be a neutral factor in our progress towards equality (51) and instead closely align with Chris Hables Gray's insistence that, though we cannot fully foresee all possible outcomes of our current actions, we must diligently, and as objectively as possible, examine our individual and cultural motives for pursuing posthuman futures (Cyborg 1-6).

Ultimately, these novels remind us to not get so distracted by thoughts of the future that we overlook or disregard the present. Their critical referent is the here and now, and their fictional protagonists suffer the results of uncritical pushes towards posthumanity that began in our time. In her most recent book, Donna Haraway insists that we live in troubled times and that we must "stay with the trouble." Staying with the trouble, in Haraway's words, counters two common responses to the social injustices and environmental crises we face today: "the first is... a comic faith in technofixes:... technology will somehow come to the rescue of its naughty 
but very clever children... The second response, harder to dismiss, is probably even more destructive: namely, a position that the game is over, it's too late, there's no sense trying to make anything better" (Staying 3). These contrasting responses to today's troubles share a common flaw: a myopic focus on the future at the expense of attending to the present: In urgent times, many of us are tempted to address trouble in terms of making an imagined future safe, of stopping something from happening that looms in the future, of clearing away the present and the past in order to make futures for coming generations. Staying with the trouble does not require such a relationship to times called the future. In fact, staying with the trouble requires learning to be truly present, not as a vanishing pivot between awful or edenic pasts and apocalyptic or salvific futures, but as mortal critters entwined in myriad unfinished configurations of places, times, matters, meanings. (1)

Read individually, the novels I examine in the coming chapters risk Haraway's admonishment of focusing on the future by attempting to prevent a looming crisis; however, read together, they insist that the trouble is here; the trouble is now. Attempts to avoid, rather than confront, today's troubles may only exacerbate the problems. Significantly, as critical dystopias, they also avoid a "game over" pessimism in their urgency to address the troubles of the here and now and their eutopian glimmers that insist upon the necessity of hope, of life after the apocalypse. A more equitable and just poshuman future is possible. But in pursuing such futures, we must, with diligence and intention, stay with the trouble. 


\section{Chapter 2}

\section{Mother-Soldiers in Margaret Atwood's 1985 The Handmaid's Tale}

"The book came out in the UK in February 1986, and in the United States at the same time. In the UK, which had had its Oliver Cromwell moment some centuries ago and was in no mood to repeat it, the reaction was along the lines of, 'Jolly good yarn.' In the US, however...it was more likely to be 'How long have we got?','

-Margaret Atwood, 2015

When I first began this project, Barack Obama was two years into his second presidential term. As an unprecedented number of candidates seeking the 2016 Republican nomination began throwing their names into the hat, each vowing to erase Obama's influence and return America to its "traditional values," many Americans perked up to the all-too-familiar echoes of life before Griswold v. Connecticut and Roe v. Wade embedded in conservative nostalgia. Two years later, as I put the finishing touches on a dissertation about contests for control of reproduction in hightech biopolitical states, Donald Trump and Mike Pence occupy the White House and Margaret Atwood's 1985 Handmaid's Tale (HT) “is the latest work of classic dystopian fiction to hit the Amazon Bestseller list since the presidential election" (Mayer). ${ }^{14}$ Hulu's television series adaptation of the novel debuts in April, and protesters around the globe carried signs referencing the novel during the January 21, 2017 Women's March on Washington: “The Handmaid's Tale is not an instruction manual"; "Make Margaret Atwood fiction again"; "Nolite te bastardes carborundorum." For many who oppose Trump's platform and the quick moves several red states have made to increase state governance of women's health since Trump's inauguration, the answer to the question posed in the above epigraph seems to be time is up.

I begin my exploration of biopolitical cyborgs in critical dystopian novels with what may seem to be an unlikely choice. Though $H T$ forefronts control of reproduction as a tool of

\footnotetext{
13 "Haunted by the Handmaid's Tale"

14 According to Anchor Books publicist Russell Perreault, “In the last year, we've gone up 60 percent. And since the election, it's been 200 percent increase in sales...Just this year alone, 2017, we've printed 125,000 copies of the book and since last November, 150,000 copies" (Mayer).
} 
authoritarian state oppression, the novel does not feature advanced reproductive and genetic technologies. In fact, the reactionary society Atwood creates distrusts biomedical tech and outlaws the use of most existing reproductive medicines and ARTs. The cyborg characters in $H T$, Gileadean women, do not appear to be cyborgian at all. Though their bodies are systematically and legally violated by Gileadean men of the ruling class, Gileadean women do not undergo medical fertility treatments, genetic manipulation, or receive bionic prostheses. I have chosen Atwood's anti-science and anti-tech Gilead as my introduction to biopolitical cyborgs in order to highlight the ways biopolitical cyborganization operates as a disciplinary mechanism in the Foucauldian sense. Gilead is a state at war. Gilead maintains dual wars, both intrastate wars fought at its borders and internal wars fought against rebelling factions and subversive citizens. Gilead conscripts every citizen into these wars, positioning all citizens as either soldiers fighting for the cause(s) or traitors and enemies of the state. In addition to these interstate and civil wars, Gilead is also fighting a war against an unexplained infertility crisis. In its battle for the literal future of the nation, Gilead justifies a second conscription of all its citizens. For Gileadean women, the subjects of a patriarchal authoritarian state, soldierhood is hybridized with motherhood. Both assigned roles, the soldier and the mother, function as disciplinary mechanisms that normalize the individual. When hybridized, the result is a mother-soldier biopolitical cyborg whose individual agency is doubly bound by her mandated positions in biopolitical wars.

In 1984, a portentous year for an admirer of Orwell, Margaret Atwood picked up her pen and began crafting a story she had resisted writing for over a decade. The book she did not want to write, but felt must be written, was her own dark vision of a Western democracy's fall to an authoritarian regime. Orwell's influence is clear throughout the novel and Atwood pays homage 
through the use of Orwellian elements that have become hallmarks of the dystopian genre: constant surveillance; indoctrination programs; censored and propagandized media; perpetual war; state control of language; and a rigidly enforced caste system. ${ }^{15}$ The novel thus employs many of the generic markers of overt, militant state control that immediately signal its dystopian classification. Yet, Atwood's novel brings to the forefront mechanisms of control often glossed over or unrealized by her generic forefathers: gender, patriarchal misogyny, and motherhood. Situating her speculative nightmare more inline with Katharine Burdekin's Swastika Night, Atwood brings gender and sexism to the center of her critique through her vision of a statecontrolled reproductive program that equates women's citizenship with childbearing and motherhood.

Gilead, an authoritarian regime, has overtaken the former United States. To address the infertility crisis that threatens the survival of the population, Gilead enacts reproductive laws that promote the health of the collective body at the expense of individual rights and freedoms, and these laws are primarily imposed on the bodies of its female citizens. The state attempts to survive the crisis by forcing young, fertile women to become sexual surrogates and surrogate birthmothers, or "handmaids," for infertile couples of the ruling class. Though handmaids provide the most explicit example of Gilead's reduction of women to "two-legged wombs," all women in Gileadean society are hierarchically situated based on their fertility (136). Gilead's rhetoric justifies these impositions, as the fertility crisis is blamed on women's "sinful" use of birth control and abortion in "The Time Before." Babies act as currency in a fascist patriarchal

\footnotetext{
15 "Three things that had long been of interest to me came together during the writing of the book. The first was my interest in dystopian literature, an interest that began with my adolescent reading of Orwell's Nineteen Eighty-Four, Huxley's Brave New World and Bradbury's Fahrenheit 451, and continued through my period of graduate work at Harvard in the early 1960s. (Once you've been intrigued by a literary form, you always have a secret yen to write an example of it yourself.)" (Atwood "Haunted")
} 
system that outlaws the mention of male sterility, punishes female infertility, and rewards male fecundity with social and political advancement.

Atwood's handmaids are the quintessential example of the critical-dystopian mothersoldier. By foregoing science-fictional reproductive technologies and genetic engineering in her speculative vision of state-controlled reproduction, even shirking technologies already widely used in Western medicine, Atwood suggests that the probability of future state control of women's bodies has less to do with the potential of scientific developments to go awry than with the legacy of sexism and misogyny imbedded in Western patriarchal structures. As Atwood's constitutional democracy of "The Time Before" gives way to Gilead, long-held patriarchal precepts governing women's bodies and women's roles, repressed beneath a century of women's rights legal victories, resurface and are again rendered legitimate in the laws of the new regime. Though a nationwide infertility crisis acts as the impetus for state interference with its citizens' reproductive processes, Gilead draws on the US's legacy of sexism to justify enacting its biopolitical impositions on women's bodies. Through the narrator's frequent flashbacks to "The Time Before," Atwood correlates American female sexual and reproductive independence with Gileadean female subjugation, suggesting that the seeds of a Gileadean dystopia were planted long ago and only need the right political environment, rather than the right science, to take root. My analysis of $H T$ will begin with a look at American history's influence on Atwood's creation of the pre-Gileadean era, "The Time Before," specifically noting the culture's infatuation with what Lauren Berlant terms "Fetal Motherhood." Gilead's reproductive program builds on a history of gendered nationalistic rhetoric that conflates female citizenship with motherhood and privileges the future, fetal citizen over the mother. I will then turn to a discussion of the ways Gilead's ongoing civil wars against rebelling Christian factions, fueled by 
its metaphorical war against the infertility crisis, coerce citizen compliance with Gilead's reproductive program by positioning all citizens as soldiers battling to preserve the health of the body politic. I view Gilead's power matrix through the framework of Michel Foucault's theories of biopower to argue that the machinery maintaining Gileadean rule is the result of a calculated merger of disciplinary and regulatory/biopower technologies. Finally, I draw from Georgio Agamben's concepts of state-of-exception policies and "bare life"/"political existence" binaries to show how Gilead's perpetual creation of and war against Gileadean "others" unmasks tenuous boundaries between liberal-democratic government and authoritarian rule.

In many ways, Foucault, Agamben, and Atwood are telling a similar dystopian story. While Foucault and Agamben provide a conceptual framework and theoretical vocabulary for the matrixes of power governing modern states, Atwood makes biopolitical agendas personal through the story of her exemplary handmaid. While Foucault's model deftly explains the marriage between disciplinary technologies that target the individual body and biopower technologies that target the population, positioning the individual body and the body of the population as opposite poles between which norms traverse, his macro model doesn't allow for an in-depth look at the ways biopower technologies impede individual reproductive agency. Similarly, Agamben's work does much to explain how biopolitical programs make use of the homo sacer, but his framework, like Foucault's, does not focus on women specifically.

In the final analysis, the novel casts a pessimistic outlook of the US's ability to move beyond male/female hierarchies first established in patriarchal theocracies and then incorporated into secular humanism. Instead, against a backdrop of environmental and fertility crises and perpetual war, the novel forecasts the probability of patriarchal hierarchies to be codified in law and justified by the merger of motherhood and citizen-soldier. Gilead's perpetuation of civil war, 
as well as metaphorical wars against fertility and environmental crises, transforms its female citizens into soldiers, envisioning their bodies as battlegrounds in wars for the future of the nation. The novel warns that when bearing children becomes a woman's civic and soldierly duty, the state subjugates women to their unborn children in a gendered nationalism that values the idealized future citizens women may bear over their own individual and political worth.

\section{Fetal Motherhood in "The Time Before"}

"The deep foundation of the US-so went my thinking - was not the comparatively recent $18^{\text {th }}$-century Enlightenment structures of the republic, with their talk of equality and their separation of church and state, but the heavy-handed theocracy of $17^{\text {th }}$-century Puritan New England, with its marked bias against women, which would need only the opportunity of a period of social chaos to reassert itself. " - Margaret Atwood ${ }^{16}$

We experience the rise of Gilead through the first-person memories of an unnamed narrator whose disordered retellings jump without warning from her life in "The Time Before" to her experiences as "Offred," a Gileadean handmaid. Set in the United States circa 1990, Offred remembers "The Time Before" as a time of economic and sexual freedom for women, but also a time plagued by female sexual exploitation and an epidemic of male violence towards women and children that state authorities seemed inept to quell. In addition to skyrocketing infertility rates, kidnappings and the rates of birth defects were also on the rise, giving momentum to socially conservative rhetoric prophesying the end of US civilization and placing blame on women's rights movements. As the daughter of a feminist extremist, the narrator's memories of her early life are marked by her mother's activism, specifically her participation in pro-abortion rallies and book burnings of violent pornography.

While attending Harvard University, the narrator began an affair with a married man, Luke. The two conducted their affair in hotel rooms over the course of two years until Luke left

16 Atwood "Haunted." 
his first wife and married the narrator. ${ }^{17} \mathrm{~A}$ few years later, the narrator gives birth to a daughter. We experience the rise of Gilead through its devastation to the narrator's life and family. The tumultuous cultural and political environment, fueled by abortion debates and rising infertility rates, gave rise to the Sons of Jacob insurgency, which disguised their military coup as an Islamic extremist terrorist attack. After killing the president and most of congress in a one fell swoop, leaving a political vacuum, the Sons of Jacob instituted the Republic of Gilead, a fascist, theocratic police state modeled on an adulterated version of Biblical patriarchy. Overnight, women lost the legal right to hold property, and female employment and female literacy were deemed illegal.

As the US falls and Gilead rises, the narrator and Luke fear for their future since their daughter is the product of a now-illegal second marriage. The couple attempts an escape to Canada with their daughter. They are caught, Luke is shot, their daughter is taken, and the narrator is taken to the "Red Center" to be indoctrinated as a handmaid. The story we receive of Gilead is mediated through the narrator's experiences during her third assignment, as the handmaid "Offred" to Commander Fred and his wife, Serena Joy. Over the course of her assignment, the narrator is partially coerced, partially complicit in a budding affair with the Commander. Concurrently, Serena Joy, suspecting that her husband is infertile, goes outside the law in order to procure a much-coveted baby by setting up a clandestine sexual encounter between the narrator and the Commander's young Guardian, Nick. The narrator continues to routinely visit both Nick and the Commander without Serena Joy's knowledge or consent, placing everyone's lives at risk. The novel's climax occurs when Serena Joy approaches the narrator after discovering her affair with the Commander, and the subsequent arrest of the

17 Dunja Mohr has astutely pointed out the similarities between the narrator's meetings with the then-married Luke in "The Time Before" and her affair with the Commander. See: "Female Dystopia: Margaret Atwood's The Handmaid's Tale." Ahornblatter 8 (1995): 62-80 
narrator by Nick, who, while appearing to be an Eye (state spy), assures the narrator that he is in fact a member of Mayday, a female rescue group. The narrator's story ends ambiguously as the narrator steps into a van that will either take her to prison to await execution or on a journey towards freedom through the "Underground Femaleroad."

Though she began writing in 1984, Atwood's ideas for $H T$ first began to surface in the 1970s. She set a strict rule for her speculative world: "I would not include anything that human beings had not already done in some other place or time, or for which the technology did not already exist. I did not wish to be accused of dark, twisted inventions, or of misrepresenting the human potential for deplorable behaviour" ("Haunted"). Prior to writing, she began collecting stories of backlashes to feminist gains from around the world and compared these incidents to historical examples of female subjugation, taking particular note of the Iranian revolution and Ceausescu's implementation of strict reproductive laws in Romania. She also noted the concurrency of reports suggesting that fertility rates in the West were declining with the rise of neoliberal conservatism in the US and Britain (Neuman; Atwood "Haunted"). Then, in the early 1980s, Atwood moved to West Berlin beneath the shadow of the Berlin Wall. All around her, she saw ingredients for her dystopia.

Though Atwood chose to craft her social critique as a dystopia, $H T$ resonates with many themes about the relationship between reproductive autonomy and political agency explored in earlier print SF genres, particularly feminist science fiction. Following in the footsteps of Charlotte Perkins Gilman's 1915 Herland, and fictionally responding to Shulamith Firestone's 1970 call for women to "seize the means of reproduction," authors such as Joanna Russ, Suzy McKee Charnas, and Marge Piercy, created female-only or single gender societies in which 
women contested patriarchal subjugation by taking control of reproduction processes. ${ }^{18}$ Cyborg images in the era's feminist SF resonated with an emerging feminist movement that looked to technoscience to “manipulate [women's] very embodied relationship to sexed living-being itself. Not only was a feminist critique of science and technology declared imperative; technical practices themselves were possibly the means, the necessary tools, of feminism" (Murphy 5). To oversimplify, authors of print SF were using cyborg imagery to envision paths for individuals, particularly women, to use technoscience to negotiate for more control over their bodies and lives. Atwood's novel incorporates these ideas and places them within the contexts of rising social conservatism in the 1980s. Rather than imagining women seizing control of their reproduction by embracing technoscience, she engineers a world in which the state seizes reproductive control of its citizens, partly by denying women access to reproductive medicines and technologies. She thus subverts the eutopian hope of earlier feminist SF into a dystopian warning.

Atwood's idea of state-controlled reproduction preceded her selection of a setting. It was only after settling on Cambridge, Massachusetts, a landscape she was familiar with from her time as a graduate student at Harvard, that her authoritarian state's theocratic elements began to take shape. Believing that nations "never build apparently radical forms of government on foundations that aren't already there," Atwood heard echoes of Puritan ideology in Ronald Reagan's administration, which conflated free market capitalism, conservative Christianity, and "traditional family values" under the rubric of "Americanism." Atwood's piecemeal approach to her dystopian regime may have taken ideas from various historical systems, but, as the epigraph

18 See: Joanna Russ's The Female Man (1970); Suzy McKee Charnas's The Holdfast Chronicles (1974; 1978; 1994; 1999); and Marge Piercy's Woman on the Edge of Time (1976) 
to this section suggests, her novel leaves little doubt that the focus of her criticism is the legacy of patriarchal sexism embedded in US institutions and power systems (“Haunted").

Fueled by Jerry Falwell’s Moral Majority Lobby, which placed America’s future in its past by insisting that the road to social and economic progress ended in a nostalgic version of 1950s suburbia, remnants of Puritanical theocratic patriarchy echoed in Reagan's 1980 antiutopian presidential campaign. Morally, his campaign argued, America had made many wrong turns, but hope was not lost. His call, "Let's Make America Great Again," invoked voter participation with his plan to both free the market and return to "traditional American values." Atwood's Gilead presents an exaggerated version of the return-to-the-past that Reagan's campaign insisted upon. By choosing Puritanical New England, rather than the 1950s focal point of Reagan's nostalgia, Atwood is able to more clearly show how even what appears to be social progress is often shot through with, or even built upon, the social injustices of the past. Atwood's dystopia, which takes the future of the United States as its setting and subject, accepts the challenge of Reagan's slogan and delivers a vision of what the US would look like if its road back to the future, its return to "Again," passed through the 1950s and continued to its Puritanical origins. More pessimistically, Atwood's Gilead stands for the US as it always has been and reveals its centuries of social progress to be new coats of paint on an old house.

The first years of Reagan's presidency provided much fodder for Atwood's “The Time Before." As noted by Shirley Neuman, momentum for women's rights causes slowed during the 1980s, and many of the previous decades' gains were challenged and degraded during Reagan's administration (860). ${ }^{19}$ Neuman applauds Atwood's prescient fear that as "the world seemed to

\footnotetext{
19 In addition to wage gap increases and a decline in the number of females elected to political office: One-third of all federal budget cuts under Reagan's presidency came from programs that served mainly women, even though these programs represented only 10 per cent of the federal budget. The average amount a divorced man paid in child support fell 25 per cent. Murders related to sexual assault and domestic violence increased by 160 per
} 
be getting a little too free for women," the "fragility of newly acquired rights and equalities" would be met with a surge of violent opposition from many sides (860). Televangelists and conservative radio pundits encouraged women to leave the workplace and return to their "rightful" place in the home, citing spurious studies claiming that "single career women had high rates of neuroses and unhappiness" and virtually no chance of finding a husband after the age of thirty (861). Conservative media also propagated the fear of an impending US infertility crisis, insinuating birth control and abortion were to blame. While Rush Limbaugh was coining his "femi-Nazi" term, many other media outlets were declaring the beginning of a "post-feminist" era. Like Atwood's narrator, a growing number of young women in the early 1980s, who could attend college, buy birth control, and choose a safe, legal abortion, expressed mild apathy towards their mothers' feminist agendas and a belief that feminist activism was no longer needed. $^{20}$

Concurrently, pro-life and anti-drug campaigns busily amplified fetal motherhood iconography by propagating ultrasound images of in utero fetuses on bumper stickers, print ads, magazine covers, documentaries, billboards, and public service announcements about the risks of

cent while the overall murder rate declined; meanwhile the federal government defeated bills to fund shelters for battered women, stalled already approved funding, and in 1981 closed down the Office of Domestic Violence it had opened only two years earlier. Pro-natalists bombed and set fire to abortion clinics and harassed their staff and patients; Medicaid ceased to fund legal abortions, effectively eliminating freedom of choice for most teenage girls and poor women; several states passed laws restricting not only legal abortion but even the provision of information about abortion. The debate about freedom of choice for women flipped over into court rulings about the rights and freedom of the fetus. The Equal Rights Amendment died. (860)

20 The novel has faced some criticism its use of a postfeminist protagonist, as well as much attention, both positive and negative, regarding Atwood's censures of extreme feminist agendas (see: Sheckels; Neuman; Stillman, Peter, and Anne S. Johnson. "Identity, Complicity, and Resistance in The Handmaid's Tale." Utopian Studies 5.2 (1994): 70-86; Clarke, Elizabeth. "How Feminist Can a Handmaid Be: Margaret Atwood's The Handmaid's Tale." The Discerning Reader. Ed. David Barratt, Roger Pooley, and Leland Ryken. Grand Rapids, MI: Baker Books, 1995. 235-50). Atwood's approach to feminism, and the varied, "explosive" responses to feminist themes the book has received, places the novel within Ildney Cavalcanti's definition of feminist critical dystopias, which include: "three interrelated factors: the negative critique (of patriarchy as well as certain trends in feminist praxis and theory) brought into effect by the dystopian principle; the textual self-awareness in generic terms with regard to a utopian tradition and concerning its own narrative constructions of utopian 'elsewheres'; and 'in the nuclear sense of the critical mass required to make the necessary explosive reaction,' in the sense that the feminist dystopias may have a crucial effect in the formation and/or consolidation of a critical-feminist public readership" ("Utopias of/f Language in Contemporary Feminist Dystopias.” 48). 
using drugs and alcohol while pregnant. The message of these campaigns was clear: whether by engaging in risky behaviors while pregnant or by choosing abortion, mothers posed the highest risk to the future of the nation. Conservative campaigns made the most explicit use of fetal motherhood iconography; however, public discourse surrounding much of the decade's feminist platforms complemented fetal motherhood iconography's reduction of womanhood to childbearing and motherhood (Flavin; Berlant).

While equal pay, access to higher education, no-fault divorce laws, and mandatory child support were all embattled platforms of the era's women's movements, popular culture and the media often subsumed these issues under the more sensationalized debates surrounding women's reproductive freedoms. Particularly in the 1970s and 80s, the complexity of women's rights movements was often reduced to the "pro-life" vs. "pro-choice" dichotomy. Reducing women's movements, or feminist aims, to reproductive choice also promotes the conflation of womanhood with motherhood. Though their motivations were opposite of pro-life camps, many second-wave feminist platforms encouraged fetal motherhood metonymy by latching onto pro-choice rhetoric as shorthand for women's liberation ${ }^{21}$ (Flavin; Berlant).

The US's real-life 1980s sociopolitical conflicts between women and the state, pro-life and pro-choice activism, and progressive movements and their conservative backlashes, fictively play out in the narrator's flashbacks to Aunt Lydia's teachings as well as the Commander's explanations of the Sons of Jacob's doctrines. These scenes support Theodore F. Scheckles's analysis that the novel warns that, in the face of a population crisis, particularly declining birth

\footnotetext{
${ }^{21}$ Flavin notes the ways "the language of choice that has become so widely accepted fails to acknowledge that women's choices are often severely circumscribed by social and material conditions" (20). Specifically, poor women and women living in more rural, conservative areas often do not have the means or the transportation to "choose" abortion. Similarly, the SisterSong collective promotes "reproductive justice," a term coined in 1994 by the Women of African Descent for Reproductive Justice, a group of women who unified under the recognition "that the women's rights movement, led by and representing middle class and wealthy white women, could not defend the needs of women of color and other marginalized women and trans* people."
} 
rates, the historical tendency of feminist activism to focus on reproductive choice and sexual freedom provides an easy scapegoat for population control measures that violate women's bodies (88). Though the exact causes of Gilead's pre-revolution fertility crisis are unknown, and are most likely linked to environmental catastrophes and chemical warfare, feminist activism in "The Time Before" provides a vocabulary for reactionary backlashes to women's rights movements, which is then codified into Gileadean law after the revolution. In other words, the engineers of Gilead did not invent this metonymic reduction of women to "ambulatory chalices" (136); rather, they adapted this tactic from their "Time Before" enemies. Though used for contrasting ends, both feminist and neoconservative rhetoric prior to the Gileadean revolution reduced women's issues to reproduction and motherhood. Feminist campaigns centered around pro-choice advocacy while reactionary camps propagated fetal iconography. The combination of pro-life fetal iconography and pro-choice elisions of women's political agency to reproductive freedoms paved the way for a Gileadean policy that reduced women's civic functions to childbirth and motherhood.

During the narrator's re-education at the Red Center, Aunt Lydia, a middle-aged woman in charge of the center's indoctrination program, routinely blames pre-revolution feminism for the infertility crisis, and consequently Gilead's need of a handmaid program. Intentionally alluding to pro-abortion rhetoric, she deftly accuses feminist gains for Gilead's crisis: "We were a society dying, said Aunt Lydia, of too much choice" (25). Abortion is not the only choice Aunt Lydia, and the regime she represents, critiques. Pre-revolution, miscarriage rates skyrocketed and birth-defect rates had increased to affect one out of four live births. Conservative media blamed a triad of birth-control use, abortion, and advanced maternal age due to women placing careers before motherhood for these devastating trends. Aunt Lydia hints that instead of attempting to 
rectify the damage contraceptives and abortion had done to US birthrates, many pre-revolution women_-"lazy women"; "sluts"_ exacerbated the crisis by choosing medical sterilization in order to avoid miscarriage or giving birth to a special needs child (112).

According to Aunt Lydia, women who chose not to have children were neglecting their civic duty to help repair what feminists had done. The country was metaphorically at war with declining birth rates, and each woman of childbearing age had been conscripted to fight. Under Gileadean law, this soldier/deserter paradigm is intensified, as most sterile and post-menopausal pre-revolution women who advocated for women's reproductive choice are deemed "unwomen." Aunt Lydia often shows her handmaids-in-training "unwoman documentaries" of feminist protests in "The Time Before." Though she concedes that some feminist platforms must be condoned "even today," probably referring to protests against domestic violence against women, she refers to their pro-choice activism as "wasting their time... when they should have been doing something useful" (118). The message of the "unwoman" moniker is clear: the consequence for women's shirking of reproductive duties is the stripping of both their citizenship and their womanhood.

The Commander also blames feminism and its gains for Gilead's current population problems. Whereas Aunt Lydia focuses on pre-revolution women's neglect of motherhood and its consequences to the nation's birth rate, the Commander takes aim at women's sexual freedoms, blaming the dissolution of the "traditional family" for both the epidemic of violence towards women and the infertility crisis in "The Time Before." He claims that one consequence of women's sexual freedom was the common complaint among men to have lost the ability to feel. "Sex was too easy," the Commander claimed, resulting in men "turning off on sex, even...turning off on marriage" (210). In addition to yielding violent backlashes from men, the 
Commander correlates this male "turning off" with female lack of interest in childrearing. His slippery-slope logic argues that as women entered the workforce and gained legal rights, men's respect for their roles as mothers declined. As divorce rates and single-motherhood rates climbed, and women were forced to pay for the childcare services of a "brutal ignorant woman... out of their wretched little paychecks," women decided to "give up on the whole business" of motherhood (219). By his logic, Gilead's system of arranged marriages and handmaids "protects" women from pre-revolution brutalities. He believes, as is recited during Gileadean marriage ceremonies, Gileadean women will be "saved by childbearing" (221).

Gilead didn't need to invent a story to scapegoat women for Gilead's current fertility crisis; it only needed to appropriate pre-revolution pro-choice rhetoric in patriarchal terms. As Jenny Wolmark notes, Gilead not only co-opted second-wave feminism's focus on reproductive choice, but also its advocacy of a "women's culture and community" of collaboration (104). In a society that blames infertility on women's neglect of their civic duties to mother the future, the cure is "a spirit of camaraderie among women" all dutifully fighting for the collective cause. Aunt Lydia subverts the separatist feminist vision of women finding political power in femalecentric societies by using the image of a women's community as a coping mechanism for living under Gileadean rule. She imagines a future Gilead of women living harmoniously, "united for a common end" in which handmaids understood their position as "not a prison but a privilege" $(162 ; 8)$

The handmaid program is designed to diminish the handmaids' individuality by symbolically reducing them to their reproductive functions. The purpose of the handmaids' dehumanization is threefold: to make it easier for the Wives to accept the imposition to their homes and beds, to facilitate society's conceptual severance of handmaid services-egg donation 
and childbirth - from motherhood, and to reinforce the doctrine that the products of handmaid assignments, babies, benefit the collective social body. As summed by the servant Cora, "they're doing it for us all...or so they say" (10). Two rituals in particular exemplify the handmaids' reduction to "fetal motherhood" symbolization: the monthly impregnation "ceremony" and childbirth events.

The narrator's descriptions of the copulation ritual render it almost comically absurd. The household, including servants, gathers in the Wife's parlor as the Commander reads the story of Rachel and Leah from the Old Testament. After a moment of silent prayer for "success in all our ventures," the wife and handmaid retire to the wife's bed. The wife lies on her back and spreads her legs as the handmaid lies between her legs. The two women hold hands. Once the women are in position, the Commander enters, copulates with the handmaid, and leaves. All three remain almost fully clothed throughout the ritual. Post-coitus, the wife and handmaid are expected to lie still, reflecting and praying, for several minutes. Though the ritual is intended to enforce the symbolism of the handmaid as the wife's surrogate womb, Serena Joy's resentment and shame are palpable in the two ceremonies the narrator recounts.

The symbolic rituals surrounding handmaid childbirths are equally ridiculous. Births have become women's social events, attended by all handmaids and Wives in the community. The handmaid labors in the Wife's bedroom, coached by Aunts and supported by her fellow handmaids who collectively mimic her breath through contractions. When the baby begins to crown, the handmaid is led to a two-seated birthing stool. The laboring handmaid occupies the lower seat as the Wife is ushered into the room in "her ridiculous white cotton nightgown" and positions herself on the top seat. After the birth, if the baby is healthy (a "keeper," not a "shredder"), the wife is helped to her bed and is given the infant. The handmaid is pushed to the 
side and shielded by her fellow handmaids as the other Wives, full of wine and envy, enter to hear the blessed Wife name her new child.

Despite their absurdity, these two rituals reveal the horrifying degree to which Gilead has mobilized pre-revolution fetal motherhood iconography to strip its fertile female citizens of their reproductive agency and limit their sociopolitical value to their ability to birth future Gileadeans. In the next section, I will show how Gilead saturates discourse of reproduction in war rhetoric to further coerce compliance to its biopolitical agenda. Handmaids and Wives aren't just aiding the health and population of their society; they are soldiers courageously charging the front lines in battles against infertility, immorality, and incursion from rebelling factions.

\section{The Republic of Gilead: "Close your eyes and think of England"}

"How, when and why was it noticed or imagined that what is going on beneath and within power relations is a war? When, how and why did someone come up with the idea that it is a sort of uninterrupted battle that shapes peace, and that the civil order-its basis, its essence, its essential mechanisms - is actually an order of battle? Who came up with the idea that the civil order is an order of battle? Who saw war just beneath the surface of peace; who sought in the noise and confusion of war, in the mud of battles, the principle that allows us to understand order, the State, its institutions, and its history? "'-Michel Foucault, SMBD

Atwood and Foucault were thinking of and writing about power at the same time and shared cultural influences. Significantly, both were tuned in to the ways pervasive and ongoing war was used to shape and strengthen nation-states. While much $H T$ scholarship productively explores Gilead's disciplinary techniques using Foucauldian concepts, critical attention to the mechanisms of biopower at work in the novel has been largely neglected. In striking ways, $H T$ breathes life into Foucault's analysis of the merger of disciplinary power, biopower, and war expressed in Society Must Be Defended (SMBD). As SMBD postulates that permanent war undergirds the matrix of disciplinary and biopower technologies in the modern state, the lectures offer a useful vocabulary and framework for analyzing Gilead's complex, war-driven power system, augmenting previous scholarship focused on Foucault's thoughts on discipline. When 
read in the context of each other, $H T$ and $S M B D$ bring into sharp relief the tenuous border dividing liberal democracies and authoritarian regimes. While applying Foucault's concept of disciplinary tactics accounts for citizen compliance to Gilead's totalitarian rule, his concept of perpetual war as a justification for biopolitical sovereignty provides a more viable explanation for citizen conformity to Gilead's reproductive program.

As many scholars note, Gilead's power structure maps onto Foucault's delineations of disciplinary technologies and their resulting "docile," self-policing bodies presented in Discipline and Punish and History of Sexuality. Gilead's surveillance network, which uses both surveillance technologies and official state spies and also rewards for citizens who spy on each other, dramatizes Foucault's panopticon metaphor. Similarly, the primary purpose of all public institutions, such as "re-education centers," hospitals, and prisons, is to discipline Gileadean subjects via indoctrination and threats of physical harm. Further, Gilead forces citizens to participate in the punishments and executions of state enemies, implicating all citizens in Gileadean rule. Together, the Foucauldian-esque power structures Atwood envisions bring to life his arguments about the "interiority of power" in modern states, demonstrating "how power intrudes into and regulates society" (Sheckels 89, 81). ${ }^{22}$

The world the narrator enters after her time in the Red Center barely resembles the world she remembers. Society has been stratified into a rigid hierarchy in which castes are designated by their service to the state. Commanders hold the top seat of the male hierarchy, followed by "Eyes" (secret police), “Angels" (soldiers), and "Guardians" (police and personal assistants). Female ranks descend from "Wives" (of Commanders and high level soldiers), to "Aunts" (in charge of Gilead's female re-education programs), to "Econowives" (wives of low level

\footnotetext{
22 See Sheckel's for a synthesis of scholars who note the overlap between HT and Foucauldian concepts of power.
} 
soldiers), to "Marthas" (household servants), to "handmaids," "Jezabels" (prostitutes of a secret, state-run brothel), and finally "unwomen" (laborers assigned to work in "colonies"). Gileadeans are assigned uniforms indicating their status; for example, Wives wear blue, handmaids wear red, and Aunts wear brown. While Gilead's patriarchal structure affords men more social mobility than women, all citizens are heavily surveilled and controlled (Atwood "Haunted"; Michael 13840; Sheckels 80 ). Citizens' entire lives are determined by their social rank, including daily activities and authorized speech. For instance, when the narrator goes shopping for household groceries everyday with her assigned shopping mate, Ofglen, the two limit their greetings, conversation, and farewells to orthodox scripts learned at the Red Center.

Gilead governs all aspects of citizens' lives, from speech to sex. In addition to surveillance technologies, Gilead mobilizes a network of spies, or "Eyes," and Gileadeans conduct their daily lives with the understanding that anyone could be an Eye. In place of the US's legal doctrine of due process, Gilead arrests and holds citizens at will and converts universities into prisons where Angels torture prisoners and carry out public executions. Executions, termed "salvagings" and "particicutions," require the symbolic, and occasionally active, participation of the audience. Gilead impedes the development of friendships and alliances among its citizens by ritualizing all public gatherings. Gileadeans are only allowed to gather en masse for ceremonies and executions. All gatherings follow a strict script, and members of the crowd are given assigned roles. Further, Gileadeans must only speak to each other using memorized, sanctioned greetings and responses. Despite its Old Testament doctrines, Gilead does not have churches. Aside from births, there are no social gatherings among women, no places to talk and exchange information. The only breaks from quotidian life come in the form of public ceremonies and rituals: prayvaganzas (women gather to pray for fertility); group 
arranged marriage ceremonies; salvagings, or hangings, of criminals in which handmaids collectively pull the rope; and particicutions of accused rapists in which a mob of frenzied handmaids literally mauls the accused man to death.

As Sheckels correctly notes, Gilead's power system "mixes exchange and threat" (89). Both mechanisms allow Gilead to control social castes laterally. The pervasive threat mechanisms of "Eyes" and "true believers" constantly intimidate Gileadeans, reminding them of their powerlessness within the system. However, the genius of Gilead's power system is its incorporation of repression's corollary. In addition to threat power, Gilead also incorporates into the system space for power transactions between citizens. For example, though Commanders maintain the highest seat in Gilead's hierarchy, their Wives are granted power over the household, including power over the handmaids (136). The house thus became a site of contested power between Gilead's leaders and their legally dependent Wives. The combination of threat (of power) and exchange (of power) has developed a vibrant power economy that renders every moment of contact with another person a power transaction. The citizens of Gilead's lower echelons have very little "real power"; however, small amounts of power pass through each citizen, implicating all in Gilead's power economy (136). Though many scholars note Gilead's use of "salvagings" and "particicutions" to symbolize the handmaid's complicity in Gileadean rule, the narrator's story suggests that its incorporation of market principles just as effectively coerces Gileadeans' complacency and compliance. Further, the power economy allows even handmaids small amounts of agency over their own bodies. Handmaids routinely seek the help of younger men, such as doctors and Guardians, to conceive, knowing that giving birth to a live, healthy baby will safeguard them from ever being sent to the colonies as unwomen. Many have noted the narrator's small moments of agency in her dealings with the Commander, her affair 
with Nick, her interactions with other handmaids and her doctor, and finally, in her story-telling decisions to withhold information when recounting her experiences. ${ }^{23}$ The power economy explains how Gilead maintains order despite the lack of "true believers" presented in the novel. As the narrative progresses, even the most seemingly devout citizens-Serena Joy, the Commander, the Wives - are exposed as only playing their role in order to gain or maintain small increments of power within the system. In the end, the reader never encounters a "true believer" in Gilead, only well disciplined soldiers and mother-soldiers.

War dictates Gileadean life. Men's titles use military language, television broadcasts are saturated with war propaganda, and sanctioned conversation scripts between citizens begin with praises for Gilead's recent military victories. War is used as a justification for austerity measures and government rationings, and Wives spend their leisure time knitting scarves for soldiers and paying for prayer scripts for victory in wars against the rebels and infertility alike. Despite the permeation of war talk in Gileadean society, battles remain on the periphery. Gilead's war matrix closely follows Foucault's prescription. Gilead's outside enemies are reduced to their membership in enemy Christian factions - Catholic, Baptist, Quaker-and are most visible as televised images in propagandized news reports and as executed corpses, hanging from "The Wall" with faces covered and identified only by a sign indicating his rebel faction. Despite the saturation of war talk, these frontier wars have little impact on life in the "heart of Gilead...where the war cannot intrude except on television" (23). The more pressing fronts are those of the internal war between "true believers" and traitors and the metaphorical war waged

\footnotetext{
23 See: Mohr, Dunja. "Female Dystopia: Margaret Atwood's The Handmaid's Tale." Ahornblatter 8 (1995): 62-80; Stillman, Peter, and Anne S. Johnson. "Identity, Complicity, and Resistance in The Handmaid's Tale." Utopian Studies 5.2 (1994): 70-86.; and Baccolini, Raffaella. "Gender and Genre in the Feminist Critical Dystopias of Katharine Burdekin, Margaret Atwood, and Octavia Butler." Future Females, The Next Generation. Ed. Marleen S. Barr. Lanham, MD: Rowman and Littlefield, 2000. 13-34.
} 
against the infertility crisis. While Angels fight at the borders, all other castes fight Gilead's inner wars, dividing citizens into two groups: patriotic soldiers or dangerous traitors.

The metaphorical positioning of all Gileadeans as soldiers is made clear in Gilead's treatment of and rhetoric surrounding handmaids. All handmaids receive ankle tattoos with an identification number, which serves as a constant reminder to the narrator that she is "a natural resource" (65). Similarly, news coverage of women being smuggled out of Gilead via the underground femaleroad accuses an "espionage ring" of "smuggling precious natural resources over the border into Canada" (83). Guardians and Angels salute handmaids, like fellow soldiers, "because of the nature of our service" (21). Aunt Lydia takes a boot-camp approach to training young handmaids, suggesting her trainees "think of it as being in the army" and using military language to rally her troops: "you are the shock troops, you will march out in advance, into dangerous territory. The greater the risk the greater the glory" (113). The soldier metaphors surrounding reproduction extend beyond handmaids as well, as "abortionists" from "The Time Before" are rooted out and hanged as "war criminals" with "drawings of a human fetus" hanging from their necks, and the narrator comments on the Commander's lackluster performance during the monthly copulation ritual as "The commander... doing his duty" $(33 ; 32 ; 95)$.

As the narrator's story focuses on the plight of the handmaid, who, though despised, is still deemed a necessary and integral part of Gileadean society, her role still fits within Gilead's normalizing narrative. Despised though she may be, her society still values her role and considers her compliance essential to Gilead's eventual victory over declining birth rates. But murmurs of a different war seep from between the lines of the narrator's memories, exposing a rift between Gilead's stated goals and its hidden practices. As Sheckels notes, the infertility crisis underpins the logic for both the Sons of Jacob's insurgency and their design for Gileadean 
society (78). Babies in Gilead are a source of social and political currency. Wives and handmaids alike continuously refer to babies and children as "treasures," and the explicit goal of the Gileadean hierarchal structure is to increase the birthrate. However, fragments of a different story lurk in the narrator's allusions to and incomplete thoughts regarding unwomen, Jezebels, and the forced migration of various races. Agamben's biopolitical theories, which draw upon and adapt Foucault's superrace/subrace division, bring these politically ostracized groups to the forefront of Gilead's power structure, suggesting that it is the demarcation of "un"people that operates as the organizing principle of Gileadean rule.

Though Atwood's novel predates Agamben's work, his theories of how "bare life" and "political existence" shape state-of-exception suspensions of constitutional rights explain the effectiveness of the Sons of Jacob's insurgency. Agamben's Homo Sacer adapts Foucault's biopolitical superrace/subrace binary to a division between zoé or "bare life"-life reduced to biological functions - and bios or "political existence." Agamben uses homo sacer to resist Foucault's claim that analyses of power in modern states should move away from the juridicopolitical model of monarchial sovereignty. Instead, he argues that the continued practice of excluding individuals from law in modern states links systems of government that otherwise appear antithetical, such as monarchs and liberal democracies, authoritarian regimes and constitutional states. His linking of older state structures to modern democracies suggests the possibility of the liberal-democratic homo sacer to pave the way for democracies' devolution to authoritarian regimes. In Agamben's assessment, liberal-democratic concepts of "bare life" provide the basis for individual sovereign rights and rights to privacy. However, "The spaces, the liberties, and the rights won by individuals in their conflicts with central powers always simultaneously prepared a tacit but increasing inscription of individuals' lives within the state 
order, thus offering a new and more dreadful foundation for the very sovereign power from which they wanted to liberate themselves" (Homo 121). In other words, if the state can grant and protect individual sovereignty, it can also deny and revoke individual sovereignty.

Agamben fears that all that is required for the resurgence of sovereign rule is a state-ofexception threat to the democratic state, such as war, in which case the "'bare life' that in democracies results in the private having priority over the public" easily gives way to "a decisive political criterion for the suspension of individual rights" (Lemke 57). Using the metaphor of a concentration camp to represent "bare life," he warns, "the camp is the space that is opened when the state of exception becomes the rule" (168-9). Rather than equating democracy and totalitarianism as he is often accused, Agamben reveals the potential for totalitarian regimes to "radicalize biopolitical trends that... are already found in other political contexts and historical epochs and whose power today has increased rather than decreased" (Lemke 57). In Agamben's final analysis, historical movements and demands for states to recognize and legally protect individual rights to life and liberty may have strengthened the potential for authoritarian regimes to legitimize control of citizens' lives, liberty, and property (Lemke 56).

Atwood's Gileadean revolution seems particularly prescient in the shadows of 9/11 and the popularity of the Patriot Act in its immediate aftermath. To pave the way for the Republic of Gilead, the Sons of Jacob posed as "Islamic fanatics" and "shot the president and machinegunned the Congress" (174). The narrator's use of the pronoun "they" throughout her account of the time immediately following the coup reflects the confusion the country felt about this new enemy: "They blamed it on the Islamic fanatics, at the time"; "Keep calm, they said on television. Everything is under control"; "That was when they suspended the Constitution. They said it would be temporary"; “There wasn't even an enemy you could put your finger on" (emphasis 
added 174). What appeared to be the US Army stepped into the vacuum left by the coup that left the "entire government, gone like that" (174). The narrator remembers "there wasn't even any rioting in the streets" after the Army declared "a state of emergency" and instituted martial law (174). Though no one understood what was happening or who was to blame, the people valued the protection of the state over concerns of government overreach. Slowly, bit by bit and always under the guise of security, the insurgency took more and more:

Things continued in that state of suspended animation for weeks, although some things did happen. Newspapers were censored and some were closed down, for security reasons, they said. The roadblocks began to appear, and Identipasses. Everyone approved of that, since it was obvious you couldn't be too careful. They said that new elections would be held, but that it would take some time to prepare for them. The thing to do, they said, was to continue on as usual. (174)

The Sons of Jacob's early state-of-exception restrictions seemed to affect all citizens equally. Other phenomena that signaled the insurgency's larger plans were overlooked or misunderstood, such as the narrator's observance that "no children walked to school anymore, there had been too many disappearances" (175).

Although the narrator's friend, Moira, a feminist extremist, had warned the narrator on the day of the catastrophe to "Look out...here it comes...They've been building up to this," the narrator, like most Americans, did not sense the coming changes to women's positions. Unlike the Army's gradual restrictions of First-Amendment rights, its revocation of all women's rights and freedoms came, literally, overnight, alongside the revelation of the Sons of Jacob as the new Army. The narrator remembers the morning beginning "in the usual way," as she prepared breakfast for her family, drove her daughter to school, and then drove to her job at a small 
library. Prior to going to work, she visited a newsstand, the same one she visited nearly everyday, to purchase cigarettes. In the place of the usual woman working behind the counter was "a man, a young man, he couldn't have been more than twenty" (175). The young man is curt and cold to the narrator, telling her she can't purchase cigarettes because her "number's not valid" (175). Prior to the Gileadean revolution, the US had long ago ceased printing legal tender and had fully transitioned to electronic currency. Predicting something like debit cards, Atwood's US assigned each citizen a "Compucount" ID number that was electronically tied to his or her bank account, and funds were accessed through a matching "Compucard." Significantly, ID numbers included either an M or an F to indicate the citizen's sex. Though the narrator does not realize it at the time of her attempted cigarette purchase, overnight and without warning, the Sons of Jacob took over the US's electronic banking system, transferring all funds from "F" accounts to accounts of their husbands' or closest male relatives'.

Not long after the narrator begins her day at work, her male boss, who "looked as if he'd been drinking," turned off all the machines of female employees and announced, "I have to let you go. It's the law, I have to. I have to let you all go" (176). When the narrator demands to know why she is being fired, he reiterates, "not fired...Let go. You can't work here anymore, it's the law" (176). As the frantic narrator gathers her things, she realizes a new Army is there, enforcing the new law. She goes home and repeatedly tries to call her mother, who doesn't answer. Then she calls Moira, who comes over and explains the new world order. Within the span of twelve hours, all women were "let go" from their jobs and lost all access to money. On the same day, the Sons of Jacob implemented a new law denying women the right to own property (178). Though these changes shock the narrator, who initially cannot grasp the Sons of Jacob's motivation, Moira seems to have anticipated the possibility of such reversions to 
women's legal status and she is better able to process the insurgency's agenda: "They had to do it that way, the Compucounts and the jobs both at once. Can you picture the airports, otherwise? They don't want us going anywhere, you can bet on that" (179).

The narrator soon learns that Moira's predictions were correct, and she begins to hear rumors of women and "illegitimate" children disappearing. She still cannot locate her mother. She and Luke go to her mother's apartment and find that it has been ransacked. It appears that a violent struggle has taken place. Luke decides to take his family and run to Canada as it becomes increasingly clear that the new regime does not recognize second marriages. In hindsight, the narrator realizes that the regime was taking the children of "illegitimate" households and placing them with elite couples within the Sons of Jacob's ranks. The women who were disappearing were either being declared "unwomen" and shipped to "colonies" to work as agricultural workers, factory workers, and nuclear fallout clean-up crews, or detained in handmaid reeducation centers, all iterations of Agamben's concentration camps. As Moira later confirms, society at large had no knowledge or suspicion of the handmaid program until its full implementation (245).

The narrator and Luke are stopped before making it to Canada, presumably because someone who knew of their plans betrayed them. The narrator grabs her daughter and tries to run, hearing Luke being gunned down behind her. She and her daughter are captured and her daughter is taken. The narrator wakes up sometime later in the Rachel and Leah Re-education Center, or "Red Center." The narrator's story fails to fill in the next steps of the transition that secured the Sons of Jacob's insurgency as the new Gileadean law of the land. We are to assume these final stages occurred during her re-education at the Red Center. By the time the narrator reaches her third assignment, as the handmaid of Commander Fred and his wife Serena Joy, The 
Republic of Gilead reigns. Through clues in the narrator's reflections of her daughter's age, we can deduce that about three years have passed from her daughter's abduction to her assignment as Offred. She has yet to have a "successful" handmaid assignment.

The genius of the Sons of Jacob's insurrection was its guise as the United States Army and its promise to protect the country via state-of-exception suspensions of individual freedoms. Foreshadowing its eventual co-opting of feminist rhetoric, the insurgency first made use of institutional racism and sexism, the precursors of "bare life" and "political existence," already embedded in America's structures. Disguising their coup as an attack by Islamic extremists made use of a stigmatized and stereotyped enemy other already feared by the US social body. Similarly, the insurgency trusted men to react as Luke did to suddenly being entrusted with the lives and property of their wives, mothers, and sisters: to comfort and vow to protect.

When Luke returns home on the day the narrator loses her job and her money, he immediately embraces his wife and tries to soothe her by downplaying the significance of the new laws: "I'm sure it's temporary...It's only a job" (179). Rather than providing comfort, Luke's words signify his inability to empathize with the complex web of feelings and fears resulting from her sudden lack of political and economic agency. For the narrator, Luke's choice of words subtly aligns him with the Sons of Jacob's agenda by illuminating his incapacity to relate to her experience. The narrator's verbal and physical responses to Luke's attempts to assuage her make clear a new rupture in the foundation of their relationship. Though he still thinks of their marriage in terms of a partnership and views these new laws as affecting them as a unit, "We'll get through it," she distinguishes between her experience and his: "You don't know what it's like, I said. I feel as if somebody cut off my feet. I wasn't crying. Also, I couldn't put my arms around him" (emphasis mine 179). Luke and the narrator's responses to the day's 
events continue to conflict throughout the evening. His impulse to physically comfort his wife while verbally diminishing the significance of the laws is repeatedly met by the narrator's emotional and physical distancing from him as she interprets his attempts to comfort as revealing gestures indicating deep-seated desires for the economic and political power over his wife granted by the new laws:

"Hush, he said. He was still kneeling on the floor. You know I'll always take care of you.

I thought, Already he's starting to patronize me. Then I thought, Already you're starting to get paranoid. (179)...

Though Luke does not recognize it as such, his reaction to the narrator's new legal status supports the insurgency's agenda. Like Luke, rather than revolt beside the women they claim to love and respect, the men of the new world take seriously their new/old roles and vow to protect their new legal charges.

Gilead's treatment of racial others and women who refuse to comply with Gileadean dictates strips them of their political existence and reduces them to a state of "bare life." Resonating with Agamben's warning that state-of-exception threats provide justification for state radicalization of historical biopolitical trends, Gilead first excised itself of groups who won liberties and rights "in their conflicts with central powers" during the previous decades' civil and women's rights movements. HT has rightly been criticized for its dismissal of race, as the narrator's discussion of race is limited to an offhand reference to the "Resettlement of the Children of Ham" from the Detroit area to "National Homeland One," or North Dakota (83), and her memory of television footage of a cruiseliner filled with smiling and waving Jewish volunteer repatriation emigrants setting sail for Europe. The "Historical Notes" Epilogue reveals 
that "more than one boatload of Jews was simply dumped into the Atlantic, to maximize profits" (307).

Unlike its dismissal of race, the novel's connection of pre-revolution women's rights movements to Gilead's revocation of female sovereign rights is clear. The narrator's aside that "no one knows where old women go" (154) hints to the future of women who are no longer of use to Gilead's biopolitical agenda. We can surmise the fate of elderly Gileadean women by looking at the treatment of women during the revolution. Women who, pre-revolution, defied Gilead's definition of a "traditional family" — single mothers, wives of second marriages, feminists, lesbians, successful women in traditionally male careers_-faced one of three fates: reeducation as a handmaid, designation as an unwoman and a labor assignment in a nuclear waste colony, or a temporary assignment as a prostitute while young, followed by a labor assignment. While it initially appears that a woman's fertility was the deciding factor in where she was placed, the narrator learns later in the novel, when she is reunited with her friend, Moira, at Jezebels, that this was not always the case. Many of the women initially sent to the colonies, and all of the women assigned to Jezebels, have been sterilized. Despite Gilead's stated commitment to protect and increase women's fertility, which provides the justification for its oppressive hierarchy, it maintains systematic eugenics sterilization programs much like US programs that quietly operated behind the scenes throughout the twentieth century. Those who were unwilling or unable to comply with Gileadean regulatory norms were not only stripped of their political existence, but were also deemed a threat to the health of the social body and forcefully sterilized. Even in the context of a crippling infertility crisis, the Gileadean state divides its own into a superrace and a subrace, bios and zoé, for the biopolitical purpose of exterminating the threat of the latter to ensure the health and purity of the former. 
While Gilead maintains traditional wars with rebel factions and a metaphorical war against the infertility crisis, it is its underground civil war against the non-normative other that precipitates the Sons of Jacob insurgency and underpins Gilead's power structure. Though Foucault and Agamben's descriptions of biopolitical systems look more like the pre-revolution "Time Before" than Gilead, both warn that a Gileadean-esque future is a likely evolutionary development born of the nexus of disciplinary power and biopower power governing the modern state, enabled by the matrix of perpetual war justifying the state's "protection" of both individual lives and the health of the collective social body. Humanist demands that the state recognize, guarantee, and protect privacy and individual sovereignty unwittingly left a rubric in place for modern states to suspend these very rights and protections in the face of threats, whether real or fabricated.

\section{Conclusion}

Foucault and Agamben's work provides theoretical speculations of how liberal democracies might evolve, rather than devolve, to authoritarian regimes, just as $H T$ envisions Gilead growing out of "The Time Before." Biopolitical programs necessarily involve restrictions of individual reproductive agency in order to govern population rates. In their quest to govern "life in general," biopowers make use of long-standing social injustices to wage perpetual wars, boosting nationalistic loyalty to the state and justifying state encroachment into its citizens' personal lives. Foucault's insistence that biopower and disciplinary power operate simultaneously, complimented by Agamben's delineations of state-of-exception rhetoric giving rise to "bare life" enemies of the state, comes to life in Atwood's speculative nightmare.

Atwood's fictional handmaids, Jezebels, handmaids, Wives, and unwomen enliven biopolitical discourse by emphasizing that attempts to regulate life itself necessarily manifest as 
repressions to the individual reproductive body. Further, biopolitical systems that develop, or emerge, from patriarchal power structures will inequitably exercise biopolitical power on the bodies of its female citizens by reducing female civic worth to reproductive functions.

Biopolitical programs are necessarily nationalistic, as they bring individuals into a formation of a national, collective body, and as Anne McClintock asserts, "all nationalisms are gendered" (61). ${ }^{24}$ Neglecting to account for gender norms in analyses of biopolitical programs overlooks the history of nationalistic rhetoric used to mobilize motherhood as a civic and soldierly duty. $H T$ extrapolates this history and envisions a dark future in which such rhetoric gives way to the forceful control of women's reproductive bodies by the state. Biopolitical programs operate via the guise of securing the health and wellbeing of the population, but as the Commander tells the narrator, "You can't make an omelet without breaking eggs...We thought we could do better...Better never means better for everyone...It always means worse, for some" (211). For the women of Gilead, a life valued as a "two-legged womb" or an "empty chalice" is better for none (136).

Though Atwood leaves the narrator's future unclear, she provides an ending for Gilead in the "Historical Notes" epigraph. The epigraph appears in the form of a transcript of a key note address by Professor James Darcy Pieixoto at "The Twelfth Symposium on Gileadean Studies" held in Nunavut, Canada, in 2195. The Gileadean Age has long since come to an end, and we are led to believe a US-esque liberal democracy once again organizes North America. We find that the story we have just read was originally discovered as audio recordings on cassette tapes from

\footnotetext{
${ }^{24}$ According to McClintock, "male theorists have seldom felt moved to explore how nationalism is implicated in gender power" $(61 ; 62)$. Yet, evidence of nationalism's dependence on gender difference is evident in the nearuniversal iconography of the nation as a nuclear family unit. As the nation is the "homeland," its men are "fathers" and "founders," and its women are "mothers" who bear the nation's future male citizens/soldiers, "Nationalism is thus constituted from the very beginning as a gendered discourse, and cannot be understood without a theory of gender power" (63). Gendered national iconography simultaneously naturalizes the concepts of nation, gender, and family by providing the narratives of family and nation a "single genesis" (63). The symbol connotes unity and function within the complementary roles of a hierarchy, loyalty to kin and race, and shared legacy.
} 
the Gileadean period. Pieixoto admits to organizing the tapes as he saw fit and editing the "soidisant" manuscript. As many have noted, Piexoto's talk suggests that though "freedom" has been restored, sexism still underpins twenty-second-century sociopolitical structures. Prior to his lecture, Pieixoto makes an inappropriate joke about "enjoying" the "Arctic Char" the night before as well as the female "Arctic Chair" who just introduced him. After making another sexist pun regarding his choice to name the manuscript The Handmaid's "Tale," he repeatedly faults the narrator for spending too much time recording her feelings, missing her opportunity to record more details about the regime's power structure. Ironically, her "tale" encompasses discussions of many Gileadean power technologies; Pieixoto misses these critiques because the narrator mediates her discussion of power through its effects on her personal life. ${ }^{25}$

Pieixoto stresses in his talk that, though it is tempting to judge Gileadean society, "we must be cautious about passing moral judgment upon the Gileadeans": "Surely we have learned by now that such judgments are of necessity culture-specific. Also, Gileadean society was under a good deal of pressure, demographic and otherwise, and was subject to factors from which we ourselves are happily more free. Our job is not to censure but to understand" (302). However, the narrator's constant comparisons between "The Time Before" and Gilead suggest that Gilead partially results from an improper censure of the past by the social body of "The Time Before." Further, the implicit sexism permeating Pieixoto's speech hints that his current society has failed to adequately judge Gilead's sexist tenets and excise them from post-Gileadean systems (Sheckels 84). The society presented in the "Historical Notes" has softened and subsumed

\footnotetext{
25 See: Wesseling, Lisa and Jose VanDuck. "The issue of Responsibility in Margaret Atwood's The Handmaid's Tale." Against Patriarchal Thinking: Proceedings of the $6^{\text {th }}$ Symposium of the International Association of Women Philosophers. Ed. Maja Pellikaan-Engel. Amsterdam: VU UP, 1992, 243-51. See also: Raschke, Deborah. "Margaret Atwood's The Handmaid's Tale: False Borders and Subtle Subversions." Literature, Interpretation, Theory 6.3-4 (1995): 257-68. See also: Staels, Hilde. "Margaret Atwood's The Handmaid's Tale: Resistance through Narrating." English Studies 76.5 (1995); 455-67.
} 
sexism, masking it under a veil of liberal democracy. Atwood's final warning, then, is the dangers of a society that refuses to learn from its history, thereby reconstituting old injustices generation after generation, in power system after power system.

The "Historical Notes" epigraph also limits the eutopian power of $H T$ and challenges its categorization as a critical dystopia. ${ }^{26}$ Though Atwood leaves the fate of the novel's unnamed protagonist ambiguous, inviting the reader to imagine ways that she may have survived and possibly joined the Mayday resistance, Atwood's epigraph suggests that the eventual overturn of the Gileadean state could only manage to return society to the status quos of "The Time Before." In some ways, the "liberated" status of women in the $22^{\text {nd }}$-century is more ominous than the image of overt female oppression under Gileadean rule. The power structures governing Gilead are explicit and tangible. Gileadean women fully understand that their political worth and social value are determined by the future citizens they represent. Their status as "ambulatory chalices," like their roles as mother-soldier cyborgs in wars against otherness and infertility, is codified in Gileadean law and operates as the focal point of public gatherings, class stratifications, and reeducation curriculum.

Conversely, the "Arctic Chair" of the epigraph is bound by a less visible, insidious sexism. The epigraph features a community of academics who are blind to the systems of power governing their seemingly liberal society. Likewise, they are blind to their complicity in perpetuating the systematic oppression of women. In a twist of irony, Pieixoto notes: "As we know from the study of history, no new system can impose itself upon a previous one without incorporating many of the elements to be found in the latter... and Gilead was no exception to this rule" (305). His sexist puns and repeated denigration of the intelligence of the handmaid of

\footnotetext{
${ }^{26}$ As Sheckels notes, scholarship differs on the genre classification of $H T$. While some scholars read the novel as a feminist dystopia, others classify it as a critical dystopia; "the consensus is that Atwood pushes the dystopian genre in new directions" (footnote 1,77).
} 
his "Tale" suggest that he has not fully realized the implication of his statement. Just as the era of "The Time Before" could not fully excise its Puritanical roots, the bedrock of his "liberal" society is the humanist legacy of hierarchical dualisms. $H T$ 's final warning, then, is of the dangers of "colorblind" ideology, of a power system's ability to create illusions of liberation and equality while leaving systemic inequities intact. Following the mother-soldier images that dominate the handmaid's recounting, the epigraph leaves us with a different figure, one of an unwitting soldier faithfully fighting biopolitical wars that he has been disciplined not to see. 


\title{
Chapter 3
}

\section{Soldier-Cyborgs in Lois Lowry's 1993 The Giver}

\begin{abstract}
"To be One is to be autonomous, to be powerful, to be God; but to be One is to be an illusion, and so to be involved in a dialectic of apocalypse with the other. Yet to be other is to be multiple without clear boundary, frayed, insubstantial. One is too few, but two are too many.

High-tech culture challenges these dualisms in intriguing ways. It is not clear who makes and who is made in the relation between human and machine. It is not clear what is mind and what body in machines that resolve into coding practices. In so far as we know ourselves in both formal discourse (for example, biology) and in daily practice (for example, the homework economy in the integrated circuit), we find ourselves to be cyborgs, hybrids, mosaics, chimeras." -Donna Haraway, "A Cyborg Manifesto"
\end{abstract}

In The Handmaid's Tale, Atwood provides detailed explications of Gilead's biopolitical agenda as well as blueprints for The Sons of Jacob's oppressive tactics for coercing citizens' compliance to their regime. Her police state checks all of the boxes of conventional, fear-based dystopian governing systems, yet Atwood distinguishes her nightmarish hellscape by making clear the biopolitical impetus - a fertility crisis - for The Sons of Jacob's insurgency. The Handmaid's Tale thus explicitly links state governance of "life in general" to its inevitable conclusions: infringements to citizens' reproductive freedoms for "the good of the nation." Male leaders of the Gileadean State boast about their flagrant violations to women's bodies by invoking war rhetoric. Enemies, both human and environmental, besiege Gilead and all citizens are hybridized into citizen-soldiers. For women, the role of citizen undergoes a second hybridization, melding motherhood with civic responsibilities. Atwood's mother-soldiers thus demonstrate ways a state can wield cyborganization as a disciplinary mechanism.

Lois Lowry’s 1993 YA dystopia The Giver presents a considerably different version of a dystopian biopolitical state. The Giver opens in The Community, a faux-utopian society free of violence, pain, class divisions, fear, and hate. The absence of telltale, fear-based dystopian tropes masks the oppressive nature of the Community's governing system. By mastering control without fear, the Community perfects totalitarianism by disguising subjugation as comfort and security. In lieu of overt militant tyranny, the Community maintains homeostasis through their 
doctrine of Sameness, which includes technologically mastering the environment, governing birth and death rates, and genetically engineering its citizens. The only fears felt by members of the Community are fears of change and of shame (Latham "Discipline"; Latham "Childhood"). Though the Community's façade starkly contrasts the fear-based totalitarianism governing Atwood's Gilead, its governing system employs many of the same control tactics, particularly exercising its sovereign right to take life as well as maintaining a biopolitical program governing childbirth and reproduction. Whereas Gilead flaunts its power over its citizen's lives by dressing women according to their reproductive roles and by rendering childbirth and executions compulsory public events, Lowry's Community hides its processes of creating and taking life. In striking ways, the Community achieves a level of control Gilead strives for; homeostasis of the population and the environment is maintained and citizens comply willingly and without question with assigned roles. ${ }^{27}$

The Giver tells the coming-of-age story of twelve-year-old Jonas. As Jonas transitions from childhood to young-adulthood, he learns of the dark secrets that bedrock his seemingly perfect world and begins to recognize his complicity in maintaining the status quo. Critical analyses of The Giver, which tend to focus on Jonas's development, offer insightful commentary regarding the novel's importance to adolescent readers by highlighting Lowry's ability to

\footnotetext{
27 Since its publication, The Giver has received a mix of accolades and challenges. A recipient of the Newbery Medal in 1994, an ALA Notable Children's Book award, and an ALA Best Book for Young Adults award, The Giver has been incorporated into elementary and middle school curriculums nationwide. Despite its critical accolades, awards, and teacher endorsements, the book has maintained a high spot on the list of books most challenged by parents and banned by school districts. According to the American Library Association, The Giver maintained an average ranking of number 11 on the most challenged books list from 1990-1999, and moved to number 23 from 2000-2009: "Banned \& Challenged Books." www.ala.org. American Library Association, 19972012. Web.; For a concise summary of parental complaints see Baldassarro, R. Wolf. "Banned Books Awareness: The Giver by Lois Lowry." 27 March 2011.World.edu: Global Education Network. World.edu, 2012. Web.; For a full list of The Giver's awards and accolades see “The Giver"Teachers @ Random: Random House Teacher's Guides. Random House, Inc., 1995-2010. Web.
} 
connect growing up with accepting social responsibility and enacting political agency. ${ }^{28}$ These connections are valuable and work to justify the novel's importance as a YA bildungsroman; however, zooming out from a focus on Jonas's growth brings into view the biopolitical structures governing The Giver's Community and invites a reading of the novel as a critique of latetwentieth-century American politics, specifically the interplay between scientific developments and liberal democracy. My analysis brings into view the society's hidden use of advanced reproductive and genetic engineering technologies, technologies the state applies unilaterally to all citizens in order to homogenize the body politic. My vantage point foregrounds the cyborgian aspects of Lowry's Community and reveals its citizens to be re-imagined Huxleyan soldiercyborgs designed to comply with oppressive state agendas. By analyzing the complex disciplinary-biowpower matrix maintaining the Community's seemingly quaint tranquility, my

\footnotetext{
28 While this chapter will not explicitly discuss The Giver as an adolescent novel, various scholars, many of whom I will cite later in this chapter, have expertly explored themes in The Giver as they relate to adolescent readers and the young adult fiction genre. Many of these explorations focus on how psychosocial development is impacted by education, access to memory, forms of discipline, and pressures to conform to societal norms. See Carrie Hintz's analysis of how blending young adult fiction and dystopian genres also blends the development of self-identity with a political identity: "Monica Hughes, Lois Lowry, and Young Adult Dystopias." The Lion and the Unicorn 26.2 (2002): 254-64; See also Don Latham's claim that Lowry's adolescent protagonists' successful engagement with "adult" situations suggest that she questions the distinctions contemporary society draws between the two categories: "Childhood Under Siege: Lois Lowry's Number the Stars and The Giver." The Lion and the Unicorn 26.1 (2002): 1-15; Latham also explores how the novel works to introduce adolescent readers to societal power structures in "Discipline and Its Discontents: A Foucauldian Reading of The Giver." Children's Literature: Annual of The Modern Language Association Division on Children's Literature and The Children's Literature Association 32 (2004): 134-151; Daria Mazi-Leskover posits that the elements of fantasy in the novel encourage adolescent readers to explore conceptions of social ethics: "Power and Ethics in Lois Lowry's The Giver and Gathering Blue." Journal of Children's Literature Studies 2.3 (2005): 1-13; and Susan Louise Stewart highlights the narrative's attentiveness to pressures to conform to societal norms unique to adolescence: "A Return to Normal: Lois Lowry's The Giver." The Lion and the Unicorn 31.1 (2007): 21-35.
} 
analysis elucidates the novel's multiple warnings to a glossy, plugged-in American culture quick to forget its own history.

Critics of the novel routinely question the citizens' humanity. Carter Hanson points out that to American adolescent readers of the late twentieth and twenty-first century, the static society's perpetuation of peace and comfort appears "lifeless" and "robotic" (47). Likewise, Susan Louise Stewart describes the citizens as "drones" solely concerned with "maintaining the status quo" (28). Others point to the citizens' lack of personal choice and individualism as a challenge to their humanness (Lehman and Crook; Latham "Childhood"; Latham "Discipline"; Lea). Conventionally, such writers attribute the Community citizens' inhuman characteristics to their seeming inability to make subversive choices, and these scholars correctly identify many of the disciplinary structures at work in the Community that diminish the citizens' personal and political autonomy; however, thus far, critics have yet to offer a thorough analysis of technology's role in governing these seemingly inhuman subjects. Undoubtedly, Lowry’s lack of detail regarding the SF technologies at work in the Community dissuades such analyses. However, Lowry leaves breadcrumbs throughout the narrative that bring us close to the Community's technoscientific origin story. I gather the fragments of information that hint at how and why the Community founders, "back and back and back," turned to a cyborgian world. The fragmented tale that emerges is of a society, much like ours, that looks to technology to save itself from eminent environmental, social, and political destruction. I contend that the Community emerged from a biopolitical nation-state's implementation of a state-run biomedical reproductive program designed to maintain population rates, and that the state's choice to obscure details of this program from the citizens it produces underpins each of the "inhuman" characteristics discussed in Giver criticism. In Lowry's world, citizens' bioengineered, cyborgian 
natures render them blind to the mechanisms of power governing what they perceive to be personal choices, bringing them in line with Haraway's vision of men in space and Foucault's conceptions of the biopolitical natural body.

The Community's biopolitical success is rooted in its ability to separate its citizens from life processes and hide birth and death behind closed doors. Most citizens never witness a birth or a death. Biopolitical agendas require citizens to relinquish part or complete reproductive agency in order to maintain population rates in accordance with the collective body's needs. In designing Sameness, the founders of the Community understood the difficulty of achieving universal consent to population control measures if individual citizens understand the sacrifice of relinquishing control of one's own body. In essence, agency to use one's body at will is fundamental to the concept of choice. By denying its citizens knowledge of, and access to, birth and death, the Community denies its people the concepts of life and choice. While the citizens are no doubt cyborgian creations of a cyborgian world, their inability to value life, stemming from ignorance of birth and death rather than from genetic manipulation, is the ultimate challenge to their humanity.

Lowry's inclusion of genetic engineering and assisted reproductive technologies in her dystopian warning could be interpreted as what James Hughes terms a "bioLuddite" opposition to genetic engineering and biomedicine based on the fear that such technologies cannot be used safely and ethically, and will ultimately produce a posthuman that is inhuman. Such sentiments are captured in Stewart's conflation of genetic engineering with Sameness in her claim that "Jonas lives in a community set in the future, where science has finally reached its logical—and on one level, peaceful and perfect—conclusion...Science has erased difference" (23). While the Community does use genetic engineering to homogenize its citizens, I question Stewart's notion 
that Lowry presents homogenization as the logical conclusion of genetic engineering. Though this interpretation of Lowry's dystopia is seductive, Lowry avoids making a reactionary case that biotechnology will inevitably usher in the doom of humanity. While genetic science and biomedical tech play a part in the Community's structure, Sameness results from a communitywide ignorance of the ways genetic and reproductive technologies are used to structure their lives. Genetic engineering can just as easily be used to add diversity, just as reproductive technologies can, and often are, used to aid individual reproductive agency and ability.

Lowry avoids a bioLuddite argument for biotechnology's threat to humanity by omitting the degree to which the Community's citizens have been genetically altered. This omission suggests that humanness in a bioengineered world is determined less by artificial/natural binaries than by the cyborg's ability to value life and make choices. In the case of Lowry's soldiercyborgs, the ability to make self-beneficial choices is contingent upon democratic access to life processes and biotechnologies. Lowry's soldier-cyborgs are not genetically doomed to an automaton life. Despite Jonas's genetic design, he is able to develop an appreciation for life and choice as he gains knowledge about his cyborgian origins. Likewise, the novel's ambiguous ending allows for the possibility that the Community at large can move closer to Haraway's vision of ironic liberation.

Lowry's dystopian Community is the result of a society's undemocratic use of biotechnology to direct human evolution. As such, Lowry's social critique aligns with established attitudes within the SF community about the necessity of equal access to, and understanding of, high-tech developments. In Cyborg Citizen, for example, Chris Hables Gray asserts, "participatory evolution requires participatory government" (3). Participatory government in the age of the cyborg demands that citizens understand, interact with, and have 
equal access to the technologies shaping their lives. Gray sympathizes with the bioLuddite fears that genetic technologies cannot easily be separated from eugenic motives and that such technologies can too easily be wielded by the powerful few to control and oppress the majority. He stresses that science can be used either to save or destroy mankind, but rather than fear it, it is the responsibility of every citizen to understand it and work to create a society that ensures democratic access to life-enhancing technologies. Hughes makes a similar argument, warning that "becoming more than human can improve all our lives, but only new forms of transhuman citizenship and democracy will make us freer, more equal and more united" (xii).

Lowry's Community of seemingly inhuman cyborgs suffers from living in a technological world without an understanding of the ways technology has been used to diminish their ability to choose how to live their lives. Rather than using reproductive technologies to further individual reproductive freedoms, such technologies are used to divorce procreation from personal experience and parenthood. Similarly, rather than using genetic engineering to enhance capabilities for all, it is used to homogenize aesthetic features and inhibit senses. The Community does not need overtly oppressive coercion tactics to ensure compliance to biopolitical agendas as citizens' lack of understanding of their cyborgian natures renders them blind to the mechanisms of power governing what they perceive to be personal choices.

\section{Seeing Beyond Sameness}

The story opens as eleven-year-old Jonas "apprehensively" (4) awaits the Community's impending annual Ceremony. At the ceremony, Jonas, along with all of the other children born in the same year as Jonas, will be officially recognized as a Twelve (i.e., twelve years old) and appointed to a career assignment by the Committee of Elders. For the first third of the novel, 
readers follow Jonas as he performs his mundane, daily tasks while quietly anticipating the coming ceremony. Initially, Jonas and his world resonate with American iconography of the heteronormative suburban family. Jonas lives in a single-family home with a mother, father, and a little sister. He goes to school, does his homework, rides a bike, and spends a lot of time with his best friend Asher. However, we soon learn that these façades of familiarity mask uncanny differences. Jonas lives in a climate-controlled and moneyless world free of sickness, pain, social conflict, ego, vanity, and disrespect. Governed by the doctrine of "Sameness," the citizens of Jonas's world are motivated by interdependence, responsibility to the community, and the humiliation of standing out. Further, familial relationships are superficial. Jonas's parents are not biologically related to their children, and his family is the result of family-unit assignments made by the Committee of Elders. Jonas's parents, like all post-pubescent citizens, take pills to stifle sexual "stirrings" and deter emotional intimacy, and people do not touch each other. Though American audiences may find these cultural practices disturbing, Jonas accepts his community's functions as natural and comfortable; however, he too begins questioning the virtues of his community's way of life after receiving his career assignment.

At the Ceremony of Twelve, Jonas is selected to become the Community's most honored member, the new Receiver of Memory. The citizens of Lowry's world have no concept of history, geography, economy, religion, or personal property, and we soon learn that their ignorance stems from their inability to access collective, historical memories. Having decided generations "back and back and back" to eliminate pain, hunger, want, and war, the distant ancestors of the community decided to erase memory and history from all but one citizen, the Receiver, who must carry the burdens of yesterday for the community. Following the ceremony, Jonas is to immediately begin an apprenticeship with the current Receiver, who now calls 
himself the Giver. To receive memories, Jonas lies on his stomach as the Giver places his hands on Jonas's bare back. The memories of the community's past are then physically transmitted, one at a time, from the Giver to Jonas. The Giver can control the transmission process and carefully chooses the order and speed of memory transmission. Once a memory is transmitted, the Giver no longer has access to it. Though the novel does not offer a scientific explanation for how collective memories can be held by one person, the Giver is clear that Sameness depends on the role of the Receiver of Memory to function. If Jonas dies or leaves the geographical boundaries of Sameness before passing the memories he now holds to a new Receiver, the memories will automatically be released back into the Community and experienced by all.

Jonas is chosen to be the new Receiver because of his ability to "see beyond." "Seeing beyond" is ultimately a eutopian capacity to imagine a different way of life. Jonas's capability first manifests as an ability to see flickers of color. As Jonas receives new memories and, more importantly, learns to use these memories to decode the Community's power systems, he begins to understand that "seeing beyond" means having the ability to see beyond Sameness. In other words, Jonas has an innate ability to perceive the mechanisms of control governing the Community, and the Giver hones this ability by selecting which memories to transmit to Jonas.

As Jonas begins to receive memories of the past from the previous Receiver, he viscerally experiences intense physical pain, such as sunburns, starvation, and broken bones. He also experiences the emotional pains of envy and betrayal, and witnesses first-hand the horrors of war. But, he is also introduced to the intense pleasures of joy, emotional intimacy, sexual desire, and familial love. He develops a respect for nature and the environment by receiving memories of deep bonds between humans and animals. He begins to realize that his community-to which 
he no longer belongs - is made up of infantile adults incapable of seeing beyond the present moment.

Jonas's growing dissatisfaction with his seemingly perfect community culminates when the Giver decides to let him see a video recording of "Release," or euthanasia. The Community set-up hides death from its citizens by strictly controlling it. Medical developments have eradicated illness and disease, and accidental deaths are exceedingly rare. When adults grow too old to continue contributing to the community, they are moved to the "House of the Old" to "await Release." The Community has also used the euphemism of "Release" when referring to death for so long that the concept of death is no longer accessible to citizens. The Community holds "ceremonies of release" for the old, where citizens celebrate the life of a person and thank her for her service before she is escorted her through a door to "elsewhere." With the exception of the citizens whose career assignments include executing Release procedures, the community at large has no idea that Release means euthanasia. In addition to the elderly, the Community also systematically Releases "abnormal" newchildren, the smaller of two twins, and citizens who accrue three rule infractions.

Even after witnessing multiple deaths in the memories he has received from the Giver, Jonas still maintains a cognitive dissonance regarding Release. When the Giver allows Jonas to see a recording of a recent Release of a newchild, the truth of Release immediately ruptures Jonas's belief that the Community is, overall, a good place. This new knowledge ultimately inspires Jonas to leave the geographical borders of his community—with a newchild scheduled for Release in tow-knowing that his abdication will release the memories he now holds back into the Community for all to experience. Jonas and baby Gabe's journey to Elsewhere is treacherous, and the novel concludes with an image of Jonas and Gabe starving and freezing on a 
snow-covered hill. Jonas believes that he has finally reached the end of Sameness and will be able to safely deliver Gabe, via a red sled, to a life in Elsewhere; however, many readers interpret the ending scene as Jonas dying, and some believe Gabe dies long before Jonas ascends the snowy hill.

Lowry takes the meaning of utopia as "no place" to its extreme. The geographical setting is referred to simply as "the Community," and as a result of the Community's erasure of history and memory — and compounded by its complete technological mastery of the environment—it is not possible to determine the geographical positioning, and by extension the history, of Lowry's society. Jonas's Community is one in a network of communities within Sameness, but the novel gives little indication of the world outside of this protected network. The story opens in medias res, and because the decision to go to Sameness generations back is only vaguely described, the novel resists a chronological mapping of how—and why—this society came into being. In short, it is clear the novel is meant to critique something, but what that "something" is eludes simple identification.

Contributing to the various, and often antithetical, interpretations of Lowry's story and the cultural work it attempts are the story's multiple ambiguities, including the ending, and the novel's resistance to genre classification. The novel blends elements of fantasy, science fiction, the bildungsroman, young adult fiction, and dystopia while also significantly diverging from each genre's conventions. Although late-twentieth and twenty-first-century audiences agree that Lowry's invented society is intended to be dystopian, there is considerable critical disagreement as to whether the novel promotes anti-utopian or critical-dystopian sentiments. For example, The Giver shares eutopian elements with Thomas More's 1516 Utopia that, read within the socioeconomic and political context of the late twentieth century, gesture towards anti-utopian 
promotion of consumer capitalism and social conservatism (Stewart; Bradford et al.). However, Lowry's generic blending and ambiguous ending situates the work within the category of critical dystopia, offering a glimmer of hope for the protagonist's and, by extension, the reader's future. While I agree with certain points in the argument that it is anti-utopian, specifically that it relies on patriarchal tropes, the novel takes a critical-dystopian turn in its warnings to contemporary readers of the dangers of a society that masks, rather than addresses, social conflicts and injustices. Though it appears that the Community is predominantly egalitarian, there are subtle hints that certain career assignments, such as birthmother and laborer, have "little honor," suggesting a historical stratified caste system has been diluted, but not eradicated. Further, the Community's insistence on Sameness betrays an intense fear of otherness and difference. This is most clear in baby Gabe, whose inability to sleep through the night like other babies his age legally justifies his imminent Release.

The Community's fear of difference, combined with its use of genetic technologies to homogenize its citizens' physical features, evokes nineteenth- and twentieth-century eugenics practices as well as late-twentieth-century cultural debates about using genetic and assisted reproductive technologies to create "designer babies." Lowry wrote The Giver amidst a cultural shift from public fear of the "unnaturalness" of IVF procedures that characterized public opinion through the 1970 s and 80 s to public approval and the consequent skyrocketing of IVF rates in the 1990s. A growing number of groups opposed the high cost of IVF and feared corresponding developments in PGD. Theoretically, some warned, designer babies could amplify unjust social and economic hierarchies, since parents would be willing to pay exorbitant amounts to ensure their children a spot on the top of the socioeconomic ladder (Mundy; Henig). The Giver falls into this camp, as its technology-dependent Community isn't so much a warning that biomedicine 
will inevitably produce inhuman and unnatural people as it is a forecast that society will use technology to mask deep-seated, systemic injustices. Though the Community uses ATRs and genetic engineering to homogenize its citizens rather than to solidify a Huxleyean hierarchical caste system, the founders' impetus to institute Sameness emerged as a quick-fix solution to a stratified system that privileged certain types of bodies over others. Rather than working to create an egalitarian system that accommodated difference and individuality, the Community founders chose an ahistorical, colorblind stance in hopes of quelling its hierarchical tendencies.

\section{War and Life}

The memories Jonas receives depict a history not so different from the society that gives rise to Atwood's Sons of Jacob regime. These memories link the Community's doctrine of Sameness with the founders' biopolitical concerns with the health of the body politic in the face of war, overpopulation, and environmental degradation. The fragmented memories suggest that the cyborganized citizens' inabilities to access collective memory and see beyond Sameness function as disciplinary mechanisms working in the service of biopolitical concerns. As soldiercyborgs, the Community citizens' "natural bodies" are designed and disciplined to think and act in accordance with the Community's agenda (Foucault "Docile Bodies"). Don Latham has expertly traced the Foucauldian disciplinary mechanisms at work in the Community, claiming that the novel is primarily a story of power systems and the possibilities of social change through resistance, specifically resistance to assigned societal roles. Therefore, the novel acts as "a narrative embodiment of the social philosophy of Michel Foucault" (135). Latham's argument is compelling, as he identifies several Foucauldian disciplinary techniques at work in Lowry's Community that regulate, discipline, and subject its citizens, creating what Foucault terms 
"docile bodies." The Community's disciplinary techniques are complemented by what Foucault terms a "'culture of punishment' in which total control is achieved by a collective fear of retribution" (Latham 141). ${ }^{29}$ Though strict punishment in the Community is primarily an "invisible force," Latham argues that the fear of punishment thoroughly pervades the minds of the citizens, enforcing their self-policing habits. Visible punishment in the Community is limited to the use of a discipline wand on the hands of children and the elderly, and various types of public shaming, ranging from "silent chastisement" to public announcements, or "reminders," to correct one's behavior. Contrasting and underpinning the visible forms of public shaming routinely used in the Community is the invisible, mysterious punishment of "Release" (Latham 142). Three types of Release occur in the novel: the Release of the smallest of two identical twins; the Release of the Old; and the Release of citizens who have accumulated three rule transgressions. While Release of the Old is celebrated and Release of a Newchild is considered an unfortunate necessity, Release for rule transgression is considered the ultimate shaming, "an overwhelming statement of failure" (3). The citizens' differing reactions to types of Release stem from their ignorance that Release is a euphemism for both euthanasia and execution. Though they understand that Release is final, they do not understand that it means death. Most believe that Release is exile into Elsewhere, which is another concept they cannot understand as all histories of Elsewheres have been forgotten.

\footnotetext{
${ }^{29}$ Latham's list of disciplinary techniques includes: "spatial distribution of individuals" via assigned living and working quarters throughout a citizen's life; control of all schedules and activities, including sexual activities, privileging those that benefit the community rather than the development of the individual; "training in discrete segments," beginning with training in groups by age until age twelve, followed by training in segregated groups by career assignment; "the coordination of all parts such that the interests of the individual are subordinated to the good of the community," specifically through the Doctrine of Sameness's emphasis on blending in, politeness, and humility; constant surveillance via technology, encouraging citizens to surveil each other, and instilling self-policing habits from birth; mandating and ritualizing various types of confession; and finally, control of discourse by regulating language (136-41).
} 
Latham's thorough analysis of discipline and punishment convincingly explains how the Community has been able to maintain its level of control for generations with seemingly little resistance prior to Jonas's radical abdication of his assigned role; however, though it explains how the society maintains itself, it does not explain how it came to be, and why. Despite its totalitarian structure, the Community does not have a dictator or a tyrant. Even the Community Elders, who have great "honor," seem to have little power or control, as evidenced by longstanding jokes of their inability to change rules. Without access to memories or history, no one aside from the Giver, including the Elders, knows why the society is structured the way it is or how it came to be. In this sense, the Community embodies Fredric Jameson's vision of the postmodern "schizophrenic" society suffering from a "disappearance of a sense of history" and condemned to live in a depthless "perpetual present with which the various moments of his or her past have little connection and for which there is no conceivable future on the horizon" ("Postmodernism"). Jonas epitomizes this sentiment when, as the Giver begins to explain memories that go beyond first-generation memories, he responds, “'I'm sorry, sir. I don’t understand exactly. Maybe I'm not smart enough. I don't know what you mean when you say 'the whole world' or 'generations before him.' I thought there was only us. I thought there was only now"' (78). Aside from the Giver, no one in the Community has the capacity to understand the concepts of societal structure and design, much less the ability to envision change and enact revolution. The society, at present, is not the result of a maleficent, all-powerful regime, yet it maintains oppressive control over all citizens. Essentially, the Community is a totalitarian regime that no one rules.

Though the memories of origin have receded from collective memory, echoes of the past haunt the peripheries of Sameness and rupture its peace. In this section, I trace the historical 
fragments embedded in the Community's rituals and structures to argue that the original designers of Sameness were motivated by biopolitical ambitions to govern "life in general." Foucault insists that biopower and disciplinary power coincide and work together-biopower regulating the population and disciplinary power regulating individual subjects; my analysis of the biopolitical program underpinning the Community's practices complements Latham's assessment of its disciplinary techniques and moves toward an understanding of what a fully functioning Foucauldian disciplinary-biopower might look like. Further, a biopolitical assessment of the Community links the Community's disciplinary tactics with its program of state-controlled reproduction, suggesting that cyborganization in the Community functions as a disciplinary mechanism intended to regulate individuals within a biopolitical system. Finally, assembling the fragments of the Community's history reveals how the Community's biopolitical homeostasis depends on keeping birth and death processes hidden from citizens, resulting in a community of people who are incapable of valuing life's temporality.

After seeing the world of colors in the memories he receives, Jonas asks the Giver why anyone would ever choose to stop seeing color:

The Giver shrugged. "Our people made that choice, the choice to go to Sameness. Before my time, before the previous time, back and back and back. We relinquished color when we relinquished sunshine and did away with differences." He thought for a moment. "We gained control of many things. But we had to let go of others." (95)

Though the text does not specify the setting, fragments of memories transferred to Jonas, conversations with the Giver, and seemingly insignificant occurrences suggest that the answer to 
Jonas's question is that a history of war, racism, and overpopulation — a history much like that of late-twentieth-century America-motivated the Community's drastic turn to Sameness.

The most painful memories Jonas receives are of war and starvation, suggesting the world before Sameness was plagued by depleted natural resources, poverty, and acute overpopulation (Levy 51). After receiving a "torturous memory in which he had been neglected and unfed," Jonas asks the Giver why the Community's position of Receiver of Memory is necessary (110-11). The Giver explains that wisdom comes from the memories, and wisdom is needed to advise the Committee on possible changes to the Community's structure. The example the Giver offers makes clear the biopolitical motives driving Sameness. The Giver recounts a time when a number of citizens proposed increasing birth rates, allowing certain family units to receive an additional child, "so that the population would increase and there would be more laborers available" (111). The idea made sense to the Community of Elders, but they sought the advice of the Giver before proceeding with the change. The Giver drew from his memories and advised against the change, as "the strongest memory that came was hunger. It came from many generations back. Centuries back. The population had gotten so big that hunger was everywhere. Excruciating hunger and starvation. It was followed by warfare"” (111).

Foucault contends that perpetual war justifies and drives state governing of population rates, or "life in general," and that maintaining both inter- and intra-state wars continuously produces enemy "others," both within and outside of the state's borders (Society). Though the Community does not understand, and has no words for, war or racism, the hidden machinery operating its functions still depends on perpetual war and fear of the other. Despite the generations of Sameness — of comfort and population homeostasis — separating the time of these memories from Jonas's world, war continues to undergird the peace of the Community. The 
opening scene recounts a moment when Jonas feels "frightened... when an unidentified aircraft had overflown the community twice... he had seen the sleek jet, almost a blur at its high speed, go past, and a second later heard the blast of sound that followed." The "needle-nosed singlepilot jet" is unlike the cargo planes delivering supplies that he is accustomed to seeing, and its appearance startles the entire community and results in a command from the community-wide loudspeaker to seek shelter “"IMMEDIATELY ...LEAVE YOUR BICYCLES WHERE THEY ARE"” (2). The speaker soon reassures the citizens that the Pilot-in-Training is a member of the Community and has simply made a navigational mistake: “NEEDLESS TO SAY, HE WILL BE RELEASED'” (2). We find out later, as the Giver and Jonas discuss the event, that the Community was prepared to shoot the plane out of the sky, but the Giver advised them to wait (112). Though the community members know nothing of war, the presence of military-grade aircraft and the readiness of the community to shoot down unknown aircraft suggests the world beyond Sameness is a very different place and has the potential to violently threaten the Community's way of life. In essence, the Community that seems to have forgotten war maintains a military at the ready.

Though Community citizens cannot conceptualize an Elsewhere different from their society, or people with different appearances and cultures, nationalism, inseparable from racial and ethnic conflicts, still echoes in the Community's ritualized recitation of an anthem. Like war, the injustices of the Community's past society remain embedded in the Community's structures, resulting in citizens' absolute fear of difference, of the other, despite their perceived egalitarian philosophies (Latham "Childhood” 12). Though almost all citizens now have similar hair, skin, and eye coloring, their names suggest the Community was born of cultural, racial, and ethnic diversity: Jonas, Asher, Katya, Natasha, Yoshiko, Gabriel, Roberto, Bruno. As Stewart and 
Susan G. Lea both point out, the Community's move toward aesthetic homogeneity and literal colorblindness suggests a history, much like our own, of intense racial and ethnic unrest and systemic, institutionalized racism. Rather than redress injustices, the society opted for a "colorblind stance" with an emphasis on "Sameness and avoidance of difference, particularly at an individual level," that reflects a lack of "awareness of the institutional systems at work" (Lea 59). Stewart points to the citizens' light skin, Jonas and the Giver's clear (blue) eyes that allow them to "See Beyond," and the façade of nuclear family structures in her assessment that the society enforces rather than challenges the legacy of Western white patriarchy and its many injustices.

Indeed, the ideological biases, specifically gender hierarchies, of the Community's founders still shape the Community's aesthetics. The Community of Jonas's present is divided into heteronormative family units composed of a father figure, mother figure, and up to two child figures. Though gender does not come into play when the Committee of Elders determines a person's career assignment, and parenting roles within a family unit are not specified by gender, remnants of historical gender stratifications appear in the regulated hair and clothing styles of children: "females lost their braids at Ten, and males, too, relinquished their long childish hair and took on the more manly short style with exposed their ears" (46). In adulthood, the only remaining discernable difference between men and women occurs in the career assignment of "Birthmother." At the annual ceremony, a certain number of female Twelves are assigned the position of Birthmothers. Aside from Laborers, the role of Birthmother is the only position that the Community regards with mild contempt.

Hints of the Community's historical gender, race, and class hierarchies point to a biopolitical nation-state that, justified by perpetual war, devised a comprehensive population- 
control program, meticulously regulating both birth and death rates to protect and maintain the body politic. Because any means of external or systematic population control infringes on the individual right to choose when and how to reproduce, biopolitical policies invite resentment, rebellion, and revolt. However, Community citizens relinquish individual reproductive agency and natural death without reluctance. Through a combination of disciplinary techniques, reproductive technologies, and genetic engineering, the citizens of the Community thoughtlessly comply with the state's complete co-option of their rights to make life and die spontaneously.

Crucial to the Community's design is its ability to stifle the desire to create life and form family bonds. Though the nuclear family unit appears to be society's organizing principle, the nuclear structure is a hollow image. Family loyalty conventionally overshadows loyalty to one's state, so families pose a threat to the unity of the body politic. The Community averts this threat by separating parenting — both motherhood and fatherhood_-from procreation and replacing biological families with the state-issued "family units" that effectively resist citizens" conceptualizations of lineage and genealogy and enforce the development of residents' identities as citizens of the Community rather than members of a family.

The Community begins to craft citizens at birth by ordering each citizen's life according to a strict and ritualized procession of assignments. At the annual December Ceremony, all fifty children born to the Community during the previous year, referred to as "Ones," are assigned to a family unit. The Community assigns each Newchild a name, denying the new parental figures the ability to name the child in their care. Names are recycled through the Community, as each Newchild takes the name of a recently Released elder citizen. Throughout childhood and adolescence, citizens are grouped and organized according to age and career training. Upon entering adulthood, citizens may apply for a spouse. Upon approval, a man and woman are 
assigned a dwelling and, after further applications, may receive up to two children from the Community, one male and one female. Once a married couple's two children enter adulthood and are assigned dwellings of their own, the couple separates to live with the other Childless Adults, often never seeing his or her spouse or children again. When a Childless Adult is no longer able to fulfill his or her career assignment, he or she is moved to the House of the Old to await Release. Once Released, his or her name will be cycled back into the community at the next Ceremony of One.

Whereas the gendered implications of biopolitical programs are placed front and center in Atwood's dystopia, the differing effects of population control measures on women and men are more subtle in Lowry's Community. The novel makes no mention of biological fathers aside from an admission by the Giver that Rosemary, a previous Receiver-in-Training who chose Release after being unable to cope with bearing the memories, was his daughter. As the society has not yet developed Huxleyan artificial wombs, women's bodies are still needed to birth future citizens. To solve the biopolitical problem of women's desires to reproduce, the Community explicitly stigmatizes the career assignment of birthmother, birthmothers are separated from their biological children immediately after birth, and birthmothers are restricted from applying for a spouse or children.

At each annual ceremony, a few female Twelves receive the assignment of "Birthmother." In a society that supposedly honors and respects all citizens as valuable contributors to the Community, Jonas's mother is quick to tell Lily, Jonas's younger sister, that, “"there's very little honor in that Assignment”" (21). Birthmothers give birth three times in three years. After their duties as birthmothers are over, they are assigned as Laborers and work until they enter The House of the Old. Birthmothers are selected based on body type and intelligence, 
and are often considered lazy and pampered for the three years they are fed well and given rest $(21 ; 53)$. The stigma of Birthmother follows the woman throughout her life, as evidenced by a conversation Jonas has with an elderly woman, Larissa, during his volunteer hours at the House of the Old. As Jonas helps Larissa bathe, she recounts recent Release ceremonies, noting that the ceremony for Edna was "a little boring":

"Well, they tried to make her life sound meaningful. And of course," she added primly, “all lives are meaningful, I don't mean that they aren't. But Edna. My goodness. She was a Birthmother, and then she worked in Food Production for years, until she came here. She never even had a family unit. ...I don't think Edna was very smart." (31)

Whereas the role of motherhood is venerated and assigned, giving birth is denigrated, and reproductive processes are hidden. Community members have little to no knowledge of how citizens are created or what childbirth entails, and they lack the capacity to consider the emotional and physical consequences of a birthmother's duties. Since we are not given access to the thoughts and feelings of a birthmother in the novel, it is impossible to surmise whether the process is traumatizing to the birthmother, or if the medications all citizens take to repress sexual "Stirrings" also suppress birthmother-child bonding. ${ }^{30}$ What is evident in the novel's references to birthmothers is that the Community founders feared the birthmother-child relationship to the point that they took extreme measures to prevent its occurrence.

As readers learn, the Community founders feared for the existence of their war-ridden, hopelessly stratified society and devised a plan to guarantee the survival of their lineage. They began with the problem of population control. The body politic was exceeding the limits of its

30 While the Community's reproductive practices remain hidden in The Giver, the fourth and final novel in the series, Son (2013), tells the story of Gabe's mother and her struggles letting go of her baby and acclimating to life as a laborer. 
natural resources; however, state regulation of its citizens' reproduction is inherently tricky business. The founders created a blueprint for guaranteeing citizens' universal compliance to population control measures: separate procreation from the roles of parenthood; reduce loyalty to one's family by conceptualizing "family" as a temporary assignment to a "unit"; keep family iconography intact while inhibiting intimacy; make childbirth and death invisible to the community at large; and erase collective memories. The result is a citizenry incapable of developing transgenerational considerations, such as legacy and lineage. In eliminating the concept of futurity, the founders of the Community discovered the linchpin to unchallenged state governance of life itself. Put simply, the members of the Community literally have no idea what has been taken from them.

\section{Cyborgian Citizens of a Cyborgian World}

Like most mechanisms of control organizing and maintaining the Community's society, technology is not a focal point in the narrative; however, "understated high technology is implied" throughout the novel (Levy 51). What appears at first to be a quaint, low-tech, utilitarian commune of tunic-clad bicyclers is slowly revealed to be a society dependent on and surrounded by SF technologies. While Lowry never provides an explanation or explicit description of the Community's technological developments, we can piece together a general idea of technology's role through the fragments of memories Jonas receives. The topography has been leveled, the climate is controlled, and there is no sun, rain, or snow. There are no seasons and there are no animals, only fish raised in a hatchery. The Community of Jonas and the Giver's present was at one time precisely designed and constructed by melding artificial with biological, but the processes involved have been lost along the way. Either the Giver does not know, or 
chooses not to disclose, the degree to which the Community citizens and the world they inhabit are both biological and machine.

Lowry's Community gives narrative breath to Donna Haraway's vision of a cyborgian earth in which the boundaries separating the technological from the organic are indistinguishable (“Cyborgs and Symbionts" xii; xiii). Jonas and Gabe's journey to Elsewhere takes weeks. As they travel away from their Community, little by little the borders of Sameness begin to overlap with the borders of Elsewhere. It begins as a curve in the road, then the foliage begins to change, and then they hear birds. Soon they feel sunshine. The weather gradually begins to cool. Eventually, they encounter snow, which seems to mark the end of Sameness and the edge of Elsewhere. There is no dome or wall separating climate-controlled and sunless Sameness from Elsewhere. There is no discernable barrier preventing the birds Jonas and Gabe encounter from venturing into Sameness. Technology and earth appear to work seamlessly together. Rather than challenging boundaries separating nature and machine, Lowry's Community dissolves boundaries all together. Haraway extends the term "cyborg" to include the planet itself, describing a cyborg earth as "the natural habitat, and the launching pad, of other cyborgs" (xiii). Similarly, Gray defines the cyborg as "a self-regulating organism that combines the natural and artificial together in one system" (Cyborg Citizen 2). Gray’s definition does not limit cyborgian status to humans, but includes any "organism/system that mixes the evolved with the made, the living and the inanimate" (2). Lowry's Community of colorblind soldier-cyborgs reflects both Haraway's and Gray's concepts; the citizens are both the creators and products of their cyborgian earth.

Just as Lowry dissolves boundaries between Sameness and Elsewhere, she also refuses to make clear the degree to which the Community's citizens have been cyborgianized. We know 
citizens are conceived through either IVF or artificial insemination, but the omission of which procedure is used makes determining biological maternity impossible, since IVF procedures can include donor eggs as well as donor sperm. Aside from the Giver's claim to be the father of Rosemary, there is also no discussion of or allusion to biological fathers or sperm donors. We know that genetic engineering is a central concern of Community scientists because the Giver jokes that Jonas's friend Fiona's hair, which is red, "must drive them crazy" (94-5), but there is no indication of whether or not genetic engineering is used solely for aesthetic characteristics or if other characteristics have been enhanced or inhibited. We know that the Community's medical technology has advanced to the point that pain, sickness, and disease have been eradicated, and all post-pubescent citizens take pills to suppress strong emotions and sexual desires. We know that all citizens are colorblind, but, since Jonas and the Giver are capable of regaining the ability to see color, we do not know if the citizens' colorblindness is the result of genetic engineering, a medical intervention, or a complicated interplay between the citizens' bodies and their cyborgian environment. ${ }^{31}$ In other words, though we learn that the Community does have color, it is unclear whether or not the citizens' colorblindness is contingent upon remaining within Sameness's geographical borders. Similarly, the science behind the role of the Receiver of Memory is never explained, an omission that some scholars claim marks the moment the novel moves from SF to fantasy (Levy 53; Hanson 46). The lack of details surrounding the Community's environmental, biomedical, and reproductive processes is further compounded by the Giver's frequent

\footnotetext{
31 The Community's control of language, including the founders' choices to restrict the Community's vocabulary and insist on "precision of language," undoubtedly contributes to the citizens' inabilities to conceptualize history, futurity, elsewhere, death, and intimacy (ex. Jonas doesn't know the words "grandparents" or "love" until he receives them from transmitted memories). It is possible, then, that the Community's colorblindness, at least in part, results from the loss of the words for colors. Jonas, however, receives flickers of the color red prior to receiving any memories of, thus knowing the word for, red.
} 
description of features of Sameness, such as colorblindness, as being "choices" made "back and back and back," suggesting will and desire, at least initially, contributed to the cyborgian present.

Though Jonas and his community seem to embody the borderless melding of nature and culture characteristic of Haraway's ironic cyborg, Lowry's citizens are not fully capable of realizing their potential to use their cyborgian makeup to further individual liberation, to enhance human capability, to become more human. Community citizens' cyborg qualities render them less able to think, feel, and see, and even more reliant on and loyal to cultural norms, which leads to readers' common perceptions of Community members as less than fully human. Since Lowry's cyborgs do not feel love, do not understand life and death, are incapable of developing deep bonds with others, and cannot see color, they seem to fit within Brian Stableford's definition of the "adaptive cyborg," or "people redesigned to operate in an alien environment, sometimes so completely that their humanity becomes problematic" (290). Since we do not know the degree to which man and machine have mixed to produce Lowry's cyborgs, we are primarily left to question their humanity based on their nonphysical characteristics, specifically their emotional and intellectual capacities.

The first suggestions that the citizens of the Community may be something other than human come with Jonas's first received memories. In essence, we begin to question the Community's humanity as Jonas begins to question his own. Prior to receiving memories, Jonas has no concept of "human," as the only living beings he's ever seen are fellow citizens and fish. As he gains memories, he begins to consider the changes from "back and back and back" to Sameness to be losses. As these losses accumulate - color, grandparents, birthdays, hills, snow, sunshine - he begins to develop a concept of inherent rights and their connection to desire. These conceptual developments are most evident in his ruminations on color. After his first memory of 
color, and the Giver's explanation that the people "chose" to relinquish color, Jonas "fiercely" bursts, “'We shouldn't have!'” (95). After receiving colorful memories, Jonas becomes impatient with his inability to see colors consistently. The Giver attempts to assuage Jonas by insisting that Jonas will develop the ability to see color in time. Jonas, again, responds emotionally:

“But I want them!” Jonas said angrily. "It isn't fair that nothing has color!"

"Not fair?” The Giver looked at Jonas curiously. "Explain what you mean."

"Well..."Jonas had to stop and think it through. "If everything's the same, then there aren't any choices! I want to wake up in the morning and decide things! A blue tunic, or a red one?"

He looked down at himself, at the colorless fabric of his clothing. "But it's all the same, always." (97)

Though Jonas doesn't have the vocabulary to describe his feelings accurately, he is beginning to consider the ability to see color as a right that has been taken from him. As his emotional capacity begins to deepen with each new memory, he develops similar desires and feelings of loss for other experiences relinquished to Sameness.

Lowry often uses the emotions of animals in Jonas's received memories to draw deep contrasts between the people of Jonas's world and our conceptions of humanity. In the first instance, Lowry uses a memory of a mourning elephant to introduce Jonas to the emotion of grief. The memory begins in a "completely alien" hot and dry landscape and with the "sharp crack of weapons" (100). Jonas sees men with both dark brown skin and light skin and remembers the Giver's explanation that " there had been a time when flesh had different colors"” 
(100). The men are crowded over a large elephant, cutting the tusks, and Jonas sees the blood of an elephant on the ground. The sight gives Jonas "a new perception of the color he knew as red" (100). As the men leave, Jonas sees a second elephant come out of hiding and drag branches over to the mutilated elephant to cover the missing tusks. After covering his companion, the elephant "tilted its massive head, raised its trunk, and roared into the empty landscape. Jonas had never heard such a sound. It was a sound of rage and grief and it seemed never to end" (101). The sound haunts Jonas long after receiving the memory. Though he does not yet understand death, he is beginning to understand mourning. Just as the memories of the elephants teach Jonas grief, memories of humans bonding with other animals, such as horses and dogs, teach him concepts of companionship. As with the absence of colors, Jonas begins to consider the absence of animals to be a loss and a violation.

It is tempting to read the cyborgian elements of Jonas and his Community as a warning against technology_-specifically reproductive and genetic technologies that alter the processes of making life. Such a reading would position The Giver as a fictional precursor to Francis Fukuyama's 2002 Our Posthuman Future. Fukuyama, who defines human nature as "the sum of the behavior and characteristics that are typical of the human species, arising from genetic rather than environmental factors," supports biomedical advances that cure diseases, but not those that “enhance" genetic traits (130). While he glosses the potential for enhancing technologies to widen and solidify socioeconomic divisions, his primary warning is that we will enhance ourselves to the degree that we are no longer biologically human. He fears that a truly posthuman future poses potential threats to liberal-democratic principals based on natural human rights. At first glance it appears Lowry has created such a world. Biomedicine, reproductive technologies, and genetic engineering have aided in the production of a colorblind, asexual, and emotionally 
inhibited population devoid of biological family ties. Though law and order are thoroughly understood and enforced, citizens seem to have no concept of individual, inherent rights to their own bodies, minds, and life processes. Technology undoubtedly plays a role in the citizens' abilities and capacities, but Lowry allows Jonas — and the Giver before him, and the Receiver before, etc.- - to grow beyond artificial and cultural developmental inhibitors to move towards becoming an active, thinking, deciding, and autonomous person. Lowry complicates a Fukuyama-esque biological reading of human capacities - i.e., genetic essentialism—by obscuring the boundaries between choice and genetics and linking choice to wisdom from the past and knowledge of the present. Jonas doesn't move towards autonomy by becoming more genetically human, or less cyborgian, but rather by coming to understand how he and his community came to be.

Significantly, Lowry associates an individual's ability to make self-beneficial and autonomous choice with her or his knowledge of birth and death processes. Jonas never receives a memory of pregnancy or childbirth, though, like all citizens, he is vaguely aware of the birthmother career assignment. There is no primal scene and no mythic origin story. In the Freudian sense, citizens' are denied a formative trauma significant to the child's psychosexual development, a denial that contributes to the citizens' overall arrested development. I suspect that the founders' intentions for concealing the Community's reproductive processes are two fold: to completely sever familial ties from biology, and to circumvent the "man in space's" apocalyptic return to dust — a fate that the Giver's memories suggest the society was rushing towards - by denying citizens' the ability to imagine an edenic origin story. Whatever the founders' intentions may have been, their insistence on the omissions of both a primal scene and a birth scene allows the Community to perfect a form of control Atwood's Gilead strives for. 
Whereas Gilead showcases the mechanics of reproduction by way of public and semi-private mandated rituals, rituals that inspire resentment to Gileadean rule, the Community dissuades organized resistance to its sovereign rule by masking all associations between reproductive processes and personal/political power. For my argument, the omission of this detail has two consequences. First, the omission helps Lowry avoid making a completely biological argument for why the Community appears less free than contemporary American society. In other words, the omission resists what may be a readership's tendency to point to a specific practice, such as IVF or surrogacy, as the culprit. Second, because Jonas never receives a memory of pregnancy or childbirth, he is not able to fully shift from the "man in space" or "natural body" pole to an ironic liberation by the story's end. He maintains elements of both.

Though Jonas is never given a memory of birth, he receives many memories of death. His first real understanding of death comes from a memory of war, when, as his memory-self is dying in a battlefield, a fellow soldier, after asking Jonas for water, dies: "his head fell back, his lower jaw dropping as if he had been surprised by something. A dull blankness slid slowly across his eyes. He was silent" (119). Jonas recognizes the elephant's blank expression in the dead soldier's eyes and is overwhelmed as he scours the battlefield and sees countless dying bodies of men and horses. Though he doesn't yet have the vocabulary to describe his feelings, his actions suggest the memory has taught him what dying means and, with it, to value life. Days after Jonas receives the memory of war, he sees his friends playing "attack-counterattack" in a field, wielding imaginary guns and shooting each other (133). The children fall to the ground when "shot." Though he used to play the game often, Jonas now understands that the game simulates war. The children ask Jonas to play and pretend to shoot him. Jonas reacts viscerally, shuddering and trying not to cry. He tries to explain that the game is cruel and begs them not to play 
anymore, but he quickly gives up his attempts to explain war to those who have no concept of death or pain. His visceral response evidences his coming awareness that life is precious because of its finititude.

Throughout the process of receiving memories, Jonas waffles over whether the Community was right to give up difference and choice in order to move to Sameness. Initially, he seems to mourn the loss of color and sunshine, but agrees that the world before was " "not safe"" since people left to make their own choices, such as choosing spouses and careers, could “choose wrong"” (98). He also enjoys memories of family gatherings that include multiple generations, but acknowledges that the Community's segregation of citizens by age is much more "practical"” and "“organized" (124-6). As he receives more memories of pain, hunger, and death, his attention, and rage, turns towards his role as a scapegoat. At first he resents the unfairness of his burden, feeling the pain would be easier to handle if memories were evenly distributed, but as he gains wisdom and develops emotions, the burden of physical pain gives way to the weight of loneliness and isolation. He can no longer talk to his friends and family unit as he used to and sorrows for their lack of knowledge and feeling. He grows to love them, though they do not have the capacity to requite.

Jonas gradually moves towards the belief that the Community should break away from Sameness, yet his ultimate epiphany comes only after witnessing Release. Though the memories have taught him about death, he remained ignorant of Release, holding onto the belief that Release means exile or transfer to Elsewhere. He has long known that Release is a part of his father's duties as a Nurturer of Newchildren. Newchildren who are not developing on schedule are routinely Released, as are the smaller of two identical twins. Jonas's father is charged with the Release of an identical twin during the story, and that afternoon Jonas chats absentmindedly 
about it with the Giver. The Giver solemnly mutters, "I wish they wouldn't do that"” (146). Jonas, thinking only that "He liked the thought of seeing his father perform the ceremony, and making the little twin clean and comfy. His father was such a gentle man," expresses his wish that he could watch his father Release a newchild. The Giver explains that he can, because all Releases are recorded, and immediately orders a receptionist to play the recording on his video screen.

Jonas excitedly watches his father weigh both twins, hand off the bigger of the two, and sweetly talk to and play with the smaller of the two as he prepares him for Release. Jonas chatters excitedly, narrating what he's seeing, until the Giver commands that he be quiet and “"Watch!" His father gently and methodically injects a needle into the newchild's forehead, soothes the now crying and squirming infant, and waits as the poison takes effect. Jonas still does not understand and patiently waits for his father to comfort the child and perform a ceremony:

As he continued to watch, the newchild, no longer crying, moved his arms and legs in a jerking motion. Then he went limp. His head fell to the side, his eyes half open. Then he was still.

With an odd, shocked feeling, Jonas recognized the gestures and posture and expression. They were familiar. He had seen them before. But he couldn't remember where. (150)

As Jonas struggles to conjure the memory, he watches his father begin to tidy the room, until:

Once again, as he had on the playing field, he felt the choking sensation. Once again he saw the face of the light-haired, bloodied soldier as life left his eyes. The memory came back. 
He killed it! My father killed it! Jonas said to himself, stunned at what he was realizing. He continued to stare at the screen numbly. (150)

In disbelief, Jonas watches his father place the newchild in a small box and drop him down a garbage chute. As the truth of Release sets in, "Jonas felt a ripping sensation inside himself, the feeling of terrible pain clawing its way forward to emerge in a cry" (151).

Understanding Release dismantles Jonas's belief in the goodness of his Community. He immediately despises and fears his father, and worries for his friends who have been assigned nurturers of newchildren and caregivers of the old, since he now knows they will be trained to kill. Jonas descends into an inconsolable fit of fury and fear as the Giver tries to explain, "Listen to me, Jonas. They can't help it. They know nothing" (153). Jonas's final revelation is that the Community hasn't just been denied choice, deep feelings, and aesthetic pleasures, but the very capacity to comprehend and appreciate life. This incapacity is not the result of genetic engineering or reproductive technologies, but a consequence of being separated from birth and death processes. The Community's acceptance of Release stems from a lack of understanding of, rather than a disregard for, life.

Throughout the course of the story, Jonas's family unit has been caring for a newchild, Gabriel, who has been struggling to sleep through the night. Missing this developmental milestone typically results in Release, but a temporary exception has been made to give Gabe more time. Despite his extra year of care, Gabe continues to have trouble sleeping at night. One night over dinner, shortly after Jonas gains an understanding of Release, his father nonchalantly announces that the decision has been made to Release Gabe the next morning. Jonas has grown to love Gabe and chooses to escape in the night with the child and leave Sameness. The journey takes weeks and is rife with danger, and Jonas and Gabe suffer from dehydration and starvation. 
We are left with an image of Jonas and Gabe, starving and freezing, on the top of what seems to be the same snow-covered hill, holding the strings of the same red sled, from the first memory Jonas received from the Giver. Whether Jonas is dying or he is about to sled through the edge of Sameness as he believes, he knows that the memories he holds will be released back into his Community, forcing all citizens to confront the structures supporting and dictating their lives.

\section{The Choice to Choose}

While many scholars praise Lowry's work for championing the importance of individual freedom, the novel has also faced criticism for its emphasis on choice, since the concept of choice in American society is often associated with individualism and consumer capitalism. Such critiques tend to identify the communal structure of the Community and the citizens' fear of "standing out" or "being different" as the target of Lowry's critique. In essence, scholars who would classify the novel as anti-utopian feel that the novel promotes the fear that any move toward socialism will be a move toward a dystopia (Stewart; Bradford et al.). Such critiques suggest the novel encourages us to “critique Jonas's culture and not our own” (Stewart 33). Stewart, in particular, focuses on choice in her criticism of the novel as a promotion of neoliberal and patriarchal ideologies, arguing, "what appears to be a radical approach to adolescent literature actually reinforces cultural norms. In short, the text represents a return to normal" (23). In her view, Jonas's actions may seem radical, but American readers accept his rebellion because it may return his Community to a society that looks more like present-day America. She rightly critiques the novel's presentation of two male figures, the Giver and Jonas, "both of whom have light skin and pale eyes" as being superior to, and determining the fate of, the "remainder of the dark-eyed, light-skinned community... of drones who seem to have no desires except to maintain 
the status quo" (28). She then crafts a compelling argument that, despite the novel's insistence on the importance of individual choice, Jonas's actions result in a "fundamentally ironic and deconstructable moment" (24). In Stewart's view, American readers champion Jonas's assertion of agency and choice when he abdicates his duties as Receiver of Memory. However, the audience does not perceive that by leaving, Jonas denies the Community the ability to remain in Sameness. Jonas, not the Community, decides to rupture Sameness by releasing the memories he holds back into the Community. According to Stewart, his decision presents an all-too-familiar scene of one powerful white man making a decision that determines the social structures of his society $(24) .{ }^{32}$

In essence, Stewart criticizes Jonas's decision to deny the Community the choice to choose choice. Though I agree with many of Stewart's claims, I question her assumption that the Community would have been able to make such a choice if Jonas had offered it to them. Without memories and access to life processes, the Community is essentially unable to make choices. Jonas's departure is necessary for the Community to evaluate their society and decide whether or not to maintain Sameness. In other words, Jonas's Community did not choose Sameness - the Community's founders "back and back and back" made that decision. Jonas's departure doesn't ensure a return to modern-day American "normal" as Stewart suggests; it only ensures that the Community will now be aware of the costs of Sameness, as well as the costs of a departure from Sameness's comforts. In essence, Jonas's departure opens the door to a future ironic liberation for Community citizens. Prior to Jonas's departure, there is little hope for Community citizens to

\footnotetext{
32 Stewart convincingly argues that the third novel in the series, Messenger (2004), justifies her categorization of The Giver as an anti-utopia as it tells the story of Jonas's fate, thereby denying the reader the choice of imagining the ending. The extratextual details of Jonas and Gabe, she argues, negate the ambiguity of The Giver's conclusion. While valid, the story of what happens to the Community after Jonas departs, what choices they make, are not disclosed further in the series. The only clue given is that the Community decides to send all of its books, originally housed in the Giver's dwelling, to Jonas.
} 
begin to shift from "men in space" to an "ironic liberation." While Jonas's departure certainly doesn't guarantee that the Community will be able to make such a transition, it allows for the possibility. More importantly, it allows for readers to imagine such a possibility.

Jonas chooses to walk away, abandoning his "father" and moving closer to Haraway's ironic cyborg vision. As he gains knowledge and emotional depth, he does not lose his cyborgian qualities. He learns to feel, reason, and choose despite his genetic design and technologically determined environment. Lowry thus suggests that the potential of cyborganization to liberate or enslave hinges on the cyborg's knowledge of how she came to be. Like Haraway's “illegitimate offspring" image, cyborg-Jonas has the potential to revolutionize his world, a potential that can only be realized by embracing, understanding, and wielding his cyborgian qualities against his intended design. He was designed and created to be a scapegoat, to hold the memories of the past for his community. Jonas ultimately forsakes his designed purpose, realizing that it may cost him his life, and embraces his potential to break down the boundaries separating Sameness from Elsewhere. To be clear, Jonas's rebellion doesn't fully transition him to a position of ironic liberation. He still doesn't fully understand how he came to be and he still displays dualistic tendencies in his acceptance that he only has two options - comply or walk away. He is still very much alone and only beginning to desire connections with others. However, Jonas's departure incites a revolution by forcing the Community to reckon with its design. Though he may not fully recognize all available options for systemic change, his subversive action opens the door for others to work towards a more eutopian posthuman future.

Lowry's community of cyborgs thinks they have choice, just as they think they understand their world. As the Giver notes, they are very well trained and educated; yet, "“they know nothing"' (105). Despite his strange world, Jonas is a relatable character from page one. 
He initially seems to be very much like his American adolescent readers. As we follow Jonas's many awakenings, each one slowly revealing his cyborgian world to us, we are left to ponder how much of the machinery governing our own world is lost on us. Are we the well-trained, well-educated, and well-designed citizens of a planned liberal democracy, eliding choice with consumerism and individualism and unable to envision structural change? Are we inhibited by our design or by the lost memories of how we came to be? Are our "choices" simply veiled mechanisms of Sameness, steadily maintaining the status quo? Written for adolescents coming of age in a posthuman, war-ridden world, the novel asks readers to contemplate their own cyborgian natures and consider the possibility that they are the colorblind soldier-cyborgs of a fully realized, colorful dystopia.

\section{Conclusion}

Jonas and his Community are the products of a precisely planned biopolitical program that incorporates cyborganization as a disciplinary mechanism. Cyborganization does not receive the full blame for the Community's lifeless and robotic appearance; rather, the state's melding of artificial and natural is just one of several disciplinary tactics used to regulate individuals as well as the body politic. Lowry's soldier-cyborgs bring to life the full extension of Foucault's "natural body" metaphor. Community citizens believe that they are capable of making autonomous choices, but they have been preprogrammed, through a combination of biotech cyborganization and other disciplinary tactics, to make choices in accordance with their state's biopolitical agenda. The Community's governing system achieves the ultimate goal of conventional dystopian states: complete, unchallenged rule. In fact, the system is so perfectly designed that it 
now regulates and controls itself. Aside from the Giver, no one understands how the system works or why it's in place.

Despite the dystopian realities of Jonas and his fellow soldier-cyborgs, Lowry infuses her cyborg protagonist with eutopian potential. Though the biopolitical world Jonas inhabits uses cyborganization to keep citizens in line, Jonas finds ways to challenge his designed compliance. The story of Jonas is the story of a soldier-cyborg coming to understand his hybrid nature and laying claim to his humanity by making choices that counter his Community's mandates. In Lowry's formulation of humanity, in which humanity is aligned with the ability to imagine future generations and make self-beneficial and subversive choices, Jonas must first understand his cyborganization before he can become fully human. Haraway's ironic cyborg exposes the oppressive, dualistic nature of edenic origin stories and points to the liberating potential of unholy and unnatural couplings. Lowry's Community also makes a statement about origin stories, specifically about the oppressive potential of removing them completely. Jonas and his Community do not need to have an edenic origin myth restored, but their potential ironic liberation depends on an understanding of the mechanisms of power controlling their choices, including biomedical cyborganization. Jonas begins to realize his humanity in the moments when he also begins to understand his hybridity. As a soldier-cyborg metaphor, Jonas embodies the confluence of power structures that work to discipline and control us all, and his coming of age tale invites us to examine the hybrid disciplinary mechanisms at work in our own conceptions of self and choice. 


\section{Chapter 4}

Bare-life-cyborgs in Paolo Bacigalupi’s 2009 The Windup Girl

"In my view, ethical posthumanism needs to move away from this subject of humanness; the 'post' of posthumanism should not be a post-biological embodiment. The 'post' of posthumanism should be a 'post' to the heritage of humanism, which makes humans the only subjects in a world of objects. An ethical posthumanism must work against this boundary of the human from the nonhuman, refusing this final ground of abjection. An ethical posthumanism which acknowledges that self is materially connected to the rest of the world, in affinity with its other subjects, is an accountable posthumanism. It is a posthumanism that can embrace multiplicity and partial perspectives, a posthumanism that is not threatened by its others." -Sherryl Vint, Bodies of Tomorrow

Lois Lowry's The Giver speculates a dystopia arising from well-intentioned desires to use biotechnology as a solution to longstanding systemic injustices. Conversely, Paolo Bacigalupi's The Windup Girl imagines a world in which nation-states and mega corporations implement posthuman programs that intentionally exploit legacies of State Racism and patriarchal sexism in their creation of human/nonhuman cyborgs. Drawing from Georgio Agamben's work, I term biopolitical cyborgs whose transgeneic bodies place them outside the legal protections of human rights laws, such as Bacigalupi’s New People, "bare-life-cyborgs.” Whereas soldier-cyborgs forecast dystopian results of submerging the artificial beneath the flesh, masking the political functions of cyborganization, figures of bare-life-cyborgs connect cultural impulses to clearly demarcate the nonhuman components of posthumans to humanist legacies of binary othering and the biopolitical necessity of State Racism. Emiko, The Windup Girl's eponymous posthuman, exemplifies both of these connections. As a transgenic posthuman, she occupies her biopolitical and biocapitalist society's lowest subrace status, is legally vulnerable to enslavement, and can be killed with impunity. As a female posthuman created by patriarchal and capitalistic "gods," she is designed to fulfill heteronormative masculine fantasies of ideal femininity and female sexuality. Emiko's posthuman body, which renders her more subjected to gender hierarchies and State Racism than her non-modified women peers, predicts dark ends to the potent confluence of neoliberal and biopolitical motives propelling today’s biotech and biomedical industries. 
In The Windup Girl, calories have become currency in a future world controlled by agribiotech corporations and ravaged by generipped seed stock and transgenic animals. In his renderings of patented, sterile seed stock and fertile transgenic creatures, Bacigalupi comments on several threads of dialogue surrounding today's biotech advancements. His calorie companies critique current laws and practices that allow corporations, driven by short-term goals of bottom line profits and quarterly reports, to bring the world's food supply under the purview of intellectual property rights. He thus speculates that apocalyptic potentials are embedded within legal protections of neoliberal biocapitalist markets. Similarly, his vision of New People foretells the potential of liberal democracies to enslave genetically modified persons without violating laws designed to protect the inherent rights of natural humans. New People consequently represent a designed class of what Georgio Agamben terms zoe or "bare life" beings who, though living, fall outside state legal protections. Further, his exemplary windup, Emiko, gives life to feminist work exposing the echoes of humanism that often lurk behind posthumanist enthusiasm.

Like mother-soldier and soldier-cyborg metaphors, bare-life-cyborg figures align humanity, or being human, with political agency and personal choice. Emiko's humanity is dually challenged by her illegal status and her genetically engineered impulses to submit and serve powerful men. Resonating with The Giver, Bacigalupi's dystopia steers clear of a judgment against biotechnology and instead sets its critical sights on modern-day social injustices and inequitable legal and economic structures that have the potential to be exacerbated by the genetic modification of life. Also like Lowry, Bacigalupi ultimately carves a space for eutopian hope amidst a world of dystopia through his protagonist's epiphanic transformation. However, diverging from Lowry's soldier-cyborg Jonas, who must recognize and overcome his inhumanity in order to become fully human, Bacigalupi's bare-life-cyborg Emiko must learn to embrace and 
wield her nonhuman characteristics in order to enact her humanity. In the process, she becomes what the non-modified superrace fears: she becomes a threat to the health of the human body politic while also demonstrating that she is better equipped to survive on the planet that her human creators have destroyed. Specifically, this figure warns against opening up biomedical and genetic technologies to free-market trade in patriarchal and capitalistic societies. In effect, she portends the extinction of humanity and a new era of the posthuman.

\section{A Generipped Dystopia}

I want to begin with a thorough summary of the novel in part because scholarship tends to avoid the work of summarizing a novel as complex and unwieldy as The Windup Girl. Though the bulk of my analysis will focus on Emiko, the novel's larger story arc and Emiko's interactions with the other four protagonists clarify the biopolitical and bioeconomic functions of generipping in Bacigalupi's world. For example, her subordinate position to Hock Seng, a Maylan refugee stranded in a city that is openly hostile to foreigners, underscores the legal stratifications separating bare-life humans and bare-life-cyborgs. Further, as a bare-life-cyborg figure, Emiko evidences the inextricability of biopolitics from bioeconomics, and reveals how hierarchal gender and race binaries are bound up in both. Emiko is the product of a biotech corporation that designs their transgenic commodities to sell for the highest price. Designed to appeal to the most powerful consumers of patriarchal capitalism—wealthy men-Emiko's creators exploit gender norms by engineering feminine, subservient women.

Set in $23^{\text {rd }}$-century Thailand, The Windup Girl depicts a world plagued by famine, disease, and environmental destruction wrought by global warming and the domination of the world's food supply by Midwest "calorie companies." Calorie companies "generip," or 
genetically modify, and then patent "genehacked" sterile seed stock, and they have monopolized the world's food supply for two centuries. As if the manipulation and patenting of virtually all plant life isn't bad enough, Bacigalupi extends his dystopian speculations of patenting life to the creation and marketing of transgenic animals and human/nonhuman beings. Private and government generippers in various countries have created and patented chimeras intended for both amusement and labor, such as Cheshire cats and Megodonts. Like genehacked seeds, transgenic animals often yield unforeseen consequences to both ecosystems and global markets. The Cheshires were created as novelty entertainment for a child's Alice in Wonderland themed birthday party; however, their abilities to disguise themselves, hunt, and reproduce has led to the extinction of domestic cats as well as many bird species. Megodonts, massive elephant-like animals used to generate power for factories, dirigible airships, and high-rise buildings, require professional human handlers who have unionized and now influence global markets through a system of extortion and bribes. And in Japan, where the labor force has been stricken by declining birth rates, generippers create "New People" or "windups," genetically modified and lab-born transgentic human-nonhuman genehacks designed to serve. New People are given increased longevity and superhuman physical abilities, but, because generippers "learned too much from cheshires," New People are denied reproductive organs (114). New People's sterility acts as a governor, assuaging human fears that New People could thrive following the extinction of non-enhanced humanity.

To ensure that the lives of New People remain in service to their creators and owners, their life and death processes are determined by their owners' whims and demands. When a windup has "fulfilled her duty," she is "compassionately put down" $(299 ; 283)$. The novel features military-grade windups enhanced with super-human powers; agricultural workers given 
ten arms to increase efficiency; and elite model windups, such as Emiko, created to serve as personal assistants, sex slaves, and novelty items to powerful men. Like soldier-cyborgs, they are also designed to comply, as they are genetically engineered to crave subservience to a human master. ${ }^{33}$ These genetic impulses to serve are reinforced by intense training from birth to adulthood. Their genetics and training limit their abilities to make autonomous choices and pose the greatest challenges to others' conceptions of their humanness. Unlike generipped seed stock, New People have yet to fully penetrate global markets and are considered illegal and dangerous in many nation-states, including Thailand.

The plot of The Windup Girl documents the last days of the city of Bangkok. The story is told through the interwoven accounts of five protagonists: Anderson Lake, an American "calorie man" working undercover for AgriGen, a Midwest Calorie Company; Hock Seng, a "Yellow Card" Malayan refugee who works as Anderson's assistant in Anderson's shell kink-spring factory; Captain Jaidee, a.k.a. “Tiger of Bangkok, an agent of Thailand's Environment Ministry charged with keeping calorie men and windups out of Thailand; Kanya, Jaidee's underling who doubles as a spy for the Trade Ministry until Jaidee's death; and Emiko, an illegal elite-model windup abandoned in Thailand by her Japanese owner. The narrative begins in the midst of a long-standing power feud between Thailand's Environment Ministry and Trade Ministry.

The novel is set in a post-fossil-fuel economic period termed the "Contraction." An energy crisis caused by the terminal decline of fossil fuels following peak oil, which occurred during the "Expansion" period of the twentieth and twenty-first centuries, has crippled global trade. While rising sea levels have significantly diminished global landmasses (New York and New Orleans are under water while Bangkok is protected by massive dikes), calorie companies

\footnotetext{
33 New People's genetic impulse to obey is commonly suspected to be the result of splicing human and Labrador retriever genes.
} 
are responsible for the deluge of agricultural plagues that threaten humanity in the twenty-third century. In their pursuit of dominating the global market via the production of sterile seed stocks of staple foods, Calorie companies, or agri-biotech corporations of the Midwest Compact conglomerate-AgriGen, PurCal, UTex, and HiGro — have unintentionally unleashed wave after wave of agricultural plagues by eradicating seed variety and creating seed stock susceptible to "blister rust," "cibiscosis," "Nippon genehack weevil," "scabis mold" and other rapidly-mutable disease strains. These diseases have led to the extinction of the majority of the world's plant types, including most fruits and vegetables, and, as many of these diseases also infect humans, they have resulted in multiple devastating pandemics.

The calorie companies have also played influential roles in the collapse of most nationstates in a variety of other ways: ransoming their latest disease-resistant seeds in the wake of new plagues; letting countries starve by pulling staple seed stocks from countries over intellectual property disputes; unleashing poisoned seeds in biowarfare; and infiltrating nations with Midwest Compact embargos, stealing samples from national seed banks to use in future patented genehacks. As Andrew Hageman points out, the novel speculates about "the way devastating ecological consequences recursively result from and drive global economic changes" (283). The twentieth- and twenty-first century agri-corporation fervor to expand global trade economies at the expense of the environment results in both the trade Contraction and the Midwest Compact's monopoly of global seed stocks. Though this monopoly has led to rampant famine and disease, calorie companies now offer the only hope of human survival on the damaged planet by generipping ever-more plague resistant seed types. As noted by Scott Selisker, the novel does not offer its world a way to go back to the "natural," pre-expansion environment or to the resurgence of unmodified seed stock (504). The destroyer of the old world is positioned as the savior of the 
new, hyper-capitalist world order marked by war, famine, and the nation-state ceding power to a highly volatile and unregulated global economy.

Governed through an uneasy alliance between its Trade Ministry and Environment Ministry, Thailand is one of the few nation-states that have been able to refuse calorie company seeds and protect their national seed bank. The Environment Ministry is charged with protecting the country from infiltration by calorie companies and their products, as well as from invasion by Japanese New People. In essence, the biopolitical Environment Ministry is sworn to protect the health of the body politic from the threat of all invasive species: plant, human, animal, and New People. The Environment Ministry representatives Jaidee and Kanya are foiled by the Trade Minister, Akkarat, and his bioeconomic Trade Ministry who work to open Thailand to global trade of biocommodities, including calorie company seeds, in order to stimulate the economy. At the novel's opening, the Environment Ministry maintains a slight upper hand, though Trade is formulating a coup. Thailand has also employed Gibbons, alias Gi Bu Sen, a renegade Midwest calorie man and generipper who has successfully resurrected nightshades and other fruits from extinction in Thailand.

The narrative arc that unfolds from the confluence of the protagonists' stories is the Environment Ministry's decision, following the Trade Ministry's successful coup, to destroy the dikes protecting Bangkok in order to protect the country from a trade deal made between Akkarat and Anderson Lake's calorie company. Each of the five protagonists precipitates major events that culminate in the flooding of the "City of Devine Beings." Hock Seng, a Malayan refugee who despises his boss, Anderson Lake, manages Anderson's shell company, a factory developing a process to extract calories from generipped algae. Hock Seng spends his time trying to steal the factory's blueprints in order to sell them to Akkarat. Formerly a successful 
businessman in China before losing his family, home, and business to the Green Headband Muslim revolution, ${ }^{34}$ Hock Seng believes that he can again rise to social prominence—in essence overcoming his subrace status - if he can prove his worth to Akkarat. Early in the novel, Hock Seng discovers that the algae in Anderson's factory are responsible for a new wave of agricultural plague fatal to humans. He suppresses this information, placing the entire city, and potentially the world, at risk.

Anderson Lake, who is working to initiate a trade deal with Akkarat that includes access to Thailand's seed bank, is introduced to Emiko at a nightclub and brothel during his investigations into Thailand's recently developed generipped plant types. Anderson becomes infatuated with Emiko and begins buying her nights from the brothel's owner, Raleigh. Anderson tells Emiko about rumors of a windup-only enclave in the north where escaped windups live free. The possibility of freedom motivates Emiko to risk exposing herself in public in order to gain information about the windup village and secure travel arrangements. She finds herself in several life-threatening situations and consequently discovers that she has been designed with superhuman speed and strength. As she discovers more about her body and her abilities, she grows increasingly intolerant of her illegal status and nightly abuses at Raleigh's nightclub.

Meanwhile, Anderson learns that a successful deal with Akkarat and his ministry will require the blessing of the Somdet Chaopraya, the Child Queen's protector. Based on rumors that the Somdet Chaopraya is known to have "subversive tastes," Anderson takes him to see one of Emiko's nightly performances at Raleigh's. Predictably, the Somdet Chaopraya soon returns to Raleigh's with a large entourage that does not include Anderson. He pays for a private party, and he and his guests gang rape Emiko. The attack provokes Emiko to finally shirk her genetic

\footnotetext{
34 The Green Headband Revolution was a violent insurgency by a radical Islamic sect.
} 
impulses to obey, and she bare-handedly murders Raleigh, the Somdet Chaopraya, and his heavily armed entourage before fleeing the club. Significantly, she does not know who the Somdet Chaopraya is when she kills him. She escapes the club and flees to Anderson's apartment.

News of a windup massacring the Child Queen's protector quickly spreads throughout the city. Since neither ministry is aware of Emiko's presence in Bangkok, both ministries accuse the other of smuggling in a military-grade windup to assassinate the Somdet Chaopraya. Kanya, who has taken over the Environment Ministry following Jaidee's murder by Akkarat's men, launches an investigation and quickly uncovers the truth about who Emiko is and uses this information to quell the rising tensions between the two ministries. Though Akkarat believes Kanya's story about Emiko and promises to make peace with the Environment Ministry, he takes advantage of the moment's chaos to gain popular support for the coup he has been planning for some time. With the people of Bangkok cheering him on, Akkarat deploys an army of foreign mercenaries that had been lying in wait at Thailand's borders. The hired army quickly takes the city and Kanya surrenders her ministry to Akkarat's the following morning. Akkarat publically forgives Kanya, his longtime spy, and places her in charge of the new Environment Ministry. Her first duty is to escort representatives from Anderson Lake's calorie company into Thailand's sacred underground seed bank, officially inaugurating a trade partnership. Overcome by the guilt of Jaidee's death and fearing the ascension of Akkarat's ministry, Kanya makes an impulsive decision to take Akkarat down. As soon as she leads the calorie company reps underground, she executes them, gives orders to the Monks protecting the seed bank to evacuate the city with the seeds, and orders her troops to blow the dikes. The City of Divine Beings floods. Anderson contracts the plague Hock Seng had covered up, and Emiko nurses him until his death. The novel 
concludes with Emiko thriving alone in the drowned city. Genetically engineered to survive in an environment inhospitable to humans, Emiko makes a life for herself, a human life of freedom and choice, in the abandoned city.

\section{Selling Life in General}

Like The Giver, The Windup Girl dramatizes the perils of abolishing diversity through technology. Whereas The Giver's multiple generic and narrative ambiguities make it difficult to decipher the modern-day target(s) of Lowry's critiques, the targets of Bacigalupi's social commentary are explicit. His warmed, post-peak-oil planet clearly gestures to the growing body of irrefutable scientific evidence documenting fossil fuel's damage to the environment. However, global warming takes a back seat to Bacigalupi's warnings about the potential of genetically modified and patented agricultural products to irrevocably damage the environment. Bacigalupi penned his novel in the midst of heated international debates about the safety and environmental impacts of genetically modified food, as well as bourgeoning public fears of the seemingly endless legal and economic power of biotech seed corporations like Monsanto, Dow, and Pioneer. By weaving discussions of genetic modification into those of patriarchal sexism, racism, war, religion, neoliberal economics, and environmental catastrophe, Bacigalupi suggests that science developed primarily for economic motives will not be easily co-opted for humanitarian uses. Further, Bacigalupi complicates his warnings about the unchecked power of biotech corporations in his concluding suggestion that there is no return from here; though misused science may usher in environmental destruction and the end of humanity, participatory evolution through science is the only hope of survival in an already-irrevocably damaged and posthuman world. 
Tracing systems of power in Bacigalupi's dystopia can be as unwieldy of an exercise as untangling the cause-and-effect intersections of the novel's protagonists, and, in fact, the two processes are intertwined since each protagonist embodies a specific economic or political system vying for control of the twenty-third-century world. Extracting the processes of how power circulates through Bacigalupi's world highlights a complicated relationship between neoliberal and biopolitical systems. The two systems compete, each vying for power over the other and wielding their powers to diverging ends, but their individual powers are also inextricable from each other. The result is a merger of the two systems into a bioeconomy, a reigning power system in which human biology is commodified and the health of the market is conflated with, and ultimately supplants, the health of the body politic. Foucault, again, offers a helpful genealogy for understanding these transitions in his second and third biopolitical lecture series, Security, Territory, Population (1977-1978) and The Birth of Biopolitics (1978-1979).

As Thomas Lemke points out, one challenge to understanding Foucault's theories of biopower stems from Foucault's inconsistency in how he defines and applies biopolitical terms and theories (34). Within the body of Foucault's biopolitical thought, which includes Discipline and Punish, The History of Sexuality, and three lecture series, ${ }^{35}$ he defines and applies biopower in three different ways: "First, biopolitics stands for a historical rupture in political thinking and practice that is characterized by a rearticulation of sovereign power. Second, Foucault assigns to biopolitical mechanisms a central role in the rise of modern racism. A third meaning of the concept refers to a distinctive art of government that historically emerges with liberal forms of social regulation and individual self-governance" (Lemke 34). Biopower systems imagined in Bacigalupi's novel, while also demonstrating both of Foucault's first two applications of

35 Society Must Be Defended (1975-76); Security, Territory, Population (1977-1978); The Birth of Biopolitics (1978-1979) 
biopower, hone in on this third formulation of biopower as a disciplinary mechanism emphasizing "individual self-governance."

In his third formulation of biopower, Foucault steps away from his Nietzschean preoccupation with perpetual war in Society Must Be Defended and focuses instead on "governmentality," delving into a genealogy of the interrelated concepts of population and political economy that emerge alongside liberalism and consolidate within neoliberal systems. To borrow Sherryl Vint's concise summary, "Foucault outlines in The Birth of Biopolitics the process by which the population of people whose health the state was meant to foster were displaced by the aggregate understood as the economy itself, an entity whose health the people are now meant to serve" (Introduction 163). Liberalism introduces a series of biopolitical challenges: "How can the phenomena of 'population,' with its specific effects and problems, be taken into account in a system concerned about respect for legal subjects and individual free enterprise? In the name of what and according to what rules can it be managed?" (The Birth of Biopolitics 317). In other words, how can a liberal biopolitical system, which guarantees individual rights, encourages free enterprise, and pledges to safeguard the health of the body politic (i.e., population), achieve these three conflicting goals? Managing the demands of individuals, populations, and markets requires an "economic government" or "art of government" that seeks to answer "what makes government necessary, and what ends must it pursue with regard to society in order to justify its own existence?" (319).

While liberalism purports to answer these questions by "introducing into the art of government...the principle of self-limitation" in which the state only intervenes in order to safeguard lives or markets, unsurprisingly, "a reduction of state power in no way follows from this historical shift," and instead the state maintains, and even gains, power by disciplining each 
citizen as a homo economicus (Lemke 46). Gordon Hull notes that neoliberalism defines bios, or political existence, as homo economicus. As an "entrepreneur of oneself," the homo economicus "manag[es] risks and rewards as productively as possible," aiding the health of the body politic by managing his own economic health (326). This conflation of bios with economic capital and political existence evidences the simultaneous emergence of liberalism and bioeconomics, and suggests that bioeconomics is always already embedded in biopower. Bioeconomies in neoliberal systems, or "biocapitalist systems," measure economic profit against "organic capital," or human labor and life, as "human life does not serve as a measure of the economy but is itself subordinated to the economic imperative of valorization" (Lemke 107). Biocapitalist systems define a healthy body politic as an economy in which the exchange of economic capital for organic capital yields an economic surplus, and state expenditures on welfare projects are thus gauged against the human labor and life the state will receive in exchange (Lemke 105-115). This adds an economic element to superrace/subrace stratifications, allowing a previously subraced subject to overcome that status by proving her or his organic capital.

In much of Bacigalupi's world, biopolitics has largely ceded to bioeconomics, as nationstates bend to the demands and threats of calorie companies; however, Thailand has managed to limit the bioeconomic reach of calorie companies through an aggressive biopolitical program. Thailand's biopolitical agenda is expressed in the motives and tactics of Jaidee and Kanya and the Environment Ministry they represent. Perpetual wars still divide the world's surviving people into body politics, and the Environment Ministry is charged with protecting the health of the body politic from foreign and domestic threats. As a biopolitical agency, the Environment Ministry's power depends on the perpetuation of both interstate and civil wars. The Environment Ministry thus justifies its overreaches of power, namely its agents' routine practices of bribery 
and extortion, by propagandizing genehacking as the preeminent threat to Thailand's independence from international mega corporations. As such, the Ministry aggressively persecutes foreign "contamination" in all forms. To borrow Agamben's phrasing, Thailand maintains strict legal distinctions between "bare life" foreigners and the "political existence" of Thai citizens, and the Environment Ministry is given carte blanche power and resources to police Thailand's bare-life/political existence borders (Homo Sacer). However, even Thai's biopolitical bare-life/political existence divisions are expressed in economic terms. For example, Thai law insists on "Thai work for Thai workers," protecting the Thai body politic by denying foreign refugees the opportunity to become entrepreneurs of themselves.

Hock Seng best represents the merger of bioeconomics and biopolitics governing twentythird century Thailand, which recasts state racism in economic terms. Now one of thousands of Malayan refugees housed in Bangkok's abysmal refugee camps, Hock Seng was once a highly successful trader with many wives and children prior to the Malayan revolution. He saw all of his family slaughtered by Green Headbands, their heads cut off with machetes and stacked in piles in the streets. He managed to escape, and while his life in Thailand is far from ideal, he is luckier than most Yellow Cards as he has found employment as Anderson's assistant. Hock Seng's bare-life refugee status denies him legal protections, or, in Foucault's phrasing, marks him as a member of the subrace that threatens the health and well-being of the superrace body politic. However, Hock Seng's myopic focus to "secure" his future by embezzling factory money and working to sell factory secrets in exchange for economic security positions him as an homo economicus whose ethics and behaviors are motivated by economic self-interests. Hock Seng demonstrates this form of governance by equating political security with economic profit. As a refugee in a biocapitalist state, Hock Seng understands that care for his basic needs poses a threat 
to the health of Thailand's bioeconomy. He works to prove his "organic capital" in hopes that, if he is found economically valuable, he will be granted "political existence" despite his Malayan ethnicity. In short, he hopes to prove that his potential reward to the economy is worth the state's risk of investing in his life.

If Hock Seng represents the bioeconomic bare-life existence, Anderson Lake, a white American investor, embodies the privileges afforded to groups with high organic capital values. Though also a despised foreigner, the economic capital Anderson represents as a factory owner guarantees him the same legal protections as Thai citizens and grants him and his company legal exemptions and exceptions. However, Anderson's status is based on a lie. Anderson's factory, which produces algae-powered kink springs, is a front for AgriGen, a calorie company attempting to infiltrate the Thai market and access its seed bank, and Anderson is a calorie man. Anderson personifies the company and the market he represents. His myopic goal is to lead the world into another Expansion period in which calorie companies dominate and dictate the global market. Because calorie men pose such a threat to the health of both Thailand's bioeconomy and body politic, if exposed, Anderson would face a bare-life existence subordinate to even Hock Seng's. Whereas Hock Seng, Jaidee, Kanya, and Emiko are presented as complex, evolving characters, Anderson remains a one-dimensional figure of whiteness, Western patriarchy, and hyper-capitalism throughout the novel. Though he expresses nostalgia for the world his company and others like it have destroyed, he stops short of regret or guilt for his complicity. His onedimensional character and the economic and environmental threats he represents suggest that Anderson Lake is the preeminent subject of Bacigalupi's social critique.

Because foreign calorie companies, who peddle in biocommodies, pose the most eminent threats to the physical health of Thai citizens, entwined in Thailand's safeguarding of the body 
politic is maintaining the nation-state's economic independence in a globalized bioeconomy. In the world Bacigalupi has created, the lives and deaths of nation-states and their body politics are bound up in legal disputes over intellectual property rights. To a large extent, the biotech contexts to which Bacigalupi's novel responds begin with the 1980 Diamond v. Chakrabarty Supreme Court decision. The 5-4 decision expanded patent laws, which previously excluded patents of any form of life, to include "a live human-made microorganism," granting General Electric sole ownership of a bacterium designed to clean oil spills. While the court's decision made clear that patent expansions stopped short of covering human beings, as patenting humans would violate the Thirteenth Amendment, the decision neglected to address "genetically engineered human tissues, cells, and genes," and set a precedent for corporate ownership of a variety of man-made life forms and processes (Gray 117).

Since Diamond v. Chakrabarty, corporations and universities have received patents covering "transgenic nonhuman mammals," cultured human cell lines, and most frequently, genetically modified plant seeds (Gray 116-7; Vint "Introduction" 164; Barlett and Steele). Vint suggests that legalizing the ownership of biological life and biomedical processes recasts "the biological realm" as "a new site of economic expansion where biological processes and products are not only essential to the continued growth of world economies, but also increasingly understood only in these terms" ("Introduction 164). ${ }^{36}$ Bacigalupi's calorie companies and the bioeconomy they dictate, personified in the unyielding character Anderson Lake, forecast just such a world. By the time Bacigalupi began penning The Windup Girl, the effects of Diamond v. Chakrabarty were felt around the globe as American agri-biotech corporations expanded their global reach through the creation, patenting, and selling of genetically modified seed stock.

\footnotetext{
36 Vint is directly referencing the definition of "the biological realm" introduced in The Organisation for Economic Co-operation and Development's 2006 report, The Bioeconomy to 2030: Designing a Policy Agenda.
} 
Bacigalupi's Midwest Calorie Conglomerates evoke today's Monsanto, Dow, and Pioneer companies, warning of their potentials to monopolize global markets and wreak havoc on the planet. For example, the methods and tactics employed by AgriGen, Anderson Lake's employer, closely mirror the bullying tactics often attributed to Monsanto.

Monsanto, the makers of Roundup weed killer, entered the seed industry in the 1990s by creating Roundup-resistant plant seeds. When used in conjunction, Roundup and Roundupresistant seeds increase farming efficiency by allowing farmers to quickly spray agricultural fields for invasive weed types without risking damage to crops. Though the Missouri company began as an agrichemical company, Monsanto quickly saw the profit opportunities opened by Diamond v. Chakrabarty and began its transition to an agri-biotech powerhouse: "since the 1980s, Monsanto has become the world leader in genetic modification of seeds" and, as of 2008, "has won 674 biotechnology patents, more than any other company" (Barlett and Steele). The contracts farmers must sign when purchasing Monsanto's patented seeds have changed historical farming practices by forbidding farmers to save seed gathered at harvest to plant the next year, requiring farmers to purchase new seed annually. Monsanto aggressively defends its patents by employing undercover investigative tactics to scrutinize farming practices and legally bully both small and large Midwest farmers. Any farm found to be in violation of Monsanto patents or rules is aggressively prosecuted. Though many countries have banned Monsanto's seeds, as well as genetically modified seeds from other agricultural biotech conglomerates, Monsanto's financial and lobbying power, which have greatly influenced federal regulation of genetic modification processes and products, allows the company to operate in the US with near impunity. Monsanto 
monopolizes the US soybean market, claiming ninety percent of US soybean seeds, and its reach into other grain, vegetable, and fruit markets is steadily increasing (Barlett and Steele). ${ }^{37}$

Monsanto's legal power and ability to lobby for increased legal protections demonstrate ways the health of the market supplants the health of the body politic in biocapitalist systems, resulting in legal protections for corporations at the expense of citizens and consumers. Rather than the all-powerful state governing populations, the market, now trafficking in patented life processes and products, commodifies life itself. Whereas biopolitical systems gauge the health of the population based on its homeostasis, biocapitalist systems equate market health with exponential, limitless growth. In neoliberal systems that merge biopower with biocapitalism, the dystopian potential of state overreach is displaced by deregulated, all-powerful corporations that manufacture, and monopolize the markets of, biocommodities.

While Anderson and his company act as Bacigalupi's proxies for the potential for companies like Monsanto to cripple the world's food supply in the name of intellectual property and financial profit, Emiko and the New People she represents provide a glimpse of a world in which the Diamond v. Chakrabarty decision is fully extended. Calorie men and Yellow Card refugees evidence the continuation of what Foucault terms "biopolitical racism" and Agamben terms "bare-life existence" in bourgeoning biocapitalist systems. Like biopolitical racism, these newer systems make use of historical ethnic racism; however, diverging from biopolitical systems, bioeconomic and biocapitalist racism value and stratify groups based on the groups' perceived risk to the growth of the economy rather than, or in addition to, their potential risk to the health and homeostasis of the body politic. Hock Seng and Anderson Lake best represent the

\footnotetext{
37 Discussions of Monsanto's legal battles, congressional victories, and genetically modified products featured prominently in both US and international news media through the first decade of the new millennium, resulting in an explosion of critical exposés, such as Barlett and Steele's, and influential documentaries, such as Marie-Monique Robin's 2008 The World According to Monsanto and Robert Kenner's 2008 Food, Inc.
} 
subrace and superrace divisions of biocapitalist systems, yet neither represent the degree of barelife existence ascribed to Japanese New People like Emiko. As a living, female, nonhuman/human commodity in a patriarchal biocapitalist system, Emiko is subordinated to men, human subraces, and the economy. Whereas Yellow Cards and calorie men are despised and feared based on the degree of threat they represent to Thailand's body politic and bioeconomy, New People are feared as a threat to humanity itself. Because New People are legally defined as property, their threat to humanity is also managed in economic terms.

The Diamond v. Chakrabarty decision does not specifically exclude the patenting of genetically engineered human tissues, cells, and genes. By omitting mention of human organic materials, many, like Gray and Vint, fear Diamond v. Chakrabarty leaves space for the future patenting of transgenic, human/nonhuman hybrids, like Emiko. ${ }^{38}$ Such bare-life hybrid creations would fall victim to liberal democratic constitutions that base sovereign individual rights on conceptions of genetic humanness and could thus be vulnerable to intellectual property laws. Agamben's division between bare life and political existence legitimizes racism in the law by dividing 'the 'good,' healthy citizens and the 'bad,' unhealthy specimens, construed as fundamentally different from the citizen" (Vint "Introduction" 162). Bare-life-cyborgs suffer a second remove because they are divided from citizenship as well as humanness. This second division renders them both outside of human rights protections and within patent protections.

Speculating that the ability to patent seeds could eventually lead to corporations creating new transgenic slaves is an exercise in slippery-slope logic; however, Vint points to two recent trends that signal movement towards this possibility. She first notes the recent commodification of biological materials formerly classified as belonging to the "gift economy," such as "infant

\footnotetext{
38 Note: intellectual property laws limit patenting power to "transgenic nonhuman mammals," and today's bioethical mandates place limits on human/nonhuman transgenic projects.
} 
foreskins and aborted embryo stem cells," which are now sold by hospitals to corporations in a "tissue economy." She then points to the common locations of biomedical research facilities in socioeconomically depressed areas where companies can easily recruit subjects for paid clinical trials. While a long way from legal slavery, these two trends suggest ways bioeconomies are already capitalizing on systemic inequalities and challenging conceptions of what constitutes legally protected human life forms (Introduction 162-4). In other words, such trends evidence the recasting of bare-life/political-existence and subrace/superrace divisions in economic terms ("Introduction"). ${ }^{39}$ Emiko embodies and exaggerates these bioeconomic trends. Most obviously, she is a literal product of a biotech corporation. Like Monsanto's seeds, her elite-model design is patented by Yashimoto. More subtly, her creators exploit and exacerbate longstanding sexist and racist ideologies in order to create a product that appeals to the highest buyer, therefore embedding the maintenance of gender and race norms into the health of a biocapitalist market. Emiko's body is designed to satisfy the male gaze, she is racially marked as an exotic other, and she doesn't appear to age. While Emiko's idealized femininity and youth epitomize the ways women have been historically objectified and stratified by rigid gender norms in patriarchal societies, her status as a product, a commodity of a biocapitalist economy, highlights the historically concurrent economic functions of gender and race in liberal and neoliberal states.

Reminiscent of American slavery's one-drop rule, transgenic New People are the twentythird-century victims of a legacy of systemic racism enmeshed in a future hyper-capitalist global economy. Yet, racism and class divisions are not the only inequities worsened in the creation of New People, as Emiko and her "model" of New People bring to light the misogynistic

\footnotetext{
${ }^{39}$ Further, Vint points to the recent proliferation of zombie and vampire themes in speculative fiction, in which vampires and zombies have evolved from the historical supernatural beings to the twenty-first-century "images of genetic mutation and viral contamination," often at the hands of experimental biomedical corporations, as evidence of burgeoning cultural anxieties about the commodification of human biocapital.
} 
undertones of much post- and transhumanist enthusiasm that focuses on liberating the mind from the body. Born of a humanist legacy that equates humanness with maleness, Emiko's humanity is largely challenged on the basis of her designed subservience to a male master. Humanism has long privileged the mind over the body, and associated the mind with maleness and the body with femaleness. Emiko's genetic traits that are designed to stifle, if not eliminate, the mind and the will, subordinating her mind to her body, render her a nonhuman, female object of masculine fantasy.

\section{Humanist Posthumanism}

"Female cyborgs, while challenging the relationship between femaleness and technology, perpetuate oppressive gender stereotypes. This reading of female cyborgs raises interesting feminist questions. Can the 'feminine' essentialism of fictional cyborgs be transformed into a non-essential image for contemporary women? Is there any way that the cyborg image could be used strategically to intervene in feminist theory?"-Anne Balsamo, "Reading Cyborgs Writing Feminism"

"Whenever there is an advance in cyborg technoscience such as genetics, you can count on a gaggle of public commentators with nice hair to mention Frankenstein. Hardly ever do they differentiate between Dr. Frankenstein and the unnamed monster he created. Why is it so hard to remember that it is Frankenstein's monster who horrifies us? The conflation signifies that the doctor is monstrous in our minds" -Chris Hables Gray, Cyborg Citizen

Unlike generipped seeds and animal chimeras, New People have not yet influenced global markets or been accepted around the globe. Thailand, for instance, bans New People with the exception of New People accompanying (owned by) Japanese tradesmen and factory owners. As the Thai believe windups are soulless, New People offend Thai Buddhist sensibilities and are regarded as unnatural and inhuman abominations. New People discovered in Thailand without proper legal documentation can be killed with impunity. Grahamites-evangelicals from the US — and Green Headbands—-the radical Muslim sect now controlling much of China—similarly denounce the creation of New People as an evil and unnatural enterprise. Though these religious sects explicitly attribute their belief in the soullessness of New People to their transgenic human/nonhuman hybridity and "unnatural" laboratory births, as Selisker notes, New People's 
perceived genetic programmability ultimately underpins assertions that windups are nonhuman. Ironically, the measures Emiko's creators and owners take to ensure her inhuman status-i.e., her inability to make choices that serve her own interests - ultimately betray the potency of her innate humanness. As in The Giver, humanity in The Windup Girl is ultimately aligned with choice; however, while The Giver elides the ability to choose with knowledge of and participation in birth and death processes, The Windup Girl suggests that choice begins with an individual's instinct to survive. Further, a feminist reading of Emiko's struggle to claim her humanness in a human-dominated world suggests ways that historical humanist privileging of male bodies over female bodies can be rearticulated in posthuman worlds by hierarchically stratifying humanness and nonhumaness.

Yashimoto, Emiko's Japanese creator, has made his legacy generipping human/nonhuman transgenic beings to serve as a slave population for elite Japanese. Though the novel makes mention of windup agricultural workers as well as Japanese military windups aiding the defense of the Vietnam border, the two windups featured in the novel, Emiko and Hiroko, are both female New People designed to serve as personal assistants and companions to powerful Japanese men. Though New People serve a useful biopolitical function in Japan by working to maintain homeostasis of the population despite a significant drop in fertility rates, Japanese society implicitly shares some fears with other nation-states that condemn the New People enterprise, namely that New People could lead to the extinction of unmodified humanity. The most obvious symptom of this fear is the New People's genetically engineered impulse to serve. However, scientists betray doubt in their designs by coupling their transgenic splices with intense behavioral training. Yashimoto stresses, "How [New People] use their innate qualities is a question of their training, not of their physical capabilities" (300). New People are raised in 
training facilities and are not sold until they can demonstrate that they are fully disciplined and obedient servants. Through training, their genetically engineered impulses to serve are molded into taking pride in a spirit of absolute obedience to all humans and a strict adherence to decorum. Creators and trainers of New People also withhold information about New People's physical abilities and longevity. Windups are given augmented vision, superhuman speed, do not show signs of aging, are disease resistant, and live much longer lives than humans. However, they are not told of many of these abilities and are given no knowledge of their life expectancy. Emiko isn't sure how long she can expect to live, as she has never heard of a New Person dying of natural causes or old age. Scientists like Yashimoto also design New People's bodies with other genetic governors intended to ensure compliance with a master's demands. For example, female models, like Emiko, are given porcelain-like skin, "as soft as skin can be, and perhaps more so," with infinitesimal pores (35). Though owners find this trait aesthetically pleasing, the feature primarily functions to inhibit the windups' ability to exercise their superhuman strength and speed as they can easily overheat if required to exert prolonged physical energy. ${ }^{40}$ Even if a windup like Emiko discovers her speed and strength, her inability to sweat should limit the amount of damage she could do to human bodies before overheating.

New People are also designed to move in a way that highlights their nonhuman/human, man/machine hybridity. Their "stutter-stop flash-bulb strange" physical movements, to which the "windup" epithet alludes, betray their genetic makeup and mark them as bare-life transgenic beings (35). Selisker suggests that Bacigalupi adapts the windup's "human automaton" motions from science fictional film conventions. In cinema, actors moving "as though they are mechanical" signal that "they have been hypnotized, brainwashed, or programmed. In many

\footnotetext{
40 New People's resistance to aging highlights what Kathleen Woodward notes as a masculine-humanist fantasy to master nature through immortality and also feeds the Western privileging of youth over age.
} 
cases, this movement makes a visual comparison to mechanical dolls or automata, whose 'windup' mechanisms drive their movement" (507). Selisker notes that automata movements are both fascinating and uncanny, as "this aesthetic form arrests our gaze in the service of considering the nonhuman motors within the human" (508). In other words, Emiko's flash-bulb movements not only serve as a marker of her otherness, but also hold an unwelcome mirror to her human audience by asking us to consider the nonhuman motors — systems, ideologies, etc.propelling our choices and actions. Selisker's observations also align with Anne Balsamo's argument of the historical trajectory of cyborg iconography in sci-fi film and TV that often reinforce, rather than challenge, oppressive gender constructions. The image of an automaton doll, a toy, is a feminine one, a plaything created and controlled by man for his entertainment and pleasure.

Emiko's human/nonhuman struggles play out in an arena of genetic determinism vs. individual will. Humanness is thus determined by a person's ability to act in her own selfinterest. The men Emiko encounters express genetic deterministic faith that, like all New People, Emiko is incapable of disobedience, and thus incapable of agency. Put simply, they take her assumed inhumanity for granted. In addition to denying her political existence, her inhuman status also renders her body more vulnerable to sexual violence. Though the characters Emiko interacts with do not question her inhumanity, as they believe her to be incapable of making choices, the reader is immediately made aware of her constant inner conflicts between genetics and personal desires.

We are introduced to Emiko as she sips whiskey, wishing she were drunk, and waits for the signal from Kannika that it is time for her humiliation. A part of her still struggles against it but the rest of 
her - the part that sits with her midriff-baring mini-jacket and tight pha sin skirt and glass of whiskey in her hand — doesn't have the energy to fight.

And then she wonders if she has it backwards, if the part that struggles to maintain her illusions of self-respect is the part intent upon her destruction. If her body, this collection of cells and manipulated DNA—with its own stronger, more practical needs - is actually the survivor: the one with will. (34)

Before she is introduced as a New Person, she is described as a person with a will, a person capable of struggling against coercion. Though she is not sure which force is stronger, her will or her DNA/body, she doesn't question her ability to desire something in conflict with her creators' intents and designs. She envies the Cheshires, as they do not know their origins. She, however, is all too aware of how she has been "trapped" by an "irritating scientist with his test tubes and DNA confetti mixes" into a life of conflict between the services she has been designed to fulfill and the desires she has for self determination.

Emiko's struggles between her genetic instincts and personal desires are showcased in every one of her featured scenes; however, Bacigalupi resists making clear distinctions between her will, associated with her mind, and her genetics, or body. Aligning Emiko with Elizabeth Grosz's assertions that there is no boundary separating mind and body, Emiko often cannot distinguish between her conflicting desires or identify whether her mind or her body is compelling her actions. Though she "wills herself to resist," she often reflexively obeys harsh commands despite her intentions and "despises herself" when she "feels a wash of pleasure" after being praised for her obedience (45). The intense training she underwent during the first few decades of her life further blurs these distinctions. Emiko ruminates on her training under 
mistress Mizumi-sensei as often as she contemplates her genetics. In particular, Emiko thinks of Mizumi-sensei every time she is able to overcome her genetics and disobey or rebel. Though her genetics have instilled a desire to obey, her training has instilled the shame of rebellion. For example, when she bravely outs Anderson as being a Midwest Calorie Man during their first encounter, she scolds herself and imagines what Mizumi-sensei would instruct: "Even though Emiko is ashamed by the gaijin's prying into her history and by her own loss of control, Mizumisensei would say this is no excuse to prod and bait the man" (45). She has trouble shirking the training that has taught her to "obey, to kowtow, to bend before the desires of her superiors, and to be proud of her place," and thus feels deep shame anytime she risks impudence or disobedience.

After meeting Anderson, Emiko's inner struggles intensify. Anderson attempts to give Emiko money as payment for her information on Gi Bu Sen. Emiko, again shirking her training, resists the money and snaps that money will not help her as she is owned by Raleigh. Anderson asks her why she hasn't tried to run to the New People in the North, and, after Emiko expresses ignorance, he tells her that enclaves of runaway New People are hiding in the northern mountains, where they have built villages and live free lives. They live in brutal conditions, as the jungle has been "genehacked half to death," and they risk being caught in ongoing coal wars, but they are free (46). Knowledge of this community of New People motivates Emiko to escape and intensifies her will to disobey and defy both her genetics and her training. She spends equal time fantasizing about life in the New People village and despising those in the village for living shameful, selfish lives apart from their created purpose as servants. Significantly, she grows to recognize that "she has been enslaved to think against New People, even when she herself is one of them" (155). She also welcomes Anderson's attentions as a kinder, safer alternative to Raleigh 
and Kannika, but struggles against a growing hatred for her need of a savior or patron. With this hatred comes a deep resentment towards the scientists who made her as well as a resentment toward those who question her humanity.

Emiko slowly begins to consider her genetics and the abilities they give her-she has discovered her super-human speed that Mizumi-sensei neglected to mention in her training-as giving her an advantage over other humans and begins viewing her "masters" and creators as pathetically slow, weak, and susceptible to death. She begins taking chances by leaving her apartment during the day, risking exposure, to query about travel arrangements. She also braves asking Raleigh about the New People in the North, making clear her desire to go, which he flippantly agrees to do when she has paid off her debts.

Just as a human/nonhuman hierarchy determines Emiko's legal status, and thus acts as the preeminent marker of her bare-life status in a posthuman future, her female body subjects her to historical gender binaries. Her posthuman DNA subordinates her to all non-enhanced humans while her womanhood positions her as an object created to satisfy the male gaze. Her status as a posthuman woman dramatizes the fears of writers, such as Dan Bruiger, Chris Hables Gray, Elizabeth Grosz, N. Katherine Hayles, Ann Balsamo, Thomas Foster, and others, that dreams of a posthuman future are too often built from the foundations of humanist hierarchies that privilege the mind over the body and align the mind with maleness and the body with femaleness. Furthermore, Emiko's body demonstrates Vint's concerns that in a posthuman future, the markers of femaleness that subjugate women in a humanist system will be readapted as nonhumanness in a human/nonhuman binary that privileges humanness. The two generippers we meet in the novel, Gibbons and Yashimoto, embody the characteristics of hypermasculine posthumanist enthusiasts. 
Gibbons, in particular, embodies the fears of Gray and Bruiger, both of whom caution against advancing human evolution and environmental change in service to a hypercapitalist global economy. Gibbons shares many of Gray's views regarding participatory evolution and an inevitable posthuman future, but rather than acknowledging the grave responsibility that comes with knowingly advancing human evolution and environmental change, which Gray insists upon, Gibbons views the ability to tamper with the future of humanity as equivalent to harnessing the power of God: "We are nature. Our every tinkering is nature, our every biological striving. We are what we are, and the world is ours. We are its gods" (243). Bruiger directly addresses this masculine desire to play God, arguing that conquering nature has played crucial roles in environmental destruction, the subjugation of women, and economic globalization. Gibbons epitomizes Bruiger's concerns, as his genehacks fuel the global seed market and are largely responsible for the many agricultural plagues and resulting plant extinctions around the globe. Rather than take responsibility for the devastating impacts his inventions have had on the environment and human populations- - I built the tools of life. If people use them for their own ends, then that is their karma, not mine" (245) - Gibbons suggests that how the world got to this point is irrelevant. It has now evolved to the point where humans will not survive in any form unless they are willing to "unleash" their "full potential" and actively change and modify themselves and their food sources (243): "Nature has become something new. It is ours now, truly. And if our creation devours us, how poetic will that be?" (246).

While Gibbons and his creations are tied to the destruction of the environment caused by the pursuit of a hypercapitalist global economy, Yashimoto's creatures point to the gendered nature of man's desire to play God. When we first meet Emiko, she appears to fulfill hypermasculine fantasies of using cyborg technologies to create the "perfect" feminine woman. She is 
living in Thailand illegally, as her former owner, Gendo-sama, who was doing business in Japan, chose to leave her in Thailand after completing his job rather than paying the high price of a ticket to take her home. He left her in a hostile country without legal documents to protect her, explaining that he intended to "upgrade" to a "new model" when he arrived in Japan. Despite this betrayal, Emiko craves her master and perceives her separation from him as unnatural. She is nostalgic for her time with Gendo-sama, longing to again give him the pleasure of her obedience. She has since found a new master, her pimp Raleigh, who owns a strip club and brothel and agrees to protect Emiko in exchange for her services. The Thai people despise New People, but subversive sexual and sadistic desires often lurk beneath their hatred and fear of "soulless" windups. In short, she is one of Raleigh's most profitable assets. Her services include nightly performances before jeering and cruel crowds, followed by private "dates" with any man who has paid Raleigh. Many of these men are "white shirts," or Environment Ministry employees charged with protecting Thailand from infiltration by New People. Though Raleigh does not pay Emiko for her services, he provides her with ice, an expensive commodity, resulting in a debt she can never work off.

The degree to which female New People have been generipped to satisfy male desires becomes apparent when we first meet Emiko. As earlier described, she is sitting at Raleigh's bar, sipping whiskey, dreading her imminent "humiliation" at the hands of Kannika, Raleigh's prostitute who has been charged with abusing Emiko on stage every evening. As Emiko sips and ponders her old life with Gendo-sama, Kannika violently breaks her reverie by grabbing her by the hair and dragging her on stage. Kannika fuels the crowd by stripping Emiko and pouring water on her body, causing Emiko's "herky-jerky heechy-keechy" reactions. The crowd roars and begs for more as Kannika forces Emiko to her knees and pours beer down her throat, causing 
Emiko to choke and convulse. Kannika then encourages men in the audience to hold Emiko's legs as Kannika rapes her with a "jadeite cock." Though she is humiliated and in pain, "Emiko moans again as her body betrays her. She cries out. Arches. Her body performs just as it was designed - just as the scientists with their test tubes intended. She cannot control it no matter how much she despises it. The scientists will not allow her even this small disobedience. She comes" (38). The scene leading to Emiko's rape is filled with references to Emiko reflexively "obeying" Kannika and the crowd. In a twist of cruelty, scientists have designed her instincts to trigger most when being commanded by strong, authoritative figures. Regardless of the situation, people who speak with the most authority, such as Kannika and Raleigh, best incite Emiko's subservient instincts. She craves a master—not a companion, friend, or lover.

Despite her original master's neglect, the nightly abuse she receives at the hands of Raleigh and Kannika, the high price men are willing to pay for a night with her, and the constant deadly threat of exposure she faces when traveling to and from her lodging and Raleigh's bar, Emiko's relationship with Anderson Lake best exemplifies her designed purpose as a man's exotic plaything. Emiko and Anderson meet when Emiko is summoned to Raleigh's private office following her performance with Kannika. Raleigh summons her to disclose a recent conversation she had with a white shirt client regarding a generipper known as Gi Bu Sen. Anderson, who is looking for Gibbons and suspects Gi Bu Sen to be an alias, is shocked to see a windup in Thailand, as Thailand's hostility toward New People is well known. Though their initial meeting at Raleigh's is brief, Anderson is fascinated by Emiko and can't get the meeting out of his mind. By chance, the two collide in the street weeks later when Emiko, running from a Thai man bent on killing her after spotting her stutter-stop motions, sees Anderson's rickshaw and runs to him. She is near dead from overheating when she gets to him and he takes her to his 
home. After weeks of Emiko going to Anderson's after her nightly duties at Raleigh's, Anderson begins buying many of her evenings from Raleigh. The two maintain their relationship throughout the course of the novel.

For Anderson, Emiko is purely an object of fascination and fetishization. In addition to her inhuman characteristics, Anderson's objectification of Emiko is grounded in legacies of patriarchy and western exoticism of eastern otherness. Though he admires aspects of her personality, ultimately, her body and its abilities capture his gaze and motivate his actions. This becomes most apparent when Anderson, to close a business deal, takes the Somdet Chaopraya to see Kannika and Emiko's nightly performance. Though Anderson does not physically mistreat or abuse Emiko as others do, and grants her more human qualities than does any other character, Anderson still views Emiko as an object and a tool - a nonhuman, female being created to serve and please men, a slave in need of a savior and a master.

The climax of Emiko's story occurs at the moment her will finally overcomes both her genetics and her training. The Somdet Chaopraya returns to Raleigh's, along with an entourage, and demands a private Kannika/Emiko show in which Kannika, with the help of the most powerful man in Thailand, anally rapes Emiko with a champagne bottle. Under the intensity of the fear, pain, and humiliation she feels, Emiko thinks "if there is any falcon in Emiko at all, if it ever existed, is a dead thing, dangling. Not meant to live or fly or escape. Meant to do nothing but submit. Emiko learns her place once again" (257). She begins begging Kannika to let her obey, to "let her live just a little longer," to which Kannika "laughs and laughs" (257). After the show, Emiko sits on the barroom floor "exhausted and broken...Inside, she is dead" (257). Raleigh scolds her for her ungrateful pouting, and she begins mouthing off. She initially believes that the part of her she considered to be her will, her desire for life, has died; however, as Raleigh 
adds his abuses, assuring her that she will never escape to the North, a deep instinct, to survive at any cost, usurps her genetic inclinations to serve and rages forth. Moving with super-human speed and strength, she rips Raleigh's throat out with her bare hands and then storms into the VIP room still hosting the Somdet Chaopraya and his private party: "Men look up with surprise. Heads turn, mouths open to cry out. The bodyguards are reaching for their spring guns, but all of them are moving too too slow. None of them are New People" (259). All eight men in the room soon share Raleigh's fate.

Though, as readers, we celebrate Emiko's revenge and champion her evolution from subservient being to autonomous person, within the logic of the world Bacigalupi has created, she "proves" her superrace oppressors right. She is a threat to the body politic of the superrace of natural humans. She can outmatch them individually and she, along with other windups who escape their bondage, will outlive them collectively. Finally freed from her training, she becomes exactly what the Thais, the Grahamites, the Green Headbands, and, ultimately, Yashimoto and the Japanese, fear: in an environmentally damaged and disease-ridden world, genetically altered, human/nonhuman transgenic "creatures" are more adapted for survival than unmodified humans. She has come to view humans as a weak, easily discarded species and has claimed ownership of her new world. Her revenge will come at a cost to other New People, as she will be held as an example of the threats New People pose to the health of the superrace. As fears of New People rise, the superrace will look to the state for protection against this insurgent threat, ceding a few more rights and freedoms in the process. This is immediately seen in the civil war that erupts following Emiko's brutal revenge.

In an ultimately futile attempt quell hostilities between Environment and Trade, Kanya visits Yashimoto to get background information on the presumed military-grade windup. 
Significantly, after hearing Kanya's news that Emiko has gone rogue, Yashimoto does not cite her genetics as the source of his surprise at her ability to disobey, but rather, her training: "It is surprising though, that one has shaken off her training. Unwelcome news. New People serve us. It should not have happened" (300). He assures Kanya that Emiko is not military grade and that, according to his records, she was "destroyed according to requirements, rather than repatriated" after Gendo-sama abandoned her in Thailand (299). The conversation between Yashimoto and Kanya is relayed through Hiroko, Yashimoto's personal windup. While the exchange between Kanya and Yashimoto highlights the role of training in New People's life of obedience, Hiroko's infinitesimal reactions to the information Yashimoto shares subtly counter his faith in the effectiveness of New Person training. When Yashimoto reports that Emiko was destroyed as required, Hiroko's “voice breaks off... she straightens and her eyes flick to Yashimoto.” He silently reprimands her break in decorum without registering its significance.

Hiroko's fate as a New Person is not the only detail about her life that has been withheld from her. When Kanya demands to know how a non-military-grade windup could kill eight armed men with her bare hands, Yashimoto, without warning, picks up his teacup and throws it at Hiroko's face: “The windup girl's hand blurs. The teacup smacks into her palm. The girl gapes at the cup in her hand, as surprised, apparently, as Kanya" (299). Yashimoto then explains that all New People are as fast as Emiko, but their training determines how they use their genetic abilities. He also credits their small-pore, porcelain-skin as a governor of sorts, as prolonged exertion at fast speeds would kill them. However, Hiroko's surprise at her ability, much like Emiko's surprise when she discovers her speed, belies Yashimoto's claims. New People aren't trained to control their speed; they are never educated of their abilities. After the teacup demonstration, Kanya asks if Hiroko is as physically capable of killing as Emiko. For the second 
time, Hiroko breaks with decorum and pauses in her translation to "jerk" at her master before answering, "Yes. It is possible" (300). While the news of her speed and strength are certainly surprising to her, Hiroko's second shock comes with Yashimoto's confirmation that it is possible for a windup to shirk training, defy genetics, and act of her own accord. She, too, is capable of choice.

Generippers like Yashimoto place complete faith in the combination of genehacking and training to eliminate New People's survival instincts. The will to survive is the ultimate selfish compulsion, and such urges oppose a New Person's purpose of selfless service. Even in Japan, where New People are accepted and prized, their acceptance is contingent upon their assumed inability to pursue self-interests or make autonomous choices. Most crucially, New People cannot place their own lives above their master's or any other human's, as nonmodified humanity fears that New People's abilities and disease resistant genes could lead to the extinction of humans and a new world of windups. While Emiko's actions give credence to this fear, her circumstances of abandonment and abuse give Yashimoto a plausible explanation for her extraordinary disobedience; however, Hiroko's momentary flick and hesitancy to translate what she now knows will be her fate - to be "destroyed" when "she has fulfilled her duty"suggests the will to survive hasn't been eliminated or deeply suppressed. The fact that New People aren't told of their eventual fate hints that Yashimoto also doubts the effectiveness of genehacking and training to kill survival instincts.

Though she doesn't realize it, Emiko's survival instincts have been motivating her behavior for a long time. The abuse she puts up with guarantees her survival. As a patronless windup, she has no official purpose. According to New Person doctrine, she should seek a new master or seek self-destruction; however, she resents her new "masters" and does whatever is 
necessary to survive. She runs away from persecutors in the streets, though her training and genetics should make it impossible for her to disobey them. She manipulates Anderson hoping that he can help her move North, and she attempts to make arrangements to escape, defying Raleigh's orders. The moment she fears the falcon within her dies at the hands of Kannika and the Somdat Chaopraya's abuse is the moment she actually gives in to her "selfish" desire to live, begging for life. After she exacts her revenge, she comes to fully embrace her will to live. Days after the murders, she is trapped in a crowd on the street. Her instincts to survive have now fully overcome her trained responses, as she has no urge to obey or comply; rather, her "first urge is to slash her way free, to fight for survival, even though there is no hope of escaping the crowd before she overheats. I will not die like an animal. I will fight them. They will bleed" (293). The humans she once compulsively protected and obeyed are now "them," others, non-New People, who stand the way of her desires.

\section{A New Eden}

"Cyborgs thus represent a paradox: they are potentially better than human and they threaten the loss of our identity - if we become too much the cyborg, will we no longer be human? Serving as both enhancers and mutilators of what went on before, cyborgs - and especially cyborg modes of reproduction-represent, in another of Haraway's potent phrases, a 'promise of monsters."' -Robbie Davis-Floyd and Joseph Dumit, Cyborg Babies

After Emiko murders her tormenters, she flees to Anderson's apartment for shelter. She is covered in blood and horribly upset, and refuses to explain her situation. Soon, the trade minister Akkarat and his henchmen come to Anderson's apartment looking for the windup. She escapes through the window, and Akkarat kidnaps and tortures Anderson, blaming him for the assassination as he introduced the Somdet Chaopraya to Raleigh's club and his windup. Over the next day, due to Kanya's investigations, both ministries come to realize that the windup was not a hired or trained killer. However, Akkarat takes advantage of the city's hostile environment, 
bringing in hired foreign military and attacking the Environment Ministry. After a brutal coup, Anderson is released and Trade is in power and has waged an agreement with Anderson's company, AgriGen, to share Thailand's treasured seed stock in exchange for non-sterile, disease resistant AgriGen seeds. Kanya is promoted to General and is placed in charge of the Environment Ministry. In a spontaneous decision, she orders her men to kill the AgriGen representatives while in the seedbank, instructs monks to move the seedbank to a secure location, and orders the environment ministry to destroy the dikes protecting Bangkok. At the novel's conclusion, Kanya is considered the new Tiger and savior of Thailand, the Environment ministry is back in power, and the "city of divine beings" is underwater.

The novel's epilogue introduces a brave new world. In the days following Anderson's release from Akkarat, he and Emiko hide out in his apartment. He is dying from a new disease strain and lives his remaining days coughing up chunks of his lungs and incoherently hallucinating. His prophetic death signals an eminent future earth uninhabitable by humans. As a prominent company man, Anderson is inoculated from all known agricultural plagues. His illness, caused by a newly mutated virus strain, suggests that generipping scientists cannot keep up with, or defend against, the ripple effects of their genehacks. Emiko stays with him until he passes, then moves to a recently abandoned apartment and stays in the drowned city. She begins embracing her new, free life. Her speed makes fishing and hunting easy, and, as she is surrounded by water, she has no fear of overheating. She decorates her apartment and becomes comfortable in her new world. Though there are a few remaining people in the city, most leave her alone. Those who attempt to "prey on a lone girl's perceived weakness" are dealt with "quickly, and with as much mercy as she knows how" to show (356). 
As she now enjoys her body and her abilities, and no longer regards herself as inferior, she despises the scientists, who "learned too much from cheshires" and designed all New People to be infertile (114). Like her smooth skin, her infertility acts as a safeguard, a governor, to ensure that New People will never replace humans. Though she now views herself as superior to humans in both ability and character, she also perceives that she is incomplete, missing the ability to create life and leave legacy that seems inextricably tied to her instincts to survive and live. One day, as she washes her laundry on an apartment balcony now at sea level, an old, decrepit foreign man and a young girl float by on a boat with their evening's meal, a recently killed Cheshire. The old man is Gibbons, and his companion, who Emiko initially considers to be female, is a "ladyboy" genehack, or a "boy and girl, together." Gibbons recognizes Emiko’s "design" and asks to dine with her. As the group shares a meal overlooking the drowned city, Gibbons reveals that he is like the scientists who made her. He regards her obedient genes as a "shortcut" the scientists took in their creation of New People and expresses sympathy: "It's a hard thing they have done to you" (357). When Emiko spits, "I hate your kind," Gibbons reacts, “I'm surprised you aren't more pleased to meet me. You're as close as anyone ever comes to meeting God. Come now, don’t you have any questions for your God?” (358).

The full force of Emiko's new hatred of humanity serves as her answer: "If you were my God, you would have made New People first... We would have beaten you. Just like the cheshires" (358). Gibbons, rather than recoil from her abuse, replies "you may yet," and then assures Emiko that, though he cannot give her the organs her creators' denied her, he can make fertile children from "a strand of your hair," children that would be "a part of the natural world" (358). He can give her a legacy. Gibbons, who earlier expressed to Kanya and Jaidee that "we should all be windups by now," sees no divide between nature and culture, and thus sees New 
People, cheshires, and blister rust, megodonts, and patented TotalNutrient wheat as all part of the natural world. The epilogue concludes with an image of a new, revised Eden. Gibbons, the selfdescribed God of the new world, sits with his creations, a transgenic windup and a male/female companion, promising to populate the earth by taking a part of Emiko's body, like Adam's rib, and creating new life. Rather than a new Eve, we are left with a Lilith, a woman who refuses to be subservient to men and promises to outlive human gods.

While Bacigalupi makes use of many gendered cyborg tropes and motifs Balsamo identifies, such as Emiko’s skin, doll-like movements, sexual subservience, and designed purpose as man's plaything and helpmate, he ultimately leaves us with an image that gestures towards Haraway's "illegitimate offspring" that "are often exceedingly unfaithful to their origins. Their fathers, after all, are inessential" (151). In the process, by documenting Emiko's journey from subservience to autonomy, and thus from a programmed inhuman to a person capable of making choices and acting in her own interests, Bacigalupi aligns Emiko with Vint's assertions that the SF cyborg has the potential to disrupt humanism's patriarchal hegemony by recasting male/female, mind/body, and culture/nature binaries as divisions between humanness and nonhumanness. If, as Vint claims, humanness is aligned with maleness, Emiko, as a creation of masculine (human) fantasy and fetish, should fall outside the boundaries of humanness; however, Emiko's constant struggle between her will and her genetics blur and challenge the boundaries separating the Emiko scientists intended to create and the Emiko who incites a civil war and stands alone as the mother to a new world.

Motivated equally by economic profits and masculine-humanist fantasies, the Gibbons and Yashimotos of Bacigalupi's world created a slave class of bare-life-cyborgs designed to serve and obey; however, in their attempts to play God and find immortality by harnessing 
nature, generippers gave birth to offspring they could not control. Though generippers' creations have destroyed the environment, led to the extinction of most plant life, unleashed plagues, and dismantled nation-states, Bacigalupi closes his dystopia with a eutopian glimmer. In a world now hostile to humans, humanism's hegemonies have lost their teeth. As Emiko's humanness is no longer in dispute at novel's end, as she is no longer programmed, Bacigalupi's cyborg answers Vint's call for an ethical posthumanism that applies the post- to humanism rather than human. In their attempts to create a feminized servant that falls outside of the protections of human rights laws, generippers of New People have created a class of persons no longer bound by humanism's dualities. While her genetics do not grant Emiko legal protection or citizenship in a biopolitical and bioeconomic system, they challenge liberal humanism's very foundations.

Though the eutopian turn in Bacigalupi's epilogue is more distinct than those in Atwood and Lowry's conclusions, eutopian hope for Emiko is still mired in humanist tendencies that could impede, or prevent, an ironic liberation for her and her children. Most apparent is her dependency on Gibbons, a man who refers to himself as her god, to "father" her future "children." At this moment, he is essential to her wish fulfillment of a genetic legacy. Further, the slippery alignment of Emiko becoming more fully human with her ability to "mother" genetically related offspring echoes historical essentialist discourses, including feminist discourses, that too often equate womanhood with childbirth and motherhood. Though Gibbons will use science to engender Emiko's children, and though her children will genetically be nonhuman/human hybrids, the image of Gibbons gifting Emiko children, a gift that will help her feel more complete, smacks of heteronormative "happily ever after" iconography. The inhuman (i.e., woman) becomes more human by becoming a mother. Bacigalupi's epilogue does invite the reader to dream of ways for Emiko to create a new origin story for life in a posthuman world, an 
origin story that shirks ideas of original unity in an edenic garden. Gibbons's transgentic engineering expertise, and his proclivity to alter and hybridize anatomical sex, evokes Haraway's vision of a "world without gender" opening the door to a "world without end." However, the image we are left with also evokes edenic imagery in uncomfortable ways-a woman, being tempted by a man claiming to have the powers and knowledge of God. Thus, the reader may just as easily envision Emiko's choice as a deal with the devil that precipitates a second Fall.

As an appropriated symbol of masculine-technoscience, perhaps, as Balsamo fears, Emiko and other bare-life-cyborgs will be too easily conflated with historical gender-conforming cyborgs to yield immediate emancipatory results for women. After all, Emiko will probably face hostility and hatred from unmodified humans for the remainder of her life, and, though she no longer depends on a male patron for survival, her hope for legacy still depends on an uneasy alliance with the male scientists she hates most. The closing scene is both unnerving and hopeful, as the world is left to the unlikable, but undeniably powerful, Gibbons, his compliant companion who satisfies his fancies, and a likeable, but vulnerable, cyborg. However, the eutopian glimmer in Bacigalupi's novel opens the possibility of a better world, not for Emiko, but for her future children. Gibbons, though powerful, is old and weak. Emiko and her children will outlive their God. Emiko's children represent the long and perilous process of posthumans learning to deny inessential fathers. As Octavia Butler's Lilith and her brood will demonstrate, furthering equality and justice through post- and transhumanism may require multiple generations of cyborganization. Today's cyborg may still be trapped in yesterday's systems, but, like Emiko, the cyborg is better equipped to survive and thrive in the posthuman world their fathers are quickly creating. 


\section{Chapter 5}

\section{Lilith's-Children in Octavia Butler's 1987-89 Xenogenesis Trilogy}

Come near, you nations, to listen and pay attention, you peoples!

Let the earth hear, and all that fills it; the world, and all that comes out of it.

For the LORD is angry against all the nations, and furious against all their armies.

He has doomed them to destruction, and given them up to be slaughtered....

For the LORD has a day of vengeance, a year of recompense for Zion's cause.

Edom's streams will be turned into burning sulfur, and its dust into sulfur

its land will become pitch.
It will burn night and day, and will never be extinguished.

Its smoke will rise from generation to generation, and it will lie desolate forever and ever.

And no one will pass through it.

They will name it "No Kingdom There," and all its princes will come to nothing... And desert creatures will meet with hyenas, and goat-demons will call out to each other. There also Liliths will settle, and find for themselves a resting place.

—_Judgment of the Nations." Isaiah 34:1-14, SIV

Lilith. Lilith's origin story is fragmented, contradicting, and obscure. In Isaiah, she is a ruin dweller, the inhabitant of a desert world destroyed by God's vengeance and wrath and no longer suitable for humans. In the Talmud, she is referred to as the mother of demons and described as a longhaired, winged creature that attacks humans as they sleep. She shares traits with two other demons, Ardat Lili, a succubus, and Labratu, a vampiric creature who kills children with her long hair in order to suck their blood. In the Midrash, she is Adam's lover while Eve mourns her son Abel. The children born of Adam and Lilith's sinful affair are demons. In some midrashic texts, she is also occasionally conflated with the queen of Sheba, a halfhuman, half-demon jinn. Perhaps the most common ideation of Lilith comes from the $10^{\text {th }}$ century midrashic text, Alpha Beta de'Ben Sira, which describes Lilith as Adam's first wife. Lilith was, like Adam, created from the dust of the earth. As such, she considers herself to be Adam's equal and refuses to assume a subordinate sexual position. When Adam hesitates to comply with her demand that he adopt a submissive position during sex, she flies from the garden to the sea, abandoning Adam. God sends three angels to bring Lilith back to the garden. She refuses to return. God punishes Lilith by killing 100 of Lilith's children every day. In 
revenge, Lilith comes in the night and kills human babies, both inside and outside of the womb, as well as laboring mothers (Pintel-Ginsberg). Consistently, Lilith is hybrid, liminal, and monstrous. She is subversive, vengeful, sexual, and powerful. She is the mother of nonhuman, often fatherless, beings. And, according to Isaiah, she will inherit the earth after humans' fated apocalyptic return to dust.

In Octavia Butler's Xenogenesis Trilogy, the Lilith of Jewish folklore is re-imagined as an African-American woman who awakens on an alien spaceship two and a half centuries after the earth was destroyed by nuclear war. ${ }^{41}$ The namesake of monstrous motherhood, Butler's Lilith stares into the ruins of humanity's apocalyptic failures and reluctantly, partly through coercion and partly by choice, spawns a posthuman genesis on a cyborgian earth. Lilith will eventually give birth to transgenic posthumans who have the ability to finally break from humanity's dualistic tendencies; however, Lilith's story is the story of a mother-soldier. She is both captured and saved by the Oankali, an alien species that act as biopolitical soldier-cyborgs. The male and female progeny of these two biopolitical species, human and Oankali, at first assume a bare-life-cyborg status as outsiders, relegated to the boundaries that separate Oankali and human societies. It is with Lilith's first ooloi child, Jodahs, a third-sexed hybrid capable of genetically engineering the new Oankali/human “construct” species, that Butler's trilogy embraces the eutopian power of Haraway's ironically liberated cyborg. This process, from mother-soldier to Lilith's-children, takes centuries. It's messy, violent, sad, and hopeless at times; but by granting her characters unusually long lifespans, Butler is able to move through long durée dystopian results of biopolitical attempts to control "life in general" in Dawn and Adulthood Rites and introduce a new, potentially eutiopian cyborg image in her concluding

\footnotetext{
${ }^{41}$ In this chapter, I will be citing Lilith's Brood, the collected trilogy in one volume.
} 
Imago. Butler thus presents a range of biopolitical cyborg manifestations in her suggestion that a more eutopian world is possible, but it will come at the cost of humanity as we know it.

Like the trilogy it analyzes, this chapter has many moving parts. As in the previous chapter, I will begin by providing a thorough summary of the three novels. I will then turn to a discussion of the ways Butler uses her work to expose the eugenic undercurrents coursing through late-twentieth-century discourses about genetics and ARTs. This discussion will springboard my analysis of the Oankali species as unwitting biopolitical soldier-cyborgs who justify their "benevolent" imperialism of other species and planets through genetic essentialist dogma. Through brief readings of Lilith and Akin, the featured protagonists of Dawn and Adulthood Rites, I will explicate the figures of mother-soldier and bare-life-cyborgs respectively. I will conclude the chapter by introducing the Lilith's-children manifestation of biopolitical cyborgs in my analysis of Jodahs. My reading adds to Xenogenesis scholarship by suggesting that we view the Oankali and human species as mirrors rather than foils, operating as the two poles of a hierarchically oppressive opposition and evoking humanism's binary structures. Jodahs, then, represents the eutopian hope of a better, more just future for both species and the worlds their hybrid descendents may encounter.

\section{A True Xenophobia and a New Xenogenesis}

Dawn opens with Lilith Iyapo's violent re-awakening from suspended animation. She has been awakened like this several times over what she perceives to be a long span of time, perhaps years. Sometimes she is left awake for days, weeks, or months. While awake, she is kept in small, strange rooms. The lighting seems unnatural, yet it doesn't seem to originate from an electrical current. Though her rooms often have sleeping platforms, chairs, and tables, the 
furniture joins seamlessly to the floor and the walls. The materials are the same; it's as if the furniture grows from the floor. When Lilith awakens, naked and alone, she is questioned by an unthreatening voice that seems to come from the ceiling, though Lilith can't see any speakers or vents. Lilith also suffers from memory loss. She remembers her life before nuclear war rendered the earth uninhabitable. She remembers her young son and Nigerian-American husband who died in a car accident before the war. But her memories between the spaces of bombs going off and her first awakening are inaccessible to her. She has a new surgical scar on her abdomen, and she has no idea where she is or who is holding her captive.

We find out, along with Lilith, that this is to be her final re-awakening. The disembodied voice she has grown accustomed to suddenly manifests in her room in a fully embodied alien, an Oankali male named Jdahya. Lilith viscerally reacts to his presence. She is both terrified of and revolted by him. Jdahya's body is covered in hair-like sensory tentacles that move in order to perceive sounds, sights, depth, and smells. To Lilith, the hair-like tentacles that "writhed independently, a nest of snakes startled, driven in all directions," evokes images of Medusa (13). She cannot will herself to calm down or move closer to him, and assesses that it is "his alienness, his difference, his literal unearthliness," rather than his appearance, that frightens and repulses her (13). She is shocked by the intensity of the "true xenophobia" Jdahya's otherness inspires in her.

Jdahya slowly, over the course of days, allows Lilith to grow accustomed to his presence, telling her that once she can control her fear of him, he will free her from the room. In the meantime, he fills in the gaps in Lilith's memory and discloses the Oankali's plan for Lilith's future. With the exception of the short intervals of awakenness, Lilith has been held in suspended animation for close to two hundred and fifty years. She, along with all other surviving humans, 
are being held on an Oankali spaceship that is orbiting the damaged earth. While what's left of humanity has been asleep, the Oankali have been repairing the earth's surface for re-habitation. Their work is nearly complete. The Oankalis plan to return the remaining humans to the restored earth, but there is a catch.

The Oankali, a three-sexed (male, female, and ooloi) alien species from a distant star system, describe themselves as "traders" who travel through various solar systems looking for genetically interesting new species to "trade" with. The Oankali are master genetic engineers who seek to interbreed with new species for the purposes of creating Oankali/trade-partner "construct" species designed with the best genetic traits of both groups. The Oankali seek a trade partnership with humans due to their fascination with cancer. Though deadly to humans, the Oankali believe cancer cells have the potential to be manipulated and redirected. Though the Oankali can heal cells, cancer offers the potential to regenerate lost limbs, to live even longer lives, and to possibly even develop "controlled malleability," allowing them to shapeshift to look more like potential trade partners (41). Despite their interest in acquiring cancer's growth abilities, Jdahya says the Oankali were initially hesitant to initiate a trade with humans. The Oankali are both highly drawn to and repulsed by humanity, considering them to be "horror and beauty in rare combination" (153). The Oankali read human DNA as "fatally flawed" by a "mismatched pair of genetic characteristics" (38). Humans are both intelligent and hierarchical. Alone, the Oankali believe either characteristic could have benefitted the species and its survival, but together, the two traits fate humanity to destroy itself. The hierarchical gene is "older and more entrenched," which led to humans putting their newly evolved intelligence to the service of hierarchical drives (39). The Oankali vow to address the contradiction in their Oankali/human 
construct species, allowing nondestructive parts of humanity to survive in a construct species returned to a restored earth.

In addition to thriving by interbreeding with other life forms, incorporating variety into their genetic makeup, the Oankali realize the cyborg fantasy of a life dually embodied and plugged in. Through genetic engineering, the Oankali have learned to manipulate all life forms and have developed the ability to "grow" the machines they rely on. For example, their spaceships are composed of living, organic material that the Oankali can plug into via their sensory tentacles and communicate with. Simply by touch, the Oankali can direct their spaceship to grow walls, raise beds and tables, and produce synthesized food. The Oankali grow similar environments on earth as part of the restoration of the planet, and they genetically alter humans who comply with the trading agreements at will, giving humans access to and control of designated Oankali zones. The Oankali are thus cybernetic organisms that plug into and control their environment, and other bodies, only they manipulate and plug into organic life. What humans regard as science, and often as artificial meddling with the natural, the Oankali perceive as manipulating nature. The Oankali have an organic equivalent to most manmade machines: their stingers produce a lethal poison, making artificial weaponry unnecessary; their sensory tentacles and organs do the work of human surgical tools; and their cognitive abilities, which give them perfect memories and unlimited storage of genetic materials, perfect the work of human computers.

Jdahya informs Lilith that the Oankali have chosen her to be the first human birthmother of the Oankali/human construct species. Further, she is tasked with awakening and training the first groups of humans who will return to earth and repopulate the planet with Oankali/human constructs. Lilith rejects her role from the start and insists that the other human survivors will 
similarly refuse to acquiesce to the Oankali's demands. Jdahya reveals that the Oankali have genetically altered all human survivors' bodies in order to coerce human compliance with to the Oankali agenda; the Oankali have greatly increased human longevity, but they have also sterilized all human survivors. The Oankali will only restore human fertility after humans agree to mate with the Oankali, ensuring that if humanity is to survive in any form, it will be a posthuman, construct existence.

When she is able to tolerate Jadhya's presence, he frees her from the holding room and takes her to stay with his family. There, he assigns her training to his subadult ooloi child, Nikanj. Unbeknownst to Lilith, she has been chosen as Nikanj's future human mate. She discovers that a few humans have been awakened and demands to meet one. The first human man she meets attempts to rape her. As Lilith learns about the Oankali, she is given more freedom to move about the ship and the ability to open select walls. She is also given an eidetic memory. After assisting with Nikanj's metamorphosis into adulthood, she accompanies it to its new mates' home, where she becomes the human female mate to all three Oankali. She is then taken to the training area of the ship for one year, which has been constructed to mimic earth's new ecosystem, and trained to survive in the elements. When her training is complete, she is placed in a large room with eighty sleeping humans. She is given the ability to wake them, and is charged with waking at least forty. According to the Oankali's plan, when the humans have been awakened and told of their new life, they will be transported to the training area to learn survival skills from Lilith. Though Lilith complies with her assigned duties, she maintains a personal agenda to train the humans to "Learn and run!" She understands that resistance while on the ship is futile, but holds out hope that humans will be able to break from the Oankali when sent back to earth. 
As Lilith slowly awakens humans, beginning with a woman, Tate, the humans quickly divide into groups of those who are willing to cooperate with Lilith and those who see her as a traitor or an agent of their captors. Since no one else has seen an Oankali, none of the humans truly believe Lilith's story. Though many accept that the Oankali are aliens, few believe they are on a ship or that so much time has passed. Violence is common among the awakened, including attempted rapes and attempted murders, and several of the awakened men attempt to usurp Lilith's power. The group tends to pair off into male and female sexual partnerships. Lilith takes a man named Joseph as her mate. When the group begins to plot against Lilith, the Oankali, who have been observing, decide to make themselves known. Several ooloi enter the holding room and drug the humans prior to each ooloi selecting a human pair as its future mate. When the drugs wear off, the humans resent the ooloi for compromising their resolve with drugs and many of the men express sentiments of being "taken like a woman" without their will. When taken to the training area to learn survival skills, many of the humans, believing that they are on earth, attempt to flee. One group even convinces Lilith and Joe to flee with them, only to attack Lilith in the night. When she regains consciousness, she discovers that one of the men has killed Joseph. After Joseph's murder, the Oankali decide to send the group to earth, but they keep Lilith on board the ship. When Lilith demands to know why she has been left behind, Nikanj informs her that it has made her pregnant.

Adulthood Rites opens decades later and follows the early life of Akin, Lilith's first construct son. Lilith is now living on earth, in the colony of Lo. Like the Oankali ship, Lo is "grown" by the Oankali and the Oankali can interact with all aspects of the environment. The Oankali have also altered all humans living in Lo, allowing humans to control certain aspects of the environment: raise and open walls; summon synthesized food; raise furniture; etc. Lilith, 
along with other human females who have accepted a trade partnership with the Oankali, has now given birth to many construct children, all female. Several of Lilith's children are already adults.

Not all humans living on earth have accepted the Oankali's trade partnership. The Oankali allow humans to live in separate resister colonies, but all human resisters remain infertile. As a result, resister humans often attempt to steal construct children, especially premetamorphasis children who look more human than Oankali. Akin, the first male construct, looks very much like a human baby; however, as a construct, Akin's mental maturity is more in line with a human teenager's. Akin is kidnapped by male resisters and sold to Tate and Gabriel, two of the first humans Lilith chose to awaken who are now living in Phoenix, a resister colony. The Oankali of Lo, despite knowing where Akin is, decide to leave Akin in Phoenix in order to learn more about the resisters. Akin develops deep bonds with Tate and Gabriel before his parents rescue him. After his rescue, Akin spends his youth wandering between Lo and surrounding resister villages, often having sex with human women and storing as much genetic information as possible from the humans and environments he meets. After going through metamorphosis and becoming an adult, an adult who now looks more like an Oankali male than a human, Akin becomes an advocate for the resisters' cause. As an ambassador for human resisters, Akin is able to negotiate a deal with the Oankali. The Oankali refuse to restore resister's fertility on earth, but they agree to teach Akin how to make Mars habitable and promise to allow human resisters, with their fertility restored, to establish a human-only colony on the desolate planet.

The trilogy closes with Imago, which tells the coming-of-age story of Jodahs, Lilith's construct child and the first construct ooloi. Jodahs realizes the Oankali dream of incorporating 
human cancer cells into a construct species in order to develop shape-shifting abilities. After its metamorphoses, Jodahs's body is able to form itself into an image that its partners find most appealing. Usually, this manifests as Jodahs changing to look more like its desired human partners. Jodahs seems unable to completely control these changes; it somewhat literally becomes the object of its other's desire. In the absence of a desired other, Jodahs's body loses shape and form, and at one point it fears the boundaries of its body will dissolve completely and be incorporated into the earth (or Lo).

Like its brother, Akin, Jodahs wanders. In its travels, it happens upon a resister colony hidden in the mountains of South America. Generations back, one resister woman in this colony became pregnant and gave birth to a son. As the only known fertile resister human on earth, the community separated the mother from the son and reunited them after the son went through puberty. The mother and son bore more children, and the community that Jodahs discovers, generations later, is the result of intense inbreeding. Many of the humans are deformed and disabled, but they are "pure" humans. Jodahs mates with a brother and sister human and, again like Akin, becomes an advocate for the resister colony it has grown to love. The trilogy ends after Jodahs has successfully negotiated an agreement between the Oankali and the resister colony that will allow the resister colony to become the first fully construct generation, designed by a construct ooloi.

\section{Genetic Essentialism}

"I began the story wondering how much of what we do is encouraged, discouraged, or otherwise guided by what we are genetically. This is one of my favorite questions, parent to several of my novels. It can be a dangerous question. All too often, when people ask it, they mean who has the biggest or the best or the most of whatever they see as desirable. Genetics as a board game, or worse, as an excuse for the social Darwinism that swings into popularity every few years. Nasty habit.

And yet the question itself is fascinating. And disease, grim as it is, is one way to explore answers. Genetic disorders in particular may teach us much about who and what we are." -Octavia Butler, Bloodchild 
The complexity of Butler's characters and themes in Xenogenesis has yielded equally complex and contradicting scholarly interpretations. The Oankali are nonviolent, irritatingly patient, rational beings. The Oankali value life above all else. The surviving humans, on the other hand, are reactionary, quick to violence, bigoted, and emotion-driven. In short, Butler's Oankali are easy to like while her humans are frustratingly easy to hate. On the surface, Butler's depiction of humanity seems to prove the Oankali correct—her humans do seem hell-bent on their own extinction. Some writers criticize the trilogy on these grounds. Hoda M. Zaki, for example, concludes that the trilogy depicts human nature as "fundamentally violent" and perpetuates binary thinking that "men are intrinsically more violent than women" (241). Most damningly, Zaki argues that Butler's work advances a belief in "unmediated connections between biology and behavior," resulting in an anti-utopian pessimism that "the human propensity to create the Other can never be transcended" (241). On a related note, Walter Benn Michaels views the trilogy's promotion of a construct species as an unwitting gesture towards colorblind ideology, arguing that the Oankali's trade deal promotes a homogenized posthumanist future that masks, rather than solves, human tendencies toward hierarchical division: "In a thoroughly miscegenated world, everybody would be the same" (659). In Michaels's reading, the Oankali's interbreeding agenda acts as a "technology for the elimination of difference" between human and Oankali (659). To borrow Jessie Stickgold-Sarah's phrasing, “critics thus often struggle with what is seen as a lack of resolution or a kind of fatalism, attempting to find liberation in a text which is deeply, comfortably engaged with the limitations and oppressions of the embodied self" (418). Or perhaps Nancy Jesser's rhetorical question more directly gets to the point: "What kind of feminist is Butler if she holds to a biologically informed notion of female experience?" (37). 
Butler's body of work lends itself to such criticism as her SF often directly engages with one of her "favorite questions": how much of human behavior is genetically determined? Her toughest critics suggest that, in the end, Butler's work too closely aligns with genetic essentialist thinking. The human resisters in Xenogenesis seem to exemplify this tendency. Despite their assertions that they can will themselves to overcome what the Oankali deem a fatal genetic contradiction, and thus survive as an unadulterated species, the human resisters inevitably engage in behaviors that suggest the contrary: resister colonies organize according to pre-war ethnic and national divisions; colonies revert to heteronormative patriarchal structures in which male violence against women is commonplace; and colonies war with each other, vying for land and property. In short, the humans seem to have learned nothing from the nuclear apocalypse that would have resulted in human extinction had the Oankali not intervened. Perhaps the trait that most suggests that humans are fated to self-destruction is their "true xenophobia" that compels most surviving humans to steadfastly reject the Oankali trade deal, preferring human extinction over the thought of blending with the alien Other.

Such critics have a point. Witnessing the humans' consistent abject failures to curb their hierarchical tendencies makes for a frustrating, if not maddening, reading experience. However, I find that the humans' steadfast insistence that neither their potential nor their fate as a species is bound and determined by their genetic makeup, despite all evidence to the contrary, infuses the trilogy with eutopian hope. As readers, we root for the humans. We want the Oankali to give the humans a chance. It is precisely this desire that makes the humans' constant failures so frustrating. Rationally, rooting for these humans is counterintuitive. Yet, there is something compelling about the humans' demand to be recognized as more than a body, more than a decipherable and knowable genetic code. Readers' tendencies to side with the humans could 
easily be explained by what Lilith describes as a "true xenophobia." Perhaps humans, human readers included, simply cannot overcome our genetic contradiction and our visceral fear of the other.

However, I tend to agree more with Sherryl Vint's reading that the trilogy gives voice to late-twentieth-century anxieties about trends in genetic science, allowing readers to "see the assumptions about the body that are informing contests over genetic technology" (59). In other words, the Oankali stand in for contemporary discourses about the human body that are grounded in genetic essentialist assumptions. While the resister humans' behaviors seem to confirm genetic essentialist principals, it is the Oankali who hold and enforce genetic essentialist ideologies. And their solution to the human contradiction unnervingly resonates with a very twentieth-century human trend towards genetic welfare.

Butler's 1987 Dawn, the first installment in the Xenogenesis trilogy, was published just two years after Atwood's The Handmaid's Tale. Perhaps not surprisingly, both authors use their speculative visions to directly respond to social and political trends emerging during Reagan's administration and, significantly, both novels juxtapose biopolitical war with reproductive justice. Whereas Atwood uses her handmaid to criticize Reaganite fetal motherhood iconography, Butler's Dawn was written as a response to Reagan's early campaign statements that a nuclear war with Russia was not only winnable, but a viable option for defeating the spread of the Soviet Empire. Butler was surprised by Reagan's comments, but she was shocked that the US majority elected him as Commander in Chief after expressing his pro-nuclear position. Rather than blame Reagan's administration for the US's cold-war-fueled, ambivalent attitude towards nuclear warfare, she feared the popularity of his nuclear position might be 
symptomatic of an inherent human flaw that bent humanity towards self-destruction (“Interview”).

Butler's fears of an inherent human flaw dovetail with a trend towards genetic essentialism and genetic welfare in the late-twentieth-century in which "genetic information tells the 'truth' about individuals" (Vint "Octavia" 64). Butler began writing Dawn during the early buzz surrounding the Human Genome Project (HGP), an international endeavor to identify and map the genes of the human genome. The discourse surrounding the project suggested that, once identified, sequenced, and mapped, the human genome could be the key to unlocking "what it means to be human" (Vint 63). As Vint notes, HGP enthusiasts often metaphorically described the HGP as a mythic quest for the "Holy Grail," the "bible," the "code of codes," or the "key" "that will allow us to decipher humanity" (63). Vint suggests that such language points to a dangerous marriage between biomedical science and a belief in genetic essentialism, and she warns that such a union threatens to establish a socially constructed biological determinant of "normal" and "abnormal" based in genetic codes. As such,

Genetics threatens to be the most sinister example of the power of a discourse to produce its normalized subjects - both through its representations of what it is to have "normal" genes and through its power to control the materialization of genetic combinations through selective abortion or IVF screening. The Human Genome Project claims to map "what it means to be human," to create a "baseline norm" for humanity, even though there are as many as three million base pairs of difference between individuals. (Vint 63) 
Diverging from other disciplinary mechanisms that normalize already-born subjects, the field of genetics, with the help of ARTs, offers biopolitical systems the ability to pre-screen for genetically "abnormal" humans and prevent them from contaminating the body politic.

Diverging from Atwood, who shirks genetic science and ARTs in her dystopian vision, Butler extrapolates contemporary high-tech biomedical practices and brings genetic engineering and assisted reproduction to the forefront of her post-apocalyptic tale. However, Butler avoids a reactionary anti-science/anti-biotech stance by locking her critical focus on genetic essentialist ideology:

Butler's Xenogenesis novels, while not explicitly concerned with warning us about the medical risks of new genetic technologies, are concerned with warning us about the social and cultural risks of a culture in which genetic information is the "truth" about individuals. Through displacing the genetic science to an alien technology, Butler encourages her readers to see ourselves as the objects acted upon by genetic technology rather than the subjects who choose how to use it. (Vint 64)

From this view, Butler's criticism attacks two fronts simultaneously. On one hand, her human characters force readers to reckon with humanity's legacy of violence and oppression born of hierarchical thinking. On the other hand, her Oankali characters encourage readers to resist the Oankali's genetic essentialist assumption that humanity's ills are an inevitable result of genetic coding. In the end, her trilogy asks readers to reject the human resisters' fear of the other and insistence on genetic purity while also rejecting the Oankali insistence on genetic essentialism. We are not encouraged to root for the humans so that the humans can remain "pure"; in fact, we are not asked to reject the Oankali's trade deal. Rather, we are encouraged to look beneath the 
benevolent surface of Oankali's promises to protect and preserve "life in general" and recognize the systems of power at work in Oankali society. In short, "The Oankali may be genetic essentialists, but Butler's readers are encouraged not to be" (Vint 67).

Genetic essentialism yields policies of genetic welfare that seek biological solutions to social problems. Marque-Luisa Miringoff defines genetic welfare as "the desire to improve the human condition through genetic and reproductive intervention. Its proponents are those who seek to modify the genetic foundation of human life, to bring about a healthier society, with fewer human problems" (6). On the surface, genetic welfare practices appear to be motivated by benevolent desires to make life better for all. In practice, however, genetic welfare programs are just one more way to enact the "nasty habit" of social Darwinistic thinking.

Interestingly, Jessie Stickgold-Sarah connects genetic essentialist discourses with literary dystopias, arguing that the essentialist metaphors used to describe DNA and its powers align with the classical dystopian protagonist's epiphany that his world and life have been predetermined and designed: "when we speak this way about ourselves, we too begin 'unreflectively immersed' in our own conceptions of identity, and then awaken to a new understanding of ourselves that is dependent on a kind of genetic control which, though inside the body, is conceived of as outside the self" (415). Genetic essentialist rhetoric, while promoting hope for the species through genetic engineering and selective breeding, leaves little hope for change for the individual who perceives her fate to be determined by her genetic code. In other words, genetic essentialism does not allow for a view of identity disassociated from genetics, i.e., the body. Though, as Stickgold-Sarah describes, genetic code is viewed as "outside the self," genetic essentialism insists that the individual cannot, through force of will, overcome her genes. Genetic essentialists thus believe that DNA tells the entire story of the person and a 
person can only think or act in accordance with her genetic coding. Such a deterministic view closes off eutopian possibilities of change for both the individual and the species. The Oankali embody such a pessimistic genetic essentialism, as "the Oankali romanticize the body, believing that it inevitably speaks the truth while words and consciously expressed desires can be used to deceive, even to deceive oneself" (Vint 69).

While Butler's trilogy has often been criticized for promoting a dystopian genetic essentialist vision, Stickgold-Sarah and Vint read the novel as ultimately a eutopian expression against genetic welfare sentiments. Stickgold-Sarah sees the trilogy's eutopian potential in its rewriting of genetic determinism as a positive force by Butler's use of genetic engineering and interbreeding to yield her final vision of a posthuman species. In her view, the Oankali are not wrong about the self-destructive potential of the human contradiction. However, the Oankali also represent a new vision of genetic determinism that is able to "dislocate genetic engineering from our limited understanding of it" (423). Genetic engineering, and the DNA-deterministic rhetoric that surrounds it, is concentrated around establishing base norms and eliminating what is considered abnormal. Conversely, the Oankali, who use genetic engineering to create something new by introducing diversity and variety, represent a "reimagination of DNA as malleable, manipulable and accessible," and thus act as a rewriting of genetic determinism in a positive light that allows us to "image a future in which genetic determinism acts to open doorsalthough we may not like what's behind them" (423). The Oankali's rewriting of cancer and its limitless possibilities for growth, sustainability, and life epitomize the transition Sarah-Stickgold discusses, as, in our "limited understanding" of genetic engineering, we endeavor to find ways to eliminate cancer, whereas the Oankali imagine ways to manipulate and use cancer positively. 
The human-Oankali constructs at the novel's end may not fit within genetically constructed definitions of "human" and "normal," but they will survive and overcome humanity's self-destructive tendencies. This survival would not be possible without first understanding genetics and then learning to manipulate and alter genetic codes by introducing diversity. Stickgold-Sarah concedes that, to the surviving humans in the novel who insist on their ability to overcome their genetic contradiction, the loss of their children's human purity to interspecies breeding remains a dystopian conclusion; however, "the utopia is born, as all utopias are, out of the loss of the current generation" (425). For the construct children, who possess the Oankali ability to read and manipulate genes as well as the human inclination to value personal will, the promise of a posthuman, hybrid species is infused with eutopian possibility.

\section{Biopolitical Oankali}

On the surface, the Oankali appear to embody much posthumanist optimism of a cyborgian future in which diversity is a cherished necessity, actively pursued through participatory evolution. Whereas "humans persecute their different ones, yet they need them to give themselves definition and status," the "Oankali seek difference and collect it. They need it to keep themselves from stagnation and overspecialization" (329). The Oankali impulse to

diversify is credited to the "Oankali organelle." Each construct generation is given the organelle, which the Oankali regard as "the essence of ourselves," that allows ooloi to perceive and manipulate DNA and drives the species' genetic impulse to seek out and conduct future trades (40; 41). Jdahya describes the Oankali trading impulse as too powerful to resist: "We must do it. It renews us, enables us to survive as an evolving species instead of specializing ourselves into extinction or stagnation" (40). Though the Oankali deny any hierarchical tendencies in their 
species' genes, they regard themselves as "powerfully acquisitive" in their ability to "acquire new life - seek it, investigate it, manipulate it, sort it, use it” (41). As the trilogy plays out, however, the Oankali compulsion to seek out and acquire genetic variety ends up looking remarkably similar to biopolitical colonialism.

The Oankali invoke the rhetoric of genetic welfare as a justification for their coercive trade partnership with humanity. To borrow Aparajita Nanda's prhasing, "the Oankali adroitly camouflage their colonizing intent, enforcing restrictive reproductive rights on humans, in a rhetoric of altruistic salvation" (775). Resonating with $20^{\text {th }}$-century eugenics programs, the Oankali's motives are dressed in the discourse of benevolence and social progress. Most notably, the Oankali justify their sterilization of all humans who refuse their trade agreement by citing the human genetic contradiction. The Oankali, who claim to be intrinsically (i.e., genetically) opposed to taking life, believe that allowing humans to reproduce freely, only to eventually "oneup" themselves into extinction, would be a "profoundly immoral, antilife thing" (475). In other words, the Oankali justify their complete control of human reproduction on moral grounds, citing their desire to safeguard the health of the human species. However, while the Oankali do appear to genuinely act in the best interests of both species, their rule over humans is nothing short of ruthlessly authoritarian. The Oankali do save what is left of humanity rather than letting the species fall to extinction, and they do offer a viable, posthuman solution to the human species' tendency toward hierarchical organization. However, while not violent, the Oankali are coercive, powerful, and unyielding. Humans are given little choice in the "trade agreement," and are awakened on the Oankali ship to a life without political or bodily agency.

Despite the Oankali's stated intentions to heal and help the survivors' bodies, humans perceive these interventions as violations, changes to their bodies made without their knowledge 
or consent. When Jdahya informs Lilith that the new scar on her abdomen resulted from a surgical procedure to remove a malignant tumor from her stomach, a tumor that would have eventually killed her, she responds with horror rather than gratitude and immediately demands to know what else has been done to her. Jdahya responds with an incomplete answer: "strengthened your immune system, increased your resistance to disease in general" (32). She does not yet know of the changes to her fertility, yet she immediately thinks, "This was one more thing they had done to her body without her consent and supposedly for her own good. 'We used to treat animals that way,' she muttered bitterly"' (33). Lilith's analogy introduces the trilogy's central conflict between Oankali and humans. Nanda describes this conflict as Butler making "a major intervention into the discourse of postcoloniality by suggesting a third meaning that is neither colonialism nor "not colonialism"” (773-4). By depicting a "bloodless colonization" of humans, Butler is able to better articulate that even when colonizers' motives are genuine and mutually beneficial, "the colonial situation itself" is "intolerable from the standpoint of human solidarity and individual freedom" (774). The Oankalis' frequent intrusions into human bodies without humans' knowledge or consent, regardless of the Oankli's intentions or the possible physical benefits the humans may reap from the intrusions, results in humans' perceptions of the new world order as decidedly dystopian.

As the plot unfolds, more inconsistencies between the Oankali's stated motives and their treatment of humans bubble to the surface. As Donna Haraway points out, the Oankali do not have to interbreed with humans in order to acquire human genetic codes, or even to engineer a construct species: "hierarchy is not power's only shape—for aliens or humans. The Oankali make 'prints' of all their refugees, and they can print out replicas of the humans from these mental-organic-technical images" ("Biopolitics" 228). In fact, the Oankali made prints of every 
rescued human while the humans slept in suspended animation, "But the Oankali want more from humanity; they want a full trade, which will require the intimacies of sexual mingling and embodied pregnancy in a shared colonial venture in, of all places, the Amazon valley" (Haraway "Biopolitics" 228). Haraway points to the uncanny resemblance of Lilith's 250 years in captivity, held in the belly of a ship, to the Middle Passage, drawing deep parallels between the horrors that brought Lilith's ancestors to North America and her capture by the Oankali. In both instances, "the terms of survival were premised on an unfree 'gene trade' that permanently altered the meanings of self and other for all the 'partners' in the exchange" (228). Regardless of the Oankali's sincere belief that allowing humans to continue to procreate would "be like breeding intelligent beings for the sole purpose of having them kill one another" (501), their actions smack of the cruel practices of the North American slave trade, chattel slavery, and the condition of the mother. The Oankali are not satisfied with making copies of humans in order to engineer more compliant humans and/or an Oankali/human construct species; they instead demand that surviving humans, who have already lived through the catastrophe of nuclear war and the resulting annihilation of their home planet, surrender the only two things they have left to givetheir bodies and their consent. And the Oankali demonstrate, over and over, that they are willing to coerce consent by any means necessary.

While Lilith has known of her assigned task, to give birth to a hybrid species, since her final reawakening aboard the ship, Nikanj promises not to impregnate her until she is ready, until she asks. However, Nikanj realizes that Lilith will never verbally ask, and so it impregnates her when it believes her body has told it she is ready. After Lilith hears of her pregnancy, she protests against it, claiming repeatedly that it "won't be human," "It will be a thing. A monster" (246-7). Nikanj counters her protestations by claiming, "you are ready to be her mother. You 
could never have said so... Nothing about you but your words reject this child" (247). Whereas Nikanj limits Lilith's subjectivity to her body, which has expressed its desire to bear a construct child, Lilith considers her words, as expressions of her will, as central to her personhood. Nikanj considers Lilith's verbal rejections of the child to be expressions of the human "deadly habit" of lying to themselves by contradicting their genetic and bodily inclinations; however, Lilith insists that mind and body together "express the full extent of her subjectivity" (Vint 69). Years later, after Lilith has born several construct children, her human mate Tino asks her if Nikanj had been correct about her body wanting a child. Her reply stresses the importance of viewing subjectivity and agency from a mind+body perspective: "Yes...Oh, yes. But if I had the strength not to ask, it should have had the strength to leave me alone" (274).

Though they are driven by opposite compulsions, the Oankali and the humans are both governed by nationalistic impulses to protect the health of their body politics. In this way, Butler's trilogy engages with much skepticism within biopolitical discourses of the ability of western genetic and medical discourses to divorce themselves from legacies of hierarchal stratification (Mills; Nilsson and Wallenstein). Of the two species, the Oankali give credence to such cynicism in their absolute adherence to genetic essentialism; therefore, they more fully stand in for sociobological trends informing genetic science in the late twentieth century. According to the Oankali, all species, including Oankali and humanity, are wholly driven and determined by their biological makeup. Whereas the humans maintain that they have the ability - the willpower - to overcome their genetic contradiction now that they are aware of it, the Oankali insist that "Human purpose isn't what you say it is or what I say it is. It's what your biology says it is - what your genes say it is" (501). Akin explains that the Oankali knowledge of DNA is unlike any knowledge humans have: "You can't see and read genetic structure the way 
they do. It isn't like reading words on a page. They feel it and know it. They...There's no English word for what they do. To say they know is completely inadequate" (502). Contrasting Bacigalupi's generippers, who represent the humanist privileging of the mind over the body that lurks beneath much posthumanist enthusiasm, Butler's Oankali represent the equally dangerous legacy of genetic essentialism and eugenic impulses that permeate twentieth-century genetic discourses. In Vint's words, “Just as Butler cautions us against accepting the Oankali's genetic essentialism, she also warns us against romanticizing the body as a pure expression of nature and truth" (70). In short, Butler's Oankali warn against a too embodied posthumanism, or a posthumanism too heavily invested in sociobiology, while her humans' repeated follies caution against a more disembodied stance that views the mind capable of fully overcoming the body.

I suggest a reading of the Oankali as a biopower, an analysis that closely aligns with writers who view the trilogy as a an allegory of colonialism (Goss and Riquelme; Nanda; Haraway "Biopolitics" ). Biopolitical agendas have historically been put to the service of colonial ambitions, and vice versa, as modern colonialism and biopower emerged concurrently. Most apparent in an Oankali/biopower analogy is the Oankali's complete control of human life by controlling reproduction and extending human longevity. As noted by Akin, the first male human-born construct, "You controlled both animals and people by controlling their reproduction — controlling it absolutely" (447). In their quest to control life itself, the superrace Oankali envision drawing all surviving humans within the boundaries of a normalized Oankali body politic. The Oankali/human trade deal equates human fertility with Oankali citizenship and political agency; humans who acquiesce to the trade partnership are granted a subrace status within the Oankali body politic, or a contested political existence, whereas humans who resist the interbreeding partnership are fated to a sterile, bare-life existence. 
The human impulse toward hierarchy and the Oankali impulse toward diversity result in the two species' conflicting eutopian dreams. Contrasting Reagan's call to return to a brighter future by recreating yesterday, an impulse mimicked in the trilogy by the resister colonies who attempt to recreate "prewar" life, the Oankali insist that a people group can only progress to a better future by constantly evolving and never looking back. Jdahya, Lilith's first Oankali contact, explains that what ruins were left on earth after the nuclear war are being destroyed by the Oankali to discourage the future human inhabitants from attempting to recreate their old ways of life: "you'll begin again. We'll put you in areas that are clean of radioactivity and history. You will become something other than you were" (emphasis mine 34). In other words, the Oankali appear to promote a vision of the future that directly contradicts Reagan's nostalgic nationalism and its insistence on homogeneity. The conflict between eutopian visions produces an irresolvable conflict between the two species, as the Oankali perceive subsuming human existence within the Oankali body politic as the only possibility for the continuation of the human species, whereas the humans, who define humanity within bound parameters, view hybridity as extinction.

Though the two species are presented as opposites, Butler uses the Oankali to mirror humanity and its tendency toward binary thinking. The Oankali and humanity appear to operate under opposite compulsions, as "human beings fear difference" and "Oankali crave difference," however, both species' responses to difference stem from quasi-nationalistic drives to survive and thrive as a distinct people group, often at the expense of other groups (329). Despite the Oankali's claims to be a genetically nonhierarchical species, their genetic compulsion to "trade" with other species in order to play the architects of their own evolution derives from a desire to secure the Oankali's future survival, a survival that depends on the suppression and elimination 
of other species and planets. In spite of the Oankali's insistence that humanity will live on after the trade, Akin contests that humanity will be subsumed under the Oankali rather than representing an equal part of the construct species: "But we will be Oankali. They will only be...something we consumed" (443). Akin's pronouns testify to this truth, as he privileges the Oankali half of himself_-"we"—over his consumed humanity—"they."

The full extent of Oankali consumption during trade partnerships is obscured until Akin's reflections in Adulthood Rites, but hints of the true Oankali agenda appear early in Dawn during Lilith's first conversations with her Oankali jailor. When Lilith asks Jdahya if the Oankali will ever return to their home planet, he offers the enigmatic response, "Go back?...No, Lilith, that's the one direction that's closed to us" (36). We learn through Akin that the Oankali grow new ships from the surfaces of the planets they colonize, eventually launching these spaceships toward the stars in search of new species to trade with. Unbeknownst to the human survivors, the Oankali are already at work growing ships on Earth (Lo is a future ship), which will one day launch, leaving the Earth "small, cold, and as lifeless as the moon" (365). The Oankali cannot return to their homeworld, or to any world where they've traded, as the price of engendering a new species is the consumption of the trade-partner species and its world. Whereas humanity is depicted as fatally handicapped by its anti-utopian inability to conceive of a future different/better than the past, the Oankali are equally anti-utopian, blind to the possibility of incorporating the past into the development of a better world. Further, despite extolling the virtues and necessity of diversity, the Oankali control trade, design construct species, and subsume trade-partner species beneath the homogenizing label of "Oankali."

Despite their claimed benevolence, the Oankali enact ruthless biopolitical programs, and their alienness allows them to be mapped onto, and read as an allegory of, a biopolitical system 
marked by a legacy of eugenics and genetic essentialism. Consistent with Foucault's descriptions of biopolitical systems, the Oankali have taken control of all life processes, including birth rates, lifespans, and death. Without the human survivors' knowledge or consent, the Oankali have addressed genetic diseases, healed illness and injuries, unlocked genetic codes to radically increase human longevity, and sterilized all human survivors prior to placing them in suspended animation for two and a half centuries. The Oankali place themselves as the superrace in a superrace/subrace binary, and, to borrow Agamben's phrasing, assign human resisters to a barelife existence that includes infertility. The humans are awakened as captives on a spaceship, completely dependent upon the Oankali for survival, and rendered unable to reproduce without the Oankali's assistance. The Oankali justify the humans' sterility by appealing to the human genetic contradiction, insisting that the Oankali are controlling human reproduction for the health and survival of the species. This sentiment is best captured by Jodahs as, "The Oankali believe...the Oankali know to the bone that it's wrong to help the Human species regenerate unchanged because it will destroy itself again. To them it's like deliberately causing the conception of a child who is so defective that it must die in infancy" (532). Butler's Oankali echo the language of US eugenics programs, both "positive" and "negative," that quietly operated through the 1970 s by pressuring upper- and middle-class white women to reproduce while discouraging, and even sterilizing, nonwhite, poor, and "feebleminded" women without their consent. Claiming to act in the best interest of the (white) race or nation, nationalistic eugenics programs infringe on the individual's reproductive agency in order to increase the chances that new, fetal citizens will adhere to constructed definitions of genetic normality. In spite of their alienness, the Oankali's motives and power structures should ring all too familiar with Butler's readers. It should come as no surprise, then, that the immediate results of the Oankali's 
biopolitical co-option of human reproduction are the production of biopolitical cyborgs: mothersoldiers, soldier-cyborgs, and bare-life cyborgs.

\section{Soldier-cyborgs, Mother-soldiers, and Bare-life Cyborgs}

\section{The Oankali}

Despite their intelligence and power, the Oankali function as biopolitical soldier-cyborg figures. Even more completely than Lowry's Community citizens, the Oankali, and all materials and lifeforms incorporated into Oankali existence, are deliberately constructed to fulfill particular purposes. Akin's observation of a tilo, a common service animal used aboard Oankali ships, best captures the extent to which Oankali genetic engineering effectively creates beings without the willpower, or even the desire, to challenge the Oankali's agenda: "The tilo had been fashioned from the combined genes of several animals. Humans put animals in cages or tied them up to keep them from straying. Oankali simply bred animals who did not want to stray and who enjoyed doing what they were intended to do" (446). Nolan Belk notes that the Oankali are not exempt from the oolois' designed compliance mode of creation: "every being is carefully designed by the ooloi gender to provide the proper adult organism, 'to control the direction of life' for all life including the Oankali" (377). To aid in this designed compliance, the ooloi design all lifeforms, from spaceships to Oankali citizens, to receive intense sensory/sexual pleasures from fulfilling their designed purposes. As a result, all Oankali lifeforms become somewhat addicted to compliance.

Significantly, human actions often confound the Oankali's genetic-essentialist assumptions about humanity. The Oankali consistently underestimate human willpower. This is most evident in the surprising longevity of the resister colonies. While still aboard the ship, all 
recently awakened human male-female partners are coerced into "mating" through an ooloi. According to Oankali genetic knowledge, the bonding process between humans and their ooloi should be so strong and so pleasurable that humans should find ooloi/human intimacy literally irresistible. In Lilith's experience, bonding through an ooloi provides indescribable sexual pleasure for all partners. Further, after human partners bond via an ooloi, the two humans can no longer tolerate unmediated physical contact with each other. Additionally, human pairs bonded with an ooloi should form a physical, emotional, and psychological dependency on their ooloi and should not be able to tolerate long absences from their ooloi. This is the primary reason why the Oankali allow humans, once returned to earth, to flee the Oankali and form resister colonies. The humans should simply not be able to tolerate life without the Oankali for long. Sterilizing the humans should also increase the likelihood of human acceptance of the trade deal.

However, despite the intense physical and emotional pain human resisters suffer, and thanks to the Oankali's "gift" of increased longevity, human resister groups thrive for decades following their return to earth. Human sexual partners even regain the ability to touch each other unmediated following long absences from their ooloi. Their ooloi, conversely, continue to physically suffer from the separation. For Vint, the eutopian hope of the trilogy is found in the humans' abilities to resist consenting to the Oankali trade agenda. Though the humans do not seem to be able to curb their self-destructive heirarhcal tendencies, their ability to will themselves to resist the Oankali, like Lilith's ability to refuse to ask for a child that her body wants, suggests that the body alone does not determine subjectivity ("Octavia").

Though the trilogy focuses on the fate of the humans, and more explicitly questions what a blending of the species will cost humanity, the human ability to resist Oankali coercion tactics, despite humans' genetic makeup, provides a eutopian glimmer for the future of the Oankali 
species. Like Lowry's Jonas, the Oankali unreflectively acquiesce to the roles they are literally designed and created to fulfill. They do not question the Oankali dogma that genetics tell the entire truth of a life form. Their belief in genetic essentialism is profoundly anti-utopian, as they fundamentally reject any possibility that life forms can change their fate by envisioning a different future. The humans' ability to resist their bodies' compulsions to accept an Oankali partnership defies Oankali genetic essentialist dogma and opens the possibility that a merger of human and Oankali may yield surprising results. Perhaps the new construct species will carry the humans' insistence on individual choice and agency, resulting in a posthuman construct that maintains the human ability to think and act beyond its genetic coding, that believes in its ability to choose and to resist.

\section{Lilith}

Over the past few decades, various feminist writers and artists have reclaimed the "Lilith" moniker. She has come to symbolize the plight of women within patriarchal systems who contest notions of biological inferiority and demand political and social equality. She claims her mind and her body as her own and acts accordingly. As such, Lilith has become a useful metonym of a strong, defiant, and unapologetically sexual female figure. The feminist Lilith abandons Adam in the garden and chooses instead to lie with demons. Her licentiousness and her monstrous brood challenge heteronormative family structures and open potentials for different conceptions of family and of self. Lilith disrupts, rejects, and sidesteps the edenic origin story and offers a different genesis. Her children are born of hybridity and species adulteration. This Lilith has the power to engender a new, more eutopian world for women.

While this Lilith provides an empowering image for feminist platforms, this recasting from ancient Jewish lore requires a few significant elisions. Lilith does demand recognition by 
Adam and by God of her intrinsic equality with Adam. Lilith does flee the garden and refuse to accept an identity contingent upon her union with Adam. And Lilith does bear hybrid children. But her story doesn't end with her rebellion. God doesn't leave her to her own devices. God's angels relentlessly pursue and punish her, murdering 100 of her monstrous children per day. She is an outcast, relegated to the night as a figure of terror and fated to live in desert ruins. She is blamed for SIDS, miscarriages, and women dying in childbirth. Jewish women wore amulets to protect themselves from her wrath. Yes, she makes autonomous choices and refuses to accept a subservient position, but she pays for her choices with the blood of her monstrous brood.

Butler's Lilith invokes the latter, more troubling image of her namesake. Butler's Lilith does represent the possibility of a new origin story, one less bound in dualisms and "imperative[s] to recreate the sacred image of the same" (Haraway "Biopolitics" 226). As Haraway notes, the global catastrophe of nuclear war and the humans' subsequent capture (and sterilization) by aliens has irreparably severed the remaining humans from their edenic origin stories. Butler's Lilith does stand in the ruins of humanity's edenic fate —of their apocalyptic return to the dust from which they came — and promises to save humanity by rewriting their origin story. But, as Haraway makes clear, this will be a messy, painful, and "ironic" salvation. It will not "liberate" Lilith, and it will cost humanity its "sacred image of the same":

At the end of Dawn, Butler has Lilith—whose name recalls her original unfaithful double, the repudiated wife of Adam — pregnant with the child of five progenitors, who come from two species, at least three genders, two sexes, and an indeterminate number of races. Preoccupied with marked bodies, Butler writes not of Cain or Ham, but of Lilith, the woman of colour whose confrontations with the terms of selfhood, survival, and reproduction in the face of repeated ultimate 
catastrophe presage an ironic salvation history, with a salutary twist on the promise of a woman who will crush the head of the serpent. Butler's salvation history is not utopian, but remains deeply furrowed by the contradictions and questions of power within all communication. Therefore, her narrative has the possibility of figuring something other than the Second Coming of the sacred image. Some other order of difference might be possible in Xenogenesis — and in immunology. ("Biopolitics” 227)

Butler's Lilith may spawn children capable of making a better, more equitable world, but her story is not a story of personal liberation, or even of successful resistance. Lilith's story is the story of a biopolitical mother-soldier, valued by the Oankali for the future construct citizens she represents and despised by the humans, and by herself, for her fated part in "finish[ing] what the war began" (42). Though she fights for personal agency throughout the trilogy, and wins a few small, ultimately inconsequential victories that make her life among the Oankali more tolerable, from the moment the Oankali choose Lilith as the mother of the new species, her fate is sealed.

The trilogy's opening scene is steeped in fetal motherhood iconography. Part I of Dawn is titled "Womb." Chapter one begins with an image of rebirth as Lilith again awakens from suspended animation. She wakes naked, "gasping," her "heart beat too fast, too loud. She curled around it, fetal, helpless" (5). The scene is filled with the circular language of repetition as Lilith experiences the memories of countless previous awakenings while she again becomes "reconciled to reanimation" (5). Her life at present operates in a closed loop of reanimation, life, and suspended animation in which awakening to life again has become "the ultimate disappointment" (5). Prior to revealing the circumstances of Lilith's endless awakenings, Butler renders the woman the Oankali have chosen to be the mother of a new species as helplessly fetal, 
lacking any agency over her body and life processes. This first image of Lilith, which foreshadows her forced Oankali/human pregnancy at the novel's close, resonates with Lauren Berlant's concept of fetal motherhood in which the mother is politically subsumed beneath the future children she may bear in a system that privileges the fetus as more "national" than the mother. To the Oankali, Lilith represents the matriarch of the future as their chosen mother of the first Oankali/human constructs. The Oankali chose Lilith without her knowledge or consent and value her based on her reproductive abilities and maternal instincts.

As a mother-soldier, Lilith's story parallels Atwood's Offred's in significant ways. Primarily, both are forced to sacrifice their own political, bodily, and reproductive agency for the collective's future - a future that does not include them. As Sarah-Stickgold points out, for Lilith, her world is, and will forever be, dystopian. The Oankali realize this, explaining, "Your children will know us, Lilith. You never will" (112). Though her Oankali mates care for her and provide her immense sexual pleasure, they are brutally honest with Lilith that she will never be completely at peace with her forced compliance to their demands. Further, like Offred, Lilith is despised by the humans she has been charged to "save." Both powers that be, the Gileadeans and the Oankali, position Offred and Lilith as the surrogate savior-mothers of the race. For both, the position comes with open hostility from their communities. Whereas Offred is despised for her participation in the desecration of the marriage bed, Lilith is viewed as a traitor to her kind and as somewhat subhuman, the mother of monsters.

Contrasting sharply with Gileadean rule, when Lilith reflects on how the Oankali have drawn her into their scheme, she marvels that "they had done it all so softly, without brutality, and with patience and gentleness so corrosive of any resolve on her part" (67). Though the Oankali do not lie, they withhold information regularly and use all interactions with humans to 
further their trade agenda. As Nikanj's ooloi parent explains to Lilith early on, “we know you, Lilith. And, within reason, we want you to know us" (emphasis mine 50). The humans are continuously fed half-truths designed to slowly discipline them into the Oankali structure. For instance, the Oankali do not fully explain the seductive powers of ooloi until after Oankali/human mating takes place. Similarly, they fail to disclose the knowledge that once two humans mate through an ooloi, they can no longer stand to touch one another without mediating their contact through their ooloi. Without the humans' knowledge, and thus without their consent, the Oankali literally bind the surviving humans emotionally and sexually to the Oankali species. Nikanj, who has been bred to work with humans and disagrees with its ooloi parent on how human compliance should be achieved, expresses its frustrations to Lilith: "There's something wrong with doing it that way—surprising people. It's...treating them as though they aren't people, as though they aren't intelligent. ...Ooan says humans - any new trade partner species - can't be treated the way we must treat each other. It's right up to a point. I think it goes too far. ...We should be able to find ways through most of our differences" $(79 ; 82)$. Lilith, who is now fully aware of her sterility and more aware of the full Oankali plan for humanity, replies, “'Coercion,' she said bitterly. 'That's the way you've found"'(82).

Lilith does find ways to make peace with her status as a mother-soldier. She maintains human practices, like gardening, which also, troublingly, representing her human compulsion to return to an edenic wholeness and unity. She also loves her many children and forges deep, complicated bonds with all of her partners, both Oankali and human. She eventually accepts that she will never be able to resolve her desire for agency over her body with her growing belief that the Oankali may be right about the human genetic contradiction. Though she maintains that 
humans should be given a second chance, she also teaches her hybrid children to privilege their Oankali tendencies. When Akin is young, Lilith tells him,

Human beings fear difference... Oankali crave difference. Humans persecute their different ones, yet they need them to give themselves definition and status.

Oankali seek difference and collect it. They need it to keep themselves from stagnation and overspecialization...You'll probably find both tendencies surfacing in your own behavior... When you feel a conflict, try to go the Oankali way. Embrace difference. (329)

Lilith accepts that humans are flawed, maybe fatally, but she is never able to fully accept the Oankali's coercion of her mind and body. The "ironic salvation" Lilith represents is not her own; it is the glimmers of eutopian hope her children cast for both flawed species.

\section{Akin}

Life on earth is no more eutopian for Lilith's male and female construct children than it is for herself. Male and female construct children are border dwellers, liminal beings who cross between and walk among human and Oankali groups, but they do not fully belong to either. We learn of life as a construct through the story of Akin, the first human-born male construct child. Though the Oankali love and accept construct children, Akin fully understands that he is a precisely designed experiment, planned and created by his ooloi parent, Nikanj. Nikanj designed Akin to look very much human as a baby in order to make it easier for Lilith to love and accept her child. Yet, Akin's sensory organs and intelligence are very much Oankali. His hybrid, liminal status renders him vulnerable and susceptible to human abuse. Akin is kidnapped by a group of 
roaming resister men precisely because he looks so human. The men believe they can sell him for a high price within a resister village.

Akin is terrified of his captors. He tries to act like a human baby by hiding his abilities to walk and talk. He knows that his Oankali family is capable of finding him quickly and rescuing him, yet they don't come. After Tate and Gabe buy Akin, he begins to realize that the Oankali have left him in the resister village intentionally. This will come at great cost to him and his closest sibling. Oankali male and female siblings share a unique bond, one that develops into a sexual partnership after metamorphosis. Oankali bonding includes a male and female sibling pair and an ooloi from another family, a "treasured stranger." Akin's kidnapping results in his separation from his closest sibling, and both he and his sibling suffer physically and emotionally throughout their adolescent lives because of the separation. Akin realizes that his value as an informant for the Oankali supersedes the Oankali's concern for his safety or his happiness. The Oankali hope that Akin can learn of a way to persuade the resisters finally accept a trade partnership, and Akin quickly assesses that his, and his sibling's, personal wellbeing has been displaced by the Oankali's trade agenda.

Resister-human feelings towards construct children are equally complicated. Human resisters' desire for children has given rise to a thriving black market of stolen construct children; however, resister humans also abhor the alien characteristics of construct children and tend to reject their stolen children after metamorphosis. These tensions are most obvious when a pair of stolen siblings is sold to a human resister couple in Phoenix, the resister colony where Akin is also being held captive. The siblings' head sensory tentacles disgust a few resister women. The women begin to solicit support from other Phoenix citizens to cut off the siblings' sensory tentacles, a procedure that would cause the children indescribable physical pain. Akin tries to 
explain to the siblings why the humans want constructs to look more like them. Their conversation reveals the outsider status that Akin and his friends' hybridity relegate them to: "There won't be any more of them," he said, trying to project the sensations of aloneness and fear he believed the Humans felt. "Their kind is all they’ve ever known or been, and now there won't be any more. They try to make us like them, but we won't ever be really like them, and they know it."...

"We are them! And we are the Oankali. You know. If they could perceive, they would know!"

"If they could perceive, they would be us. They can't and they aren't. We're the best of what they are and the best of what the Oankali are. But because of us, they won't exist anymore" (377).

The pronouns used by the constructs further reveal their status as outsiders. The siblings identify as part human, "we are them!," yet Akin counters this identification with "if they," and instead reserves the "we" pronoun for constructs, neither human nor Oankali.

Male and female construct children function as biopolitical bare-life-cyborgs. Like soldier-cyborgs, they are designed to fulfill specific biopolitical purposes; however, they are denied full inclusion into the body politic. The non-construct Oankali value the lives of construct children, but they also understand that the construct children are prototypes of an experiment that the Oankali are willing to abandon if the trade goes badly. In other words, the Oankali, as a whole, hold constructs at a distance, valuing the health of the "pure" Oankali body politic over the wellbeing of individual constructs. Likewise, human resisters refuse to include construct children into their human body politic. Construct children are forbidden commodities and second-rate stand-ins for genetically "pure" human children. 
Akin's liminality is represented by his wandering. ${ }^{42}$ After he is rescued from Phoenix, he chooses a nomadic life, roaming from Lo to nearby resister colonies. As he grows and learns, he finds a purpose for his outsider status. His time at Phoenix planted the seed for his eventual life's work. When the kidnapped siblings at Phoenix repeat the Oankali creed that humans, if left alone, would inevitably find another way to destroy themselves, Akin counters: "Perhaps...I was taught that, too. And I can see the conflict in their genes - the new intelligence put at the service of an ancient hierarchical tendencies. But...they didn't have to destroy themselves. They certainly don't have to do it again" (378). Akin has begun to see that knowledge of genes doesn't tell the true story of human potential. When one of the siblings protests Akin's suppositions, he realizes that "she had not been among resister Humans long enough to begin to see them as a truly separate people" (378). This realization sparks a sudden and intense conviction in Akin that the human resisters must be given another chance to survive on their own terms. When the Oankali initiate a trade with a new species, a group of Oankali, the Akjai, go on as before, unchanged. This practice ensures that the Oankali live on in an older form if a new trade goes badly. Akin understands the possibilities for a better future that the Oankali/human trade opens, but his time with the resister colonies causes him to reconsider the Oankali assumption that all humans must accept the trade if they want to bear children: "He said with intensity, with utter certainty, 'There should be a Human Akjai! There should be Humans who don't change or dieHumans to go on if the Dinso and Toaht unions fail" (378).

\footnotetext{
42 Vint notes that Butler's trilogy perpetuates conservative norms at times. Lilith's bonds with her children rely on unchallenged notions of women as "natural" parents and caregivers. This is contrasted by Akin's intrinsic tendency to wander, a trait that the Oankali attribute to a male human genetic predisposition to seek multiple sexual partners (73-4). Similarly, Haraway notes that, despite the five-parent arrangement required to create construct children, "Heterosexuality remains unquestioned, if more complexly mediated. The different social subjects, the different genders that could emerge from another embodiment of resistance to compulsory heterosexual reproductive politics, do not inhabit this Dawn" ("Biopolitics" 229).
} 
Akin's bare-life-cyborg status allows him to view both species from a distance. He is able to do what no other human or Oankali has yet been able to do- - hold both Human and Oankali vantage points at once. He learns to wield his outsider status to influence both groups, acting as an ambassador for humans among the Oankali and vice versa. Akin exploits his outsider status, changing his pronoun usage depending on his audience. When speaking with Oankali, he refers to humans as "they"; when speaking to humans, he reserves the othering "they" for the Oankali. He accepts that he is both and neither, and accepts his permanent outsider status. Though he isn't able to resolve the two species' differences, he is able to relay the humans' message to the Oankali in a way that the humans could not. Akin is unable to convince the Oankali to restore resister humans' fertility on earth, but he manages to secure permission from the Oankali to make the surface of Mars habitable for humans and take resisters, with their fertility restored, to colonize Mars. Once he has convinced the Oankali to allow him to help resisters colonize Mars, he, "for the first time...looked forward to wandering" (477). Like his mother Lilith, Akin's story is filled with fear, loneliness, and frustration, as he is filled with irresolvable internal contradictions. He is ultimately able to leverage his cyborgian nature to challenge Oankali totalitarian rule in a way that Lilith never is; however, the eutopian glimmers in his story gesture toward a better future for resister humans, not for Akin himself. He is fated to wander between Mars and earth, between humans and Oankali, between shifting versions of "us" and "them."

\section{Lilith's-Children}

The first word of the final novel, Imago, is "I." This stylistic departure from the thirdperson narration of Dawn and Imago signals a fundamental shift in biopolitical cyborg iconography. Before we are told Jodahs's name, before the narrative discloses that Jodahs is the 
first construct ooloi, the "I" suggests that this character is afforded a level of editorial control of its life denied to Lilith and Akin. Jodahs writes its own story.

Jodahs is also quick to tell us that its creation was a mistake. Nikanj did not intend to create an ooloi construct, at least not yet. The Oankali had not planned to create any construct ooloi during this generation of gene trade. Jodahs was intended to be male. Even male constructs were considered risky, as Jodahs tells us, "Human-born males were still considered experimental and potentially dangerous. A few males from other towns had been sterilized and exiled to the ship. Nobody was ready for a construct ooloi. Certainly nobody was ready for a Human-born construct ooloi. Could there be a more potentially deadly being?" (537). In any gene trade, the Oankali are slow to create ooloi constructs because of the ooloi organelle that allows them to create and design life. Once construct oolois are made, the future design of the construct species is in their hands. Oankali/human construct ooloi's ability to create and manipulate life promises to be even more potent, as the construct oolois will be able to wield the power of cancer.

The Oankali's hesitancy to create construct ooloi is not unfounded, as Jodahs's blunders quickly prove. Jodahs is powerful beyond even what the Oankali thought possible, and it struggles to control its abilities. Its body works without the knowledge or consent of its mind, and the slightest touch from Jodahs often alters the recipient's genes in unpredictable and dangerous ways. Jodahs causes the furniture, walls, and floors of Lo to "turn yellow" and develop "swellings. Rough, diseased patches appeared on it. Its odor changed, became foul. Parts of it sloughed off. Sometimes it developed deep, open sores" (554). However, Jodahs's potential to harm humans poses the greater threat. One careless touch could cause mutations, glandular problems, tumors, and “diseases they don't have names for" (552). Moreover, as a human-born construct, Jodahs will crave human contact to such a degree that it will not be able to resist 
"tasting" nearby humans. The ooloi sex go through two metamorphoses. Jodahs's abilities to destroy life in one touch manifest during its first metamorphosis. Its powers will strengthen and it will develop procreative abilities during its second metamorphosis.

Initially, Jodahs is relegated to a bare-life status subordinate to all other Oankali and human life forms. Jodahs is feared as the ultimate threat to the health of both body politics. Symbolically, it embodies the perils of posthuman projects. Its potentials to craft a better future are overshadowed by the immediate threat it poses to life in general. It is the unknowable, and unpredictable, other. The Oankali react to Jodahs's accidental creation with panic and suspicion, fearing both Jodahs's abilities and that its creation will tempt other ooloi on earth to create more construct ooloi. Ooloi deeply desire ooloi children and feel incomplete until creating ooloi progeny. Ooloi who agree to participate in the first generation of a gene trade do so knowing that it means forestalling this personal gratification indefinitely. The Oankali fear that Jodahs's accidental creation will inspire jealousy in other earthbound ooloi (Jacobs 107). The Oankali request that Jodahs seek exile on the ship still orbiting earth; however, Nikanj, Lilith, Tino, and Jodah's male and female Oankali parents instead choose exile from Lo on earth. While in exile, Nikanj attempts to train Jodahs to control its abilities. During the group's wanderings, Jodahs's younger sibling, Aaor, slips into metamorphosis. It is immediately clear that Aaor, who was designed to be female, designed to be Jodahs's sibling mate, will also become an ooloi.

Exile proves to be intolerable for Jodahs. Separated from the company it craves the most — unmated humans — its body struggles to maintain a form that resembles either Oankali or human. Three days into exile, Jodahs's fingers and toes become webbed. Its hair soon falls out and its skin color changes to a gray-green. However, when the exiled group happens upon an injured male human, and Nikanj allows Jodahs to heal and sleep next to the man, Jodahs 
awakens appearing to be "a young woman— too thin, perhaps, but very lovely" (598). Jodahs realizes that its body will transform to please the object of Jodahs's desire. It will soon learn that, in long absences of desired contact, its body will simply refuse to take a particular form or shape. As Vint notes, "The construct ooloi seemingly have no sense of self other than self-in-relation, and without an external shaping force their bodies begin to break down into simpler forms, moving toward individual cells" (74). More concerning, Jodahs's ability to control the genetic changes he makes to itself and to others also depends on its proximity to objects of its desire, as Nikanj makes clear, "You've seen it yourself. With a potential mate—even a very unsuitable one-your control is flawless. Without a potential mate, you have no control. You were surprised when I told you you were losing your hair. You've been surprised by your body again and again. Yet nothing it does should surprise you. Nothing it does should be beyond your control” (607). In Naomi Jacob's assessment, “The construct ooloi's shape and scent, indeed its very existence, are dependent on the presence of others" (107). From one perspective, this selfin-relation identity positions the construct ooloi as both "the embodiment of Foucault's disciplined subject" and a representative of "Foucault's ideas about bio-power and its ability to constitute subjects through the normalizing power of dominant body images" (Vint 74; 75). The construct ooloi, who can engineer life, cannot imagine, or create, a form of self that is independent from internalized norms. From this perspective, Jodahs and its sibling, Aaor, represent the cyborg figures most bound within biopolitical systems.

However, there is a second way to read Jodah's lack of control of its ability as well as its unstable bodily form when outside the presence of potential mates. Jacobs suggests that the tendency to read ooloi constructs as the ultimate disciplined subject could be a reflection of the humanist tendency to represent the self "as endangered by the demands of relation with others" 
whereas "this posthuman self drifts 'toward a less complex form' in the absence of such relation" (108). Jodahs and its ooloi sibling represent a radical departure from humanist assumptions. They are not endangered by "relation with others;" they are instead strengthened by relationships and interdependence. In this, they depict the complex, contradicting, needy for connections cyborg figures Haraway envisions as ironically liberated. Their powers to create and engineer life depend on a profound connection to, and dependence on, others. I tend to agree with Vint's suggestion that, "The construct ooloi can ultimately be read as a positive image, both because they foreground the mutual construction of self and the social, and because their malleability suggests that we are not limited to the current cultural formation of our identities. We can imagine an elsewhere and work to materialize it" (76). The Oankali ooloi have solved humans' self-destructive tendency toward hierarchy, but their "imperative to recreate the sacred image of the same" has mutated in construct ooloi in unexpected ways. While the Oankali anticipated that construct ooloi would be powerful in unimaginable ways, as Jodahs remarks early on, "I would be the most extreme version of a construct—not just a mix of Human and Oankali characteristics, but able to use my body in ways that neither Human nor Oankai could. Synergy," they had not considered the ways a construct ooloi could be made more vulnerable by a merger with humans (549). As Jacob notes, "Both its powers and its vulnerabilities inform Butler's exploration of the posthuman body and subject...the price of its powers, then, is interdependence, to the point that an ooloi will die if one of its mates dies" (emphasis mine Jacobs 107). The posthuman cyborg Butler creates is incredibly powerful, but wielding its power requires it to recognize and embrace interconnectedness and interdependence.

Once Jodahs acquires human mates, its power and potentials are fully realized. Interestingly, its human mates come from a hidden resister enclave who, through inbreeding, is 
maintaining a semblance of pre-war human society. The humans suffer deformities, disease, and pain as a result of inbreeding, but they pride themselves on successfully resisting Oankali incursion. Until Jodahs meets his mates, a sibling pair traveling back to their village, Oankali are truly ignorant of the enclave's existence. Jodahs goes with his new mates to their village, where it tries to heal the damage caused by inbreeding in as many humans as it can. Like its brother, Akin, Jodahs's time with resister humans allows it to better understand the human resistance to gene trading. This village desperately wants a second chance to redeem humanity without genetic alteration. Though Jodahs understands this compulsion, it also knows that it is only a matter of time before the Oankali earth-ships, like Lo, will launch for the stars, destroying the planet. Jodahs slowly, and respectfully begins to coax the resisters into considering a trade partnership with the Oankali. When several members of the community show signs of agreeing, Jodahs presents a proposition to the Oankali to let it begin the first fully construct generation. The Oankali reluctantly agree, and the novel closes with an image of Jodahs planting a seed that will eventually grow a Lo-esque ship that will one day launch its construct brood toward the stars.

Jodahs's future fully-construct lineage represents the eutopian potential for a posthuman future assuaged of humanity's hierarchical tendencies as well as the Oankali's anti-utopian genetic essentialist dogma. Butler's ultimate posthuman image brings a human group so invested in "recreating the sacred image of the same" that they are literally suffering and dying from interbreeding, together with construct ooloi who involuntarily embody the image of the other's desire. The ending is not decidedly eutopian. We have seen Jodahs's destructive powers, and we now have little doubt that Akin's earlier observation that the Oankali "can make mistakes" is correct. The Oankali have repeatedly underestimated human will and have unintentionally 
created construct ooloi. The ingredients for dystopia are all here. But hope is here, too. The hope is in the unknowable. Unlike his mother Lilith and his brother Akin, Jodahs is a cyborg imbued with creative potential. While Lilith and Akin learn to leverage their cyborg qualities to negotiate small amounts of power within the Oankali power system, Jodahs can literally alter, design, create, and destroy life. It can write its own story and an origin story of a new people, a story without "pure" humans or "pure" Oankali, which is perhaps also a story "without end" (Haraway "A Cyborg" 150).

\section{Conclusion}

Butler crafts a complicated, messy, and contradicting tale of posthumanity in her Xenogenesis trilogy. Hope for a more equitable posthuman future is left to the merger of two fundamentally flawed species. Though the conclusion does gesture towards the possibility that a posthuman future can be a eutopian one in its final figure of a powerful cyborg - a cyborg whose hybridity and ability to create frees it from Oankali and human power structures and gives it the potential to craft a new way of life - the trilogy suggests that the road to eutopian possibility will be long and perilous, and eutopia is far from guaranteed. For Lilith and Akin, posthumanity isolates them from community and renders them vulnerable to violence and resentment from other humans. In the Oankali society, they perceive themselves to be tools, pawns, and experiments rather than sovereign individuals. Posthumanity marks their bodies as "other" and forces them into a liminal existence between Oankali and human worlds.

Initially, Jodahs's posthuman body similarly marks it as "other" and pushes it to the extremities of bare-life existence. However, what marks Jodahs as other ultimately gives it the power to create a relational system of interdependence and collaboration. Jodahs is capable of 
creating a social system that humans, and Oankali, literally cannot imagine, a truly posthuman and post-Oankali existence. It is possible that it can unintentionally produce a new type of power that is just as oppressive, coercive, and destructive as its ancestors. Its volatile powers bring to the surface the terror of an unimagined monstrous posthuamity. But it is also possible that it will find a way to incorporate the body and will, and diversity without hierarchy, into a new species that truly is best of the Oankali and the best of humanity. 


\section{Epilogue}

This is not a conclusion.

When I sat down to begin drafting the final piece of this project, I was surprised by a sudden and confounding case of writer's block. What is happening? The conclusion should be the easiest part? So, I did what any industrious student would do; I went to the library database and looked up our department's recently published dissertations to see how others have concluded their projects, projects that, like mine, undoubtedly consumed three-plus years of their authors' lives. They were wonderful conclusions that beautifully tied up loose ends and gestured towards future projects. Inspired, I opened a new document and went to work. Writer's block struck again. Somehow, this type of rehearsed closure feels wrong. My fingers ache to type something different. I can't find a thesis; I can't find a pithy summation that encapsulates three years of thought and revision, a polished paragraph that tells readers what it all means. So, this is not a conclusion. This is a very untidy story of a very messy process.

This project has come a long way. I began here, with a hypothesis, written as a thesis to a book list I hadn't yet read:

While this is not an exhaustive list of post-1980 dystopian novels that speculate the future of human reproductive processes, the above examples typify the two most common manifestations of disrupted childbirth processes in critical dystopias: state-controlled reproductive processes and the use of advanced reproductive technologies. In dystopian visions, both manifestations allow oppressive state systems to exercise control over citizens by controlling- 
disrupting, altering, restricting - female bodies. The consistent presence of these two reproductive themes in speculative fiction suggests that these texts are addressing burgeoning cultural anxieties about the relationships between 1) reproductive autonomy and political autonomy and 2) reproductive processes and conceptions/definitions of humanity.

No mention of cyborgs, or biopolitics, or posthuman possibilities. I still don't know what I meant by "disrupted childbirth processes."

The semester before I began drafting, the semester my prospective was due and my daughter was born, I worked in the writing studio as a graduate tutor. I remember working with a doctoral candidate finishing his dissertation in a STEM field. His dissertation proposed a hypothesis, and after completing his experiment, he concluded that his hypothesis was dead wrong. In his field, a doctoral candidate can publish a failed hypothesis and still graduate. His degree, conferred despite his acknowledgment that he was wrong, evidences his field's recognition that wrong answers have value. A dissertation can be wrong and still be valuable. What an intriguing idea.

I'm intensely proud of this project. I have worked hard to develop a defendable theoretical frame and to shape each chapter to fit within the parameters I have set. I have diligently tried to learn the ropes of academic writing while also maintaining a semblance of my own voice, the same voice that prompted my favorite undergrad professors to nudge me towards graduate studies in the first place. I'm still working to polish syntax and nuance analyses. I still have so much to learn about my field. Despite my perfectionist streak and my severe case of impostor syndrome, I am proud of this final product. Yet, lately, a quiet voice has been whispering in my ear, you might be wrong about all of this. 
Raffaella Baccolini and Tom Moylan open their collection on the critical-dystopian genre, Dark Horizons, with what has come to be my favorite scholarly meditation on the possibilities for critical-dystopian visions to inspire real-life material change. The chapter breaks sharply with western academic writing conventions and literary scholarship. It is not a thesisdriven argument; it does not conclude. Instead, the chapter is comprised of a series of private letters written between Ruth Levitas and Lucy Sargisson from July 17, 2001 to January 9, 2002. In them, the writers, who both "want the world to be changed," parse their ever-evolving and often-conflicting beliefs in the social power of utopian dreaming (13). Levitas, a self-described pessimist, grants that utopian thought remains a valuable mode of social critique, but doubts that "holding up a critical mirror to the present to expose its negative characteristics and effects" has the power to "catalyze change" (14). Initially, Sargisson agrees that utopian "desire is not enough," and neither is "holding up a mirror," but she fundamentally disagrees with Levitas's pessimism (17). Sargisson locates the catalyzing power of utopian visions in their ability to teach us to think differently about "alienation, duality, polarizations, competition, separation, and oppositional thinking" (17).

Their exchanges continue at a quick pace through July of 2001. Though both writers are clearly invested in the real-life stakes of utopian dreaming, these July letters primarily engage in theoretical discourses characteristic of academic culture. Then, a time lapse: October 30, "Dear Lucy...I almost believed, for a while, that there actually are transformative spaces of hope," but, "then came 11 September 2001" (24). For both writers, September 11 raises the stakes of their theoretical, academic debate. Both immediately shift focus from the possibilities to the perils of utopian thinking, reading the attack, and America's overwhelmingly reactionary response to it, as "powerful forces clashing over radically different versions of utopia" (24). Sargisson 
acknowledges that the attack deeply affected her scholarly assumptions about utopianism: "it's been a long time since I wrote my last letter because I got stuck" (25). Sargisson is quick to point out that she, like Levitas, has always recognized "the dark side of Utopia"; however, September 11 has pushed her to the edge of an unfamiliar ledge. Surprisingly, Sargisson's new pessimism inspires a renewed optimism in Levitas, a forced and determined optimism. Levitas fears that Sargisson has ventured into anti-utopian territory and she steps in to coax her friend off of the ledge. Levitas, the pessimist, closes the dialogue by insisting on the necessity of hope.

I suppose that readers could easily enough derive an implicit thesis from the exchange, something along the lines of the imperative of utopian dreams in dark times. In that, there isn't really anything remarkable about where the dialogue begins or ends. Weighing the possibilities of utopian thought against its perils has occupied utopian scholars for a long time. Further, their shock at the "banal fact that ordinary people are capable of horrific acts" suggests that they are both writing from positions of relative privilege (26). However, for me, the power of this exchange is not in where it ends up, but how it gets there. Despite the epistolary format, the exchange begins in characteristic academic fashion, with carefully crafted and supported thesisdriven arguments; however, a real world event interjects their formulaic point-counterpoint exchange and knocks their theoretical journey off course. The post-9/11 letters give readers a rare glimpse at what academic writing tries so hard to obscure - the ways our personal lives intersect with, inform, and challenge our academic work. Both writers' style and voice change in the months after the terrorist attack. Whereas the July letters demonstrate the scholars' mastery of the assertive academic tone, disciplined to edit arguments down to defendable, cohesive claims, the later letters cede confidence to uncertainty. Declarative speech gives way to a flood of "perhaps," "may be," “I do and I don't," "I think," "It's left me thinking—no, feeling—, “" “I 
hope." Levitas's final letter shows signs that she is moving towards regaining her earlier posture, but, for me, the heart of the exchange resides in the moments that both scholars "got stuck."

I was initially pulled to this project about reproductive justice and dystopia because, like Sargisson and Levitas, I want the world to change. I also love books. My personal goal upon entering a doctoral program was, and still is, to find ways to put academic study to the service of social justice activism. Like Sargisson, I gravitated to speculative fiction because of my belief that the process of reading about alternative worlds fundamentally changes how we think about our own world. I still believe this. I love these books precisely because they make me feel icky and invite me to investigate the ickiness—should I feel icky? What assumptions do I unwittingly hold that make me think this is icky? Speculative fiction has, time and time again, changed the way I think about the real world. And I believe in the central claim of this dissertation; these cyborg characters can help us begin the process of dreaming in eutopian dreams about a posthuman future. But the process of writing this dissertation has shaken my confidence in an underlying premise that is central to my reading of these characters, that the critical dystopian genre encourages us to better see the world as it already is. As I've been putting the finishing touches on my project, I've also been stifling the growing suspicion that, though these novels are not anti-utopian, dystopian stories are too easily co-opted by, and put to the service of, twentyfirst-century anti-utopian impulses. Like Sargisson and Levitas, my suspicion is not the result of reading academic scholarship or closely analyzing my primary texts. It is the result of a few surprising intersections between my personal life and my academic work.

Most obviously, I became a mother during this process. The polished surface of my dissertation doesn't include footnotes of a miscarriage, followed by the birth of my son, and then the birth of my daughter. Our field demands that we erect superficial boundaries between our 
personal lives and our scholarship, especially if those personal lives include children. Until now, I've faithfully complied. But the truth is that my children's presence and influence are woven into every page of these chapters. I drafted chapter 2 , about the double bind of motherhood and citizenship, while deep in the throes of paralyzing postpartum anxiety. My daughter wasn't sleeping, so neither was I. We were both suffering from my recurring bouts of mastitis and thrush. I suffered nine excruciating months of trying to overcome an illness in order to be a good, "normal" mother and a good, "normal" grad student. Early drafts of chapter two attest to this. The first is a sprawling, fragmented, repetitive, $60+$ page monstrosity with no thesis. I'm still not happy with the final version of that chapter, and I still fight off a crippling sense of inadequacy and failure when I revisit it. I don't know if it's my argument that I'm not satisfied with or if the memories of struggling to get something on paper are still too raw. I'm not sure I'll ever read The Handmaid's Tale again. Luckily, I was able to find my way back. The anxiety subsided, my daughter learned to sleep, and I thoroughly enjoyed drafting chapters 3 and 4 . They provided a welcome reprieve from diapers, nap schedules, and Mickey Mouse Clubhouse.

The second real-life intrusion came in two parts. The first manifested in the shape of case studies, memoirs, and history lessons of twentieth- and twenty-first-century systematic deprivations of reproductive freedoms. Though I paint in broad strokes in the dissertation, glossing eugenics programs and fetal motherhood, the voices of the countless women who have been sterilized, imprisoned for miscarrying or suffering stillbirths, legally prosecuted for seeking an abortion, or so trapped by forces in their lives that infanticide seemed to be their only viable option, didn't make the final cut in my arguments. However, I carry these voices with me. I hear them constantly. I had vague ideas about reproductive injustices before I began this project, but it wasn't until I read the work of Jeanne Flavin and Catherine Mills, and read about the injustices 
that fuel SisterSong activism, or began paying attention to the plights of incarcerated bodies, that I realized just how much is elided by pro-choice/pro-life rhetoric.

Part two came a year ago, when I joined one book club, held in a women's prison, and then helped begin a second one in a men's prison. Much like my ideas of reproductive injustices, I thought I had a pretty good grasp on the impacts of systemic injustices in our legal system. I didn't. Not really. I knew a lot of statistics. I had read a lot of really good books. Now I have faces. I have friends. I've stood in their incomprehensibly small cells. I've read their poetry. I've seen them battle against hopelessness with a steadfastness and a courage that I'm not sure I could maintain. I've seen them ache for daughters they cannot touch; mourn for sons who died while they were locked up. Getting to know these men and women has profoundly shaken my view of the world, and this includes my approach to scholarship. I enjoyed every second of graduate seminars. I love grappling with theories and talking in the abstract, but the incarcerated men I have come to know insist on finding real, tangible, and meaningful solutions. Their fervor for change is contagious. Like Levitas, I am restless and growing impatient with mirrors that can only reflect.

These two intrusions have revealed to me the real-life dystopias so many people are currently living in, dystopias that are hidden to most, and, in many cases, just as bad, if not worse, than the fictional worlds in my treasured books. And then, just as I began trying to separate these dystopian intrusions from my eutopian dissertation thesis, someone asked me a question that has been haunting me for months. In November, I gave a presentation of chapters three and four. The presentation went well and yielded an energetic Q \& A session during which a professor I deeply admire asked a half-formed question about the possibility that these nightmarish hellscapes inadvertently mask how bad things really are now. I immediately thought 
of Ellen Painter Dollar's memoir, No Easy Choice, another voice that didn't make it into the edited version of my dissertation chapters. Her memoir recounts the unexpected repercussions she experienced—financial, emotional, and physical—from electing IVF in order to use PGD to prevent giving birth to children who would suffer from osteogenesis imperfecta, the brittle bones disease that has crippled her own body. I thought of similar stories I have encountered during this process, stories of people who found themselves bound in surprising ways by ARTs that were supposed to increase their reproductive choices.

And then, weeks later, Trump was elected. Among the daily barrage of ever-moreterrifying headlines are ones like these: "Childbearing Beliefs Were Best Predictor of Trump Support"; "Oklahoma House Advances Bill to Require Men's Permission for Abortions”; and in Tennessee, "Proposed Bill Deems Children Born Through Artificial Insemination Illegitimate Children." Two days ago, this one: “Trump Tells Planned Parenthood Its Funding Can Stay if Abortion Goes."

Perhaps not surprisingly, many self-identified liberals who fear that Trump's inauguration sets a course towards dark horizons are re-reading Orwell, Bradbury, and Atwood. Sales of both classic and critical dystopian novels have soared since January. One would think that someone who has dedicated so much time and energy to extolling the eutopian possibilities imbedded in dystopian visions would celebrate this trend, but something about the sudden popularity of dystopia is bugging me. I'm starting to suspect that this trend is a symptom of deep-seated anti-utopian tendencies masked by the monikers of "liberal" and "progressive." While it is easy to identify the anti-utopian core of "Make America Great Again" rhetoric, I have a growing suspicion that the impulse to fill Amazon shopping carts with dystopian novels derives 
from a similar inability to imagine a better future, a new way. Sales spikes of Sinclair's It Can't Happen Here are driven by the fear that yes it could...it could get worse.

Yes, things could get worse, and fighting movement in the wrong direction is priority number one. However, as today's real-life world powers seem hell bent on ushering in the horrors of dystopian fiction, I can't seem to shake a growing insistence that we must demand more than "not worse," we must find ways to move towards "better." In other words, I suspect that warning against the possibility of a future dystopia masks, rather than reveals, the dystopia that is here. My fear is that the momentum to resist will too quickly dissipate if/when turning tides return us to a status quo we've been complacent with for far too long. I'm afraid that we may too quickly celebrate the deaths of absurd state bills proposing draconian impositions to reproductive rights, and relax into the relief that we've dodged a bullet when said bills don't pass. I'm afraid that our fear of an imminent dystopia will make the injustices of right now more tolerable down the road if we are able to "come back" to a pre-Trump "normal." Of course, I'm far from the first to express such fears. The most vulnerable in our society have long been working to expose the uncanny similarities between conservative and liberal social and political platforms.

This growing fear of mine marks a moment of divergence with the body of scholarship that, like Levitas, credits critical dystopias as useful critical mirrors. I'm no longer sure that $21^{\text {st }}$ century Americans will read The Handmaid's Tale and gain a better understanding of current plights for reproductive justice that extend beyond access to contraceptives and safe, legal abortions. I'm not confident that my dear friend, who took out a second mortgage on her home to pay for a few more rounds of IVF, would read The Windup Girl and better understand the bioeconomy driving the costs of already-existing ARTs. To be clear, I do not think these novels 
are promoting anti-utopian visions (though they have been criticized by others for doing just that). I do, however, fear that in a post-utopian environment, they are too easily co-opted by antiutopian agendas. I don't know where this leaves my dissertation thesis, but I feel that confronting these doubts are an important part of the process of utopian dreaming.

In an old episode of South Park, Cartman, Stan, and Kyle happen upon a group of underpants gnomes. The underpants gnomes are hopeful entrepreneurs, utopian dreamers, who steal underpants from humans' drawers. When the boys ask the gnomes the obvious question, why do they steal underpants, the gnome spokesperson answers, "phase one, collect underpants." The boys ask, "so, what's phase two?" The gnome doesn't have an answer. Instead, he shows the boys the gnomes' business plan: "phase one: collect underpants. Phase three: profit." The gnomes don't have a phase two.

Overtly eutopian visions are often criticized as too didactic and flawed by the author's blindness to her own ideologies. In general, I agree. And yet, I too often hear the underpants gnomes' glaring omission of phase two in our cultural, and scholarly, propensities to link phase one, "point out the problems of today's world" with phase three, "make society better." Perhaps an off-page eutopian glimmer isn't potent enough after all. While these glimmers can give us hope that phase three is possible, they might not be enough to help a culture mired in postutopian limitations to envision a productive phase two.

This isn't a conclusion. It's a glimpse into my story of the messy, muddled, and everevolving process of trying to find a viable phase two. This is the pessimistic underbelly of an optimistic project, the fragmented and incomplete thoughts edited out of a superficially polished product. I know this is an unconventional way to end a dissertation, but it somehow feels right to wrap-up a dissertation about critical dystopian fiction by refusing closure. If my epilogue has a 
thesis, it is this: writing our way out of the darkness will eventually require forming a concrete and viable phase two. But this epilogue isn't really about the thesis. It's about the process. And what a journey this has been 


\section{Bibliography}

Agamben, Georgio. Homo Sacer. Tr. Daniel Heller-Roazen. Stanford, CA: Stanford University Press, 1998. Print.

---State of Exception. Tr. Kevin Attell. Chicago: University of Chicago Press, 2005.

Auerbach, Nina. Our Vampires, Ourselves. Chicago: University of Chicago Press, 1995.

--- State of Exception. Tr. Kevin Attell. Chicago: University of Chicago Press, 2005.

Atwood, Margaret. "Haunted by The Handmaid's Tale." The Guardian. 20 January 2012. Web.

---In Other Worlds. Toronto: Doubleday, 2011. Print.

---The Handmaid's Tale. NY: Anchor Books, 1998. Print.

Baccolini, Raffaella and Tom Moylan, eds. Dark Horizons: Science Fiction and the Dystopian Imagination. New York: Routledge, 2003.

--- "Introduction.” Raffaella Baccolini and Tom Moylan.1-12.

Baccolini, Raffaella. "Gender and Genre in the Feminist Critical Dystopias of Katherine Burdekin, Margaret Atwood, and Octavia Butler." Future Females, The Next Generation. Ed. Marleen S. Barr. Lanham, MD: Rowman and Littlefield, 2000. 13-34. Print.

Bacigalupi, Paolo. The Windup Girl. San Francisco: Night Shade Books, 2009.

Balsamo, Anne. "Reading Cyborgs Writing Feminism.” Wolmark 145-156.

Barlett, Donald L., and James B. Steele. Monsanto's Harvest of Fear. 50 Vol. New York: Conde Nast Publications, Inc, 2008. Web.

Belk, Nolan. "The Certainty of the Flesh: Octavia Butler's Use of the Erotic in the Xenogenesis Trilogy." Utopian Studies 19.3 (2008): 369-389. Web.

Bendle, Mervyn F. "Teleportation, Cyborgs and the Posthuman Ideology." Social Semiotics 12.1 (2002): 45-62. Academic Search Complete. Web. 
Berlant, Lauren. The Queen of America Goes to Washington City: Essays on Sex and Citizenship. Durham, NC: Duke University Press, 1997. Print.

Black, Edwin. War Against the Weak: Eugenics and America's Campaign to Create a Master Race. NY: Four Walls Eight Windows, 2003. Print.

Booker, Keith M. The Post-Utopian Imagination: American Culture in the Long 1950s.

Westport, CT: Greenwood Press, 2002. Print.

Bradford, Clare, Kerry Mallan, John Stephens, and Robyn McCallum. New World Orders in Contemporary Children's Literature. Hampshire and NY: Palgrave Macmillan, 2008. Print. 105-129.

Braid, Christina. "Contemplating and Contesting Violence in Dystopia: Violence in Octavia Butler's Xenogenesis Trilogy.” Contemporary Justice Review 9.1 (2006): 47-65. Web. Bruiger, Dan. Second Nature: The Man-made World of Idealism, Technology and Power.

Victoria, B.C.: Trafford Publishing, 2006. Print.

Butler, Octavia E. Bloodchild and Other Stories. NY: Seven Stories Press, 1996. Print.

---Lilith's Brood. NY: Grand Central Publishing, 2000. Print.

---“Interview with Octavia Butler.”Interviewd by Joshunda Sanders. In Motion Magazine, 14 March 2014. Inmotionmagazine.com. Web.

Caidin, Martin. Cyborg. NY: Warner Books, 1972. Print.

Campbell, Timothy C. Improper Life. Minneapolis, MN: University of Minnesota Press, 2011. Print.

Cavalcanti, Idlney. "Utopias of/f Language in Contemporary Feminist Dystopias." Utopian Studies 11.2 (2000): 152-80. Web. 
CDC. “2014 Assisted Reproductive Technology National Summary Report.” The Centers for Disease Control and Prevention, October 2016. cdc.gov. Web.

Clynes, Manfred E. and Nathan S. Kline. "Cyborgs and Space.” Astronautics (September 1960): 26-7; 74-76. Web.

“CNN Reagan Library Debate: Later Debate Full Transcript.” CNN. Cable News Network. 16 Sept. 2016. Web.

Currell, Susan and Christina Cogdell. Popular Eugenics: National Efficiency and American Mass Culture in the 1930s. Athens, OH: Ohio University Press, 2006. Print.

Curtis, Claire P. 'Utopian Possibilities: Disability, Norms, and Eugenics in Octavia Butler's Xenogenesis.” Journal of Literary \& Cultural Disability Studies 9.1 (2015): 19-33. Web.

Davis-Floyd, Robbie and Joseph Dumit. Eds. Cyborg Baby. NY: Routledge, 1998. Print.

Delegard, Kristen Marie. Battling Miss Bolsheviki: The Origins of Female Conservatism in the United States. Philadelphia, PA: University of Pennsylvania Press, 2012.

Diamond v. Chakrabarty. Supreme Court. 16 June 1980. Justia.com. https://supreme.justia.com/cases/federal/us/447/303/case.html Web.

Díaz, Junot. “Apocalypse: What Disasters Reveal.” Boston Review. 1 May 2011. Bostonreview.net

Dollar, Ellen Painter. No Easy Choice: A Story of Disability, Parenthood, and Faith in an Age of Advanced Reproduction. Louisville, KY: Westminster John Knox Press, 2012. Print.

Edelson, Edward. “Test Tube Birth: a Blessed Event?” Daily News, 27 July 1978, p. 3.

Eig, Jonathan. The Birth of the Pill: How Four Crusaders Reinvented Sex and Launched a Revolution. NY: W.W. Norton \& Company, 2014. Print. 
Feuer, Lois. "The Calculus of Love and Nightmare: The Handmaid's Tale and the Dystopian Tradition." Critique 38.2 (1997): 83-95. Web.

Flavin, Jeanne. Our Bodies, Our Crimes: The Policing of Women's Reproduction in America. New York: New York University Press, 2009. Print.

Foucault, Michel. The Birth of Bio-Politics. Tr. Graham Burchell. Ed. Michel Senellart. New York: Palgrave MacMillan, 2008. Print.

---“Docile Bodies.” Discipline and Punish. Tr. Alan Sheridan. NY: Random House, 1995. Print. 135-169. Print.

--- Society Must Be Defended. Tr. David Macey. Ed. Arnold I. Davidson. New York: Picador, 2003. Print.

Fukuyama, Francis. Our Posthuman Future. NY: Picador, 2002. Print.

Goss, Theodora and John Paul Riquelme. "From Superhuman to Posthuman: The Gothic Technological Imaginary in Mary Shelley's Frankenstein and Octavia Butler's Xenogeneis." Modern Fiction Studies 53.3 (2007): 434-459. Project Muse. Web.

Gray, Chris Hables. Cyborg Citizen. NY: Routledge, 2001. Print.

---Postmodern War. NY: The Guilford Press, 1997. Print.

Gross, Melissa. "The Giver And Shade's Children : Future Views Of Child Abandonment And Murder." Children's Literature In Education 30.2 (1999): 103-117. Education Research Complete. Web.

Grosz, Elizabeth. Volatile Bodies: Toward a Corporeal Feminism. Bloomington, IN: Indiana University Press, 1994. Print.

Hageman, Andrew. "The Challenge of Imagining Ecological Futures: Paolo Bacigalupi’s The Windup Girl." Science Fiction Studies 39 (2012): 283-303. Web. 
Hanson, Carter F. “The Utopian Function of Memory in Lois Lowry's The Giver.” Extrapolation 50.1 (2009): 45-60. Web.

Haraway, Donna. "Cyborgs and Symbionts: Living Together in the New World Order." The Cyborg Handbook. Chris Hables Gray. NY: Routledge, 1995. Print. xi-xx

---Simians, Cyborgs, and Women: The Reinvention of Nature. New York: Routledge, 1991. Print.

---“A Cyborg Manifesto.” Simians, Cyborgs, and Women. 149-182.

---. "The Biopolitics of Postmodern Bodies: Constitutions of Self in Immune System Discourse." Simians, Cyborgs, and Women. 203-230.

---. Staying with the Trouble: Making Kin in the Chthulucene. Durham, NC: Duke University Press, 2016. Print.

Hayles, Katherine. How We Became Post-Human. Chicago: The University of Chicago Press, 1999. Print.

Henig, Robin Marantz. Pandora's Baby. Boston and NY: Houghton Mifflin, 2004. Print.

Hughes, James. Citizen Cyborg. Cambridge, MA: Westview Press, 2004. Print.

Hull, Gordon. "Biopolitics Is Not (Primarily) About Life: On Biopolitics, Neoliberalism, and Families." The Journal of Speculative Philosophy 27.3 (2013): 322-335. Web.

Jacobs, Naomi. "Posthuman Bodies and Agency in Octavia Butler's Xenogenesis." Dark Horizons. Eds. Baccolini and Moylan. 91-112. Print.

Jameson, Fredric. Archaeologies of the Future: The Desire Called Utopia and Other Science Fictions. New York: Verso, 2005. Print.

---"Postmodernism and Consumer Society." Postmodern Culture. Ed. Hal Foster. London: Pluto Press, 1985. 111-25. PDF 
---Postmodernism, or, The Cultural Logic of Late Capitalism. Durham, NC: Duke University Press, 1991. Print.

Jesser, Nancy. "Blood, Genes and Gender in Octavia Butler's Kindred and Dawn." Extrapolation 43.1 (2002): 36-61. Web.

Kirkup, Gill, Linda Janes, Kathryn Woodward, and Fiona Hovenden, eds. The Gendered Cyborg: A Reader. London and New York: Routledge, 2000. Print.

---. “Introduction to Part One." Kirkup, Janes, Woodward, and Hovenden 3-10.

Kline, Wendy. Building a Better Race: Gender, Sexuality, and Eugenics from the Turn of the Century to the Baby Boom. Berkeley and Los Angeles, CA: University of California Press, 2001. Print.

Latham, Don. "Childhood Under Siege: Lois Lowry's Number the Stars and The Giver." The Lion and the Unicorn 26.1 (2002): 1-15. Project Muse 3 Dec 2015. Web.

---. "Discipline and Its Discontents: A Foucauldian Reading of The Giver" Children's Literature 32 (2004): 134-151. Project Muse 10 May 2015. Web.

Lea, Susan G. "Seeing Beyond Sameness: Using The Giver to Challenge Colorblind Ideology." Children's Literature in Education 37.1 (2006): 51-67. EBSCOhost. Web.

Lehman, Barbara A., and Patricia R. Crook. "Doubletalk: A Literary Pairing Of The Giver And We Are All In The Dumps With Jack And Guy." Children's Literature In Education 29.2 (1998): 69-78. Education Research Complete. Web.

Lemke, Thomas. Biopolitics: An Advanced Introduction. Tr. Eric Frederick Trump. NY: New York University Press, 2011. Print.

Lemm, Vanessa and Miguel Vatter. Eds. The Government of Life: Foucault, Biopolitics, and Neoliberalism. NY: Fordham University Press, 2014. Print. 
Levitas. Ruth. Utopia as Method: The Imaginary Reconstitution of Society. New York: Palgrave MacMillan, 2013. Print.

Levy, Michael M. “Lois Lowry’s The Giver: Interrupted Bildungsroman or Ambiguous Dystopia?" Foundation 70 (1997): 50-56. Web.

Little, Judith A. Feminist Philosophy and Science Fiction: Utopias and Dystopias. Amherst, NY: Prometheus Books, 2007. Print.

Lowry, Lois. The Giver. NY: Random House, 1993. Print.

Mayer, Petra. "Margaret Atwood's 'The Handmaid's Tale' Soars to Top of Amazon Bestseller List.” All Things Considered. NPR.org. 7 Feb. 2017. Web.

McClintock, Anne. "Family Feuds: Gender, Nationalism and the Family." Feminist Review 40 (1993): 61-80. Web.

Michael, Magali Cornier. Feminism and the Postmodern Impulse: Post-World War II Fiction. Albany, NY: State University of New York Press, 1996. Print.

Michaels, Walter Benn. "Political Science Fictions.” New Literary History 31 (2000): 649-64. Web.

Miller, Jim. “Post-Apocalyptic Hoping: Octavia Butler's Dystopian/Utopian Vision.” Science Fiction Studies 25.2 (1998): 336-360. JSTOR. Web.

Mills, Catherine. Futures of Reproduction: Bioethics and Biopolitics. London: Springer, 2011. PDF.

Miringoff, Marque-Luisa. The Social Costs of Genetic Welfare. Brunswick, NJ: Rutgers University Press, 1991. Print.

Morton, Stephen and Stephen Bygrave, eds. Foucault in an Age of Terror: Essays on Biopolitics and the Defense of Society. New York: Palgrave MacMillan, 2008. Print. 
Moylan, Tom. Scraps of the Untainted Sky: Science Fiction, Utopia, Dystopia. Boulder, CO: Westview Press, 2000. Print.

Mundy, Liza. Everything Conceivable. NY: Alred A. Knopf, 2007. Print.

Murphy, Michelle. Seizing the Means of Reproduction: Entanglements of Feminism, Health, and Technoscience. Durham, NC: Duke University Press, 2012. Print.

Nanda, Aparajita. "Power, Politics, and Domestic Desire in Ocavia Butler's Lilith's Brood." Callaloo 36.3 (2013): 773-788. Project Muse. Web.

Neuman, Shirley. "Just a Backlash: Margaret Atwood, Feminism, and The Handmaid's Tale." University of Toronto Quarterly 75.3 (2006): 857-68. Web.

Nickerson, Michelle M. Mothers of Conservatism: Women and the Postwar Right. Princeton, NJ: Princeton University Press, 2012. Print.

Nilsson, Jakob and Sven-Olov Wallensten, eds. Foucault, Biopolitcs, and Governmentality. Stockholm: Södertörn University Press, 2013. PDF.

Obourn, Megan. “Octavia Butler's Disabled Futures.” Contemporary Literature 54.1 (2013): 109-138. Project Muse. Web.

Peppers, Cathy. "Dialogic Origins and Alien Identities in Butler's Xenogenesis.” Science Fiction Studies. 22.1 (1995): 47-62. JSTOR. Web.

Plant, Rebecca Jo. Mom: The Transformation of Motherhood in Modern America. Chicago: University of Chicago Press, 2010. Print.

Pintel-Ginsberg, Idit. "Lilith.” Encyclopedia of Jewish Folklore and Traditions. Ed. Haya BarItzhak and Raphael Patai. Routledge, 2013. Credo Reference. Web.

Ragoné, Heléna and Rance Winddance Twine, Eds. Ideologies and Technologies of Motherhood: Race, Class, Sexuality, Nationalism. NY: Routledge, 2000. Print. 
"Reproductive Justice." SisterSong: Women of Color Reproductive Justice Collective. sistersong.net., n.d. Web.

Rogin, Michael. Ronald Reagan the Movie. Oakland, CA: University of California Press, 1988. Print.

Rosen, Christine. Preaching Eugenics: Religious Leaders and the American Eugenics Movement. NY: Oxford University Press, 2004. Print.

Rymph, Catherine E. Republican Women: Feminism and the Conservatism from Suffrage through the Rise of the new Right. Chapel Hill, NC: The University of North Carolina Press, 2006. Print.

Sargent, Lyman Tower. “Three Faces of Utopianism Revisited.” Utopian Studies 5.1 (1994): 137. Web.

Selisker, Scott. “'Stutter-Stop Flash-Bulb Strange': GMOs and the Aesthetics of Scale in Paolo Bacigalupi’s The Windup Girl." Science Fiction Studies 42 (2015): 500-518. Web.

Sheckels, Theodore F. The Political in Margaret Atwood's Fiction. Burlington, VT: Ashgate, 2012. Print.

Smith, Rachel Greenwald. "Ecology Beyond Ecology: Life After the Accident in Octavia Butler's Xenogenesis Trilogy.” Modern Fiction Studies 55.3 (2009): 545-565. Project Muse. Web.

Stableford, Brian. "Cyborgs." The Encyclopedia of Science Fiction. Eds. John Clute and Peter Nicholls. NY: St. Martin's Griffin, 1995. Print. 290-91.

Stern, Alexandra Minna. Eugenic Nation: Faults and Frontiers of Better Breeding in Modern America. Berkley, CA: University of California Press, 2005. Print. 
Stewart, Susan Louise. "A Return to Normal: Lois Lowry's The Giver.” The Lion and the Unicorn 31.1 (2007): 21-35. Project Muse 31 Jan 2012. Web.

Stickgold-Sarah, Jessie. “'Your Children Will Know Us, You Never Will': The Pessimistic Utopia of Octavia Butler’s Xenogenesis Trilogy.” Extrapolation 51.3 (2010): 414-430. Web.

Suvin, Darko. Defined by a Hollow: Essays on Utopia, Science Fiction, and Political Epistemology. Bern, Switzerland: Peter Lang AG, International Academic Publishers, 2010. Print.

---Metamorphoses of science fiction: On the poetics and history of a literary genre. New Haven, Connecticut: Yale University Press, 1979. Print.

---“Theses on Dystopia 2001.” Raffaella Baccolini and Tom Moylan.187-202.

Takeshita, Chikako. The Global Biopolitics of the IUD: How Science Constructs Contraceptive Users and Women's Bodies. Cambridge, MA: The MIT Press, 2012. PDF.

“The Rise of Dystopian Art.” The Stream-Al Jazeera English. AlJazeera.com. 14 Feb. 2017. Web.

Vint, Sherryl. Bodies of Tomorrow: Technology, Subjectivity, Science Fiction. Toronto: University of Toronto, 2007. Print.

---“Octavia Butler: Be(com)ing Human.” Bodies of Tomorrow. 56-78. Print.

--- "Introduction: Science Fiction And Biopolitics." Science Fiction Film \& Television 4.2 (2011): 161-172. Film \& Television Literature Index with Full Text. Web.

White, Eric. "The Erotics of Becoming: Xenogenesis and 'The Thing."” Science Fiction Studies 20.3 (1993): 394-408. JSTOR. Web. 
Wolmark, Jenny. Aliens and Others: Science Fiction, Feminism, and Postmodernism. Iowa City, IA: University of Iowa Press, 1994. Print.

--- Ed. Cybersexualities: A Reader on Feminist Theory, Cyborgs, and Cyberspace. Edinburgh, UK: Edinburgh University Press, 1992. Print.

Woodward, Kathleen. "From Virtual Cyborgs to Biological Time Bombs: Technocriticism and the Material Body." Wolmark 280-294.

Yaszek, Lisa. Galactic Suburbia. Columbus, OH: The Ohio State University Press, 2008. Print.

Zaki, Hoda M. "Utopia, Dystopia, and Ideology in the Science fiction of Octavia Butler." Science Fiction Studies 17.2 (1990): 239-51. Web. 